Portland State University

PDXScholar

Winter 3-19-2014

\title{
Explaining Ballot Initiative Contest Outcomes in California, Oregon, and Washington
}

Hans Daniel Stroo

Portland State University

Follow this and additional works at: https://pdxscholar.library.pdx.edu/open_access_etds

Part of the Other Political Science Commons, and the Political Theory Commons Let us know how access to this document benefits you.

\section{Recommended Citation}

Stroo, Hans Daniel, "Explaining Ballot Initiative Contest Outcomes in California, Oregon, and Washington" (2014). Dissertations and Theses. Paper 1649.

https://doi.org/10.15760/etd.1648

This Thesis is brought to you for free and open access. It has been accepted for inclusion in Dissertations and Theses by an authorized administrator of PDXScholar. Please contact us if we can make this document more accessible: pdxscholar@pdx.edu. 


\title{
Explaining Ballot Initiative Contest Outcomes \\ in California, Oregon, and Washington
}

\section{by}

Hans Daniel Stroo

A thesis submitted in partial fulfillment of the requirements for the degree of

\author{
Master of Science \\ in \\ Political Science
}

\author{
Thesis Committee: \\ Kim M. Williams, Chair \\ Richard Clucas \\ Joseph Lampert
}

Portalnd State University 2014 


\begin{abstract}
What explains the outcomes of ballot initiative contests? What factors determine the passage or rejection of an initiative? This paper describes and evaluates three approaches to explaining ballot initiative contest outcomes. The first approach involves using the expenditures of Yes and No campaigns as the causal factor in explaining why passage or defeat is the respective outcome of a given contest. The second explanatory approach emphasizes the logic of collective action problems. The third approach incorporates the larger constellation of policymaking institutions in which each ballot initiative process exists. Specifically, in what ways is the process shaped by the larger system of partisan attachments that structures electoral politics?

This paper contains a set of three analyses which speak to each of the three respective explanatory approaches to explaining initiative contest outcomes. The results provide evidence of the importance of a contest's early competitive dynamic in determining the amount of resources made available for a campaign to spend. Left unaccounted for, this strategic financing of initiatives distorts estimates of the effectiveness of spending.
\end{abstract}

The second analysis, inspired by insights into collective action problems, finds the initiative arena to be a policymaking site where there is a competitive advantage for broadly diffused interests, especially when they challenge other broad interests. Moreover, broad-based Yes groups achieved relatively high passage rates with relatively low levels of campaigns expenditures. 
Finally, the third analysis provides evidence of a consistently high level of correlation between Yes voting and alignment with a particular party. The lowest levels of correlation were still fairly high from a measured social science perspective. In many instances, county-level party attachment mapped almost seamlessly over initiative decision making. This suggests that ballot initiatives politics do not operate outside party politics, as has been suggested in the past. 


\section{Acknowledgments}

The most gratitude is absolutely owed to Cynthia and Eric Stroo, my parents. My advisor, Professor Kimberly M. Williams helped guide my project from start to finish, and I thank her. Also, I owe tremendous thanks for the generous assistance and

encouragement of Doctors Anne Campbell, Bruce Gilley, Todd Donovan, Hežky Babbages, and David Newland. 


\section{Table of Contents}

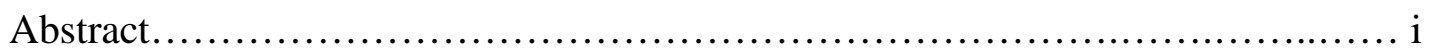

Acknowledgements.......................................................... ii

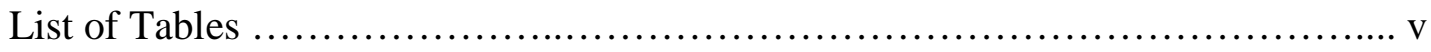

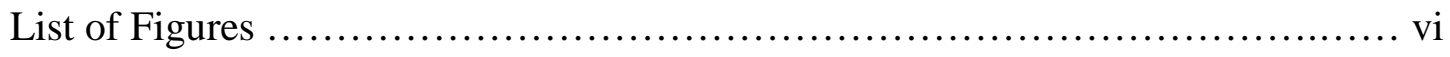

\section{Chapter 1}

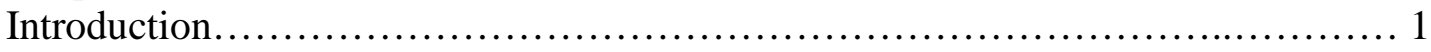

Chapter 2

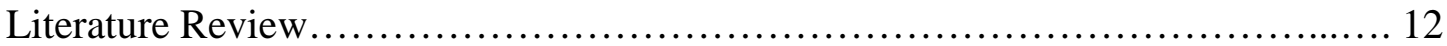

Chapter 3

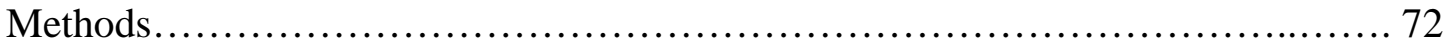

Chapter 4

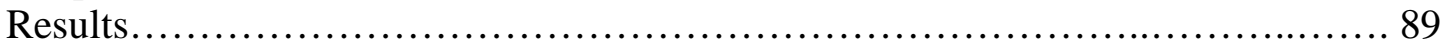

Chapter 5

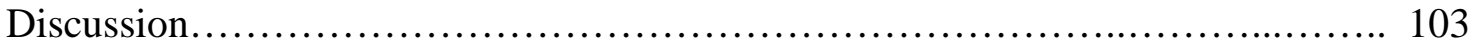

References......................................................................... 119

Appendices

Appendix A

Design \#1 Data......................................................... 126

Appendix B

Design \#2 Data....................................................... 135

Appendix C

Design \#3 Data........................................................... 139 


\section{List of Tables}

Table $1:$................................................................. 5

Three approaches to explaining initiative contest outcomes

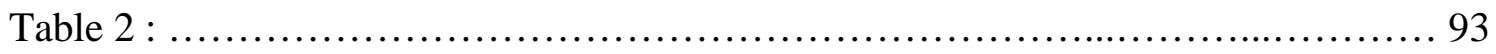

Mean Yes vote percentage, by contest type

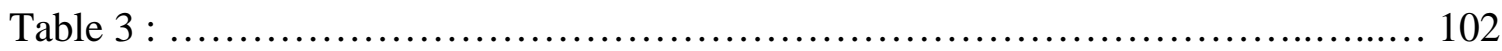

Coefficients of correlations between a county's Yes voting on a ballot measure and its level of attachment to the Democratic Party 


\section{List of Figures}

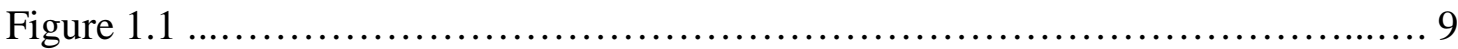

Generic causal-mechanistic story

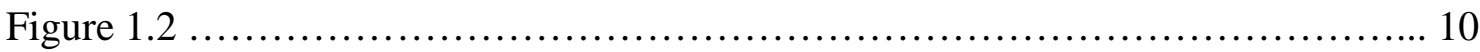

Structure for this paper's explanations of initiative contest outcomes

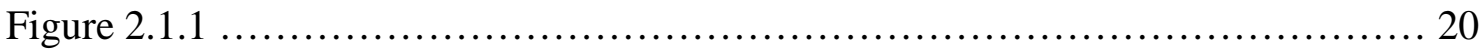

Endogeneity of candidate campaign spending to identity of Election Day winner

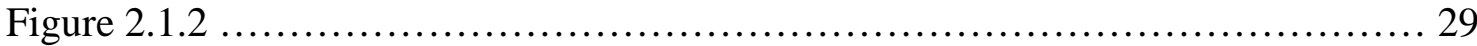

Endogeneity problem plaguing estimates of the effect of spending upon passage rates

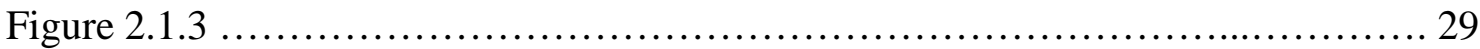

Recurrent strategic situation where narrow groups spend large on initiatives with slim chances of passing

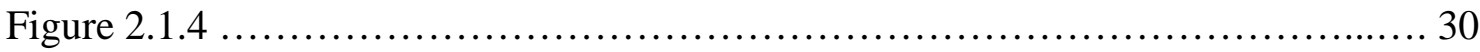

Recurrent situation where broad groups spend small on initiatives with large early majorities for passage

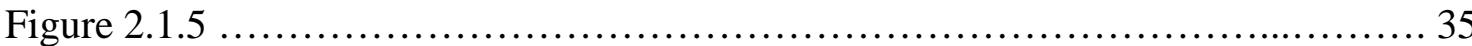

Bowler and Donovan's explanation of asymmetric effects, risk-averse voters, and status quo bias in the initiative process

Figure 2.2.1

Wilson's typology of policies and political situations

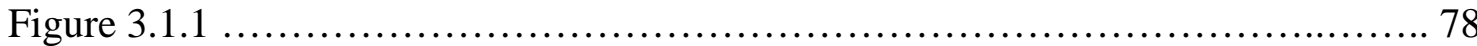

5-point competitive dynamic scale for initiative contests

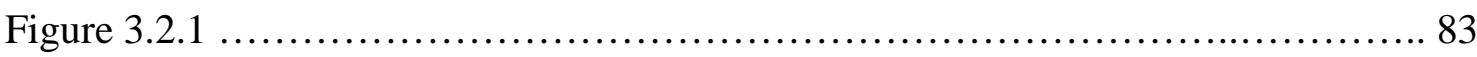

"A Simple Classification of Initiative Contests" using the Wilson typology

Figure 4.1.1

Distribution of initiative opinion polls by type

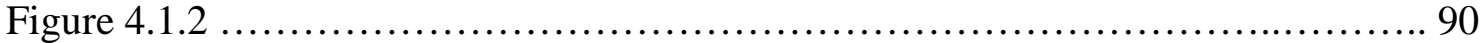

Distribution of polls by condensed competitive typing 


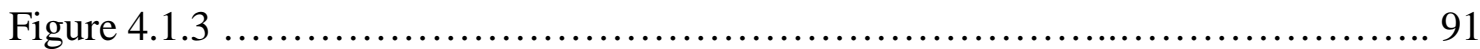

Distribution of competitive dynamic types within a sample of initiative contests

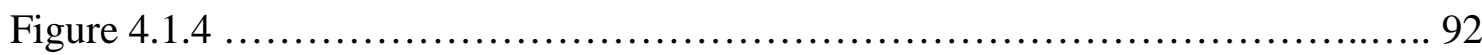

Distribution of occurrences of initiative contests within the condensed competitive dynamic categories

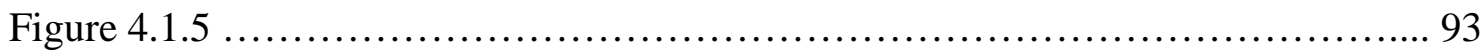

Passage rate distribution across contest types

Figure 4.1.6

Distribution of passage rates across condensed categories of competitive dynamic

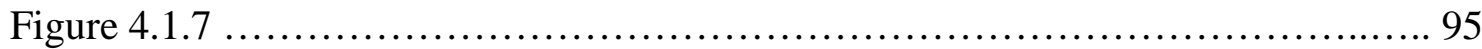

Mean Yes spending strength of initiative contests typed into condensed competitive dynamic categories

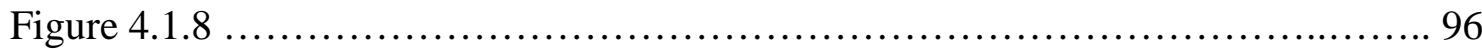

Mean No spending strength of initiative contests typed by condensed competitive dynamic categories

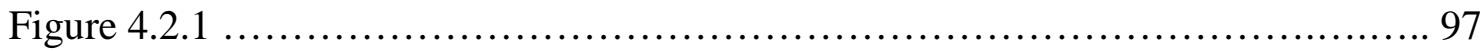

Wilson types - total occurrences and percentages of sample

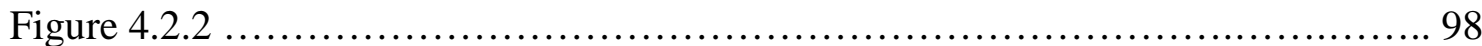

Initiative passage distribution across Wilson-typed contests

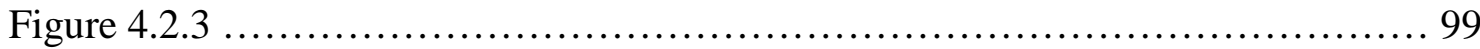

Distribution of mean Yes-voting across Wilson-typed contest

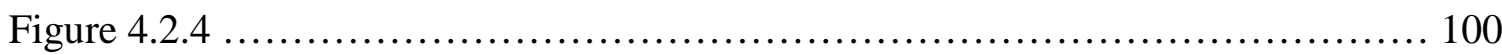

Mean No spending strength distribution of Wilson typed-contests

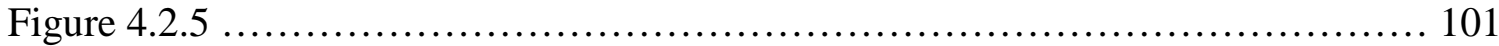

Mean No spending strength distribution of Wilson typed-contests

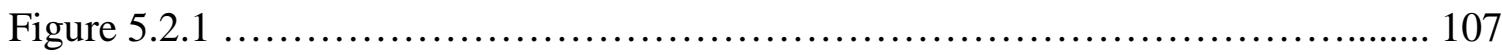

Relationship between majoritarian initiative contests, spending, and passage rates

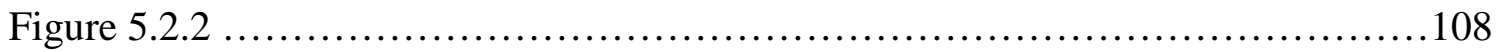

Relationship between narrow-narrow contests, spending, and passage rates 
Figure 5.3.1

109

Relationship between county-level Democratic Party affiliations and voting on

Oregon's Ballot Measure 5 (2000)

Figure 5.3.2

110

Relationship between county-level Democratic Party affiliations and voting on

Oregon's Ballot Measure 9 (2000)

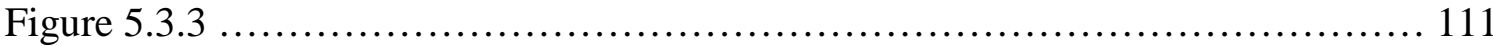

Tables

Relationship between county-level Democratic Party affiliations and voting on Oregon's Ballot Measure 42 (2006) 


\section{- Chapter 1 - \\ Introduction}

Why do some ballot initiatives pass and others fail on Election Day? What causal factors determine initiative contest outcomes?

\section{Introduction to the topic: Policymaking without their permission?}

Elected representation is the primary vehicle for American democracy throughout all 50 statehouses and Washington D.C. Federal and state legislators and executives are popularly elected at regular intervals. Judges too are either elected, subject to recall, or appointed by one democratically elected agent with the approval of some other democratically elected body. Representative democracy, as Framer's like John Madison envisaged it, was meant to incorporate deliberative, stabilizing, and power-sharing elements of statecraft. These would serve to prevent overly energetic majorities from doing anything too upsetting to the minorities' preferences.

Emerging with Progressive and Populist movements of the early $20^{\text {th }}$ century, 24 of the United States now have an arena for citizen lawmaking called the ballot initiative process, a political institution where citizens can circulate petitions to place state laws and constitutional amendments on the ballot for a Yes or No vote. The citizens' initiative is, at least on the surface level, a very different institutional actor in the process by which policy is made. Scholars to this day interrogate whether the ballot initiative process has any truly unique properties as an institution of democratic policymaking. ${ }^{1}$ How does the

\footnotetext{
${ }^{1}$ David McCuan and Steve Stambough, Initiative-Centered Politics: The New Politics of Direct Democracy, (Durham: Carolina Academic Press, 2005) p. 4.
} 
ballot initiative process affect the ways by which individuals and groups demand policy that accords with their interests and values? How does the initiative contest option alter the manner that policy-demanders calculate through which channel they can best control policy?

Though not a democratic panacea, theoretically a ballot initiative process can correct out distortions in the process by which popular opinion is translated into public policy in 24 states. The process of allowing average citizens to initiate an up or down vote on a piece of legislation has the potential to allow for policy changes which overcome the carefully cultivated influence of moneyed interest groups on state government, the insidious effects of careerism, and many more of the systemic reasons why elected representation falls short of meeting the policy-demands of the public. ${ }^{2}$ In short, the ballot initiative process appears to breach a critical membrane of the power wielded by elected officials, the monopoly on making changes to official policy or the legislative agenda. Does the initiative really wipe clean the insidious influence of moneyed interests and party bosses? Does the process really give outsiders an effective means to change policy without the permission of the big donors or the two parties?

A satisfying inquiry into the ballot initiative process must illuminate the substantive differences or pointed similarities between ballot initiatives and other modes of democratic lawmaking. The central question becomes, what are the mechanisms that determine the outcomes of ballot initiative contests? Is this process different than that which governs electoral politics? Then, at this point, normative questions emerge related

\footnotetext{
${ }^{2}$ Ibid, p. 5-7.
} 
to how desirable one finds different determinants of success between ballot initiative contests and electoral politics.

These questions are important first because the policy stakes of initiative contests are high, and second because of the sheer size of initiative spending. In recent decades, ballot initiative contests have become one of the biggest destinations for political dollars. Unlike in candidate races, there are no limitations on contributions to ballot measure campaigns. What follows are a few facts to demonstrate the magnitude of ballot initiative campaign expenditures. In the 2012 general election in California, the amount of money spent to affect initiative contests was four times that spent to affect races for seats in the state legislature. ${ }^{3}$ Furthermore, the combined total of 2013 and 2012 initiative contest spending has been projected as a record-breaking $\$ 1.3$ billion in committee expenditures. $^{4}$

Explaining initiative contest outcomes has implications for policy and politics at the local, state, and federal level. Initiative contests outcomes not only alter the details of policy, they reorganize the processes by which policy is produced through changes to elections, constitutional provisions, and other elements of a state's institutional arrangements.

\section{Analytic frame}

\footnotetext{
${ }^{3}$ National Institute on Money in State Politics, "State Overview: California 2012," Follow The Money database, Accessed online.

${ }^{4}$ Reid Wilson, "Initiative spending booms past \$1B as corporations sponsor their own proposals," GovBeat, Washington Post (November $8^{\text {th }}, 2013$ ). Accessed online.
} 
What determines the outcomes of ballot initiative contests? This research paper examines the initiative process from the perspective of policy-demanding individuals and groups. Policy-demanders have a variety of channels to try and influence policy. Why do they sometimes pursue their preferred policies through the initiative process? Why do their efforts sometimes end in passage and sometimes end in defeat?

This paper will take up three different approaches to explaining how policydemanding individuals and groups achieve policy goals through the ballot initiative process.

- Approach \#1 examines explanations of passage that hinge on the effectiveness of campaign spending.

- Approach \#2 examines explanations of passage that focus on the relative broad diffusion or narrow concentration of the costs and benefits associated with a given initiative contest. This approach is heavily informed by the logic of collective action. $^{5}$

- Approach \#3 follows institutionally-embedded explanations of passage. These explanations place policy-demanding actors into the larger institutional context of ballot box policymaking within a whole constellation of other institutional actors.

Below, Table 1 compares three approaches to explanation in terms of their causal-

mechanistic structure. These three approaches will structure the experimental design and review of the literature that make up this paper.

\footnotetext{
${ }^{5}$ This line of reasoning was influentially articulated early on by Mancur Olson, The Logic of Collective Action (Cambridge: Harvard University Press,1965).
} 


\begin{tabular}{|l|l|l|l|}
\cline { 2 - 4 } \multicolumn{1}{l|}{} & Agent & Process & Outcome \\
\hline $\begin{array}{l}\text { Approach } \\
\# 1\end{array}$ & $\begin{array}{l}\text { Policy-demanding individuals } \\
\text { and groups }\end{array}$ & $\begin{array}{l}\text { Policy-demanders use their } \\
\text { financial resources } \\
\text { to change voter behavior }\end{array}$ & Passage/Defeat \\
\hline $\begin{array}{l}\text { Approach } \\
\# 2\end{array}$ & $\begin{array}{l}\text { Policy-demanding individuals } \\
\text { and groups }\end{array}$ & $\begin{array}{l}\text { Policy-demander exploits the } \\
\text { narrowness or breadth } \\
\text { of their preferred policy }\end{array}$ & Passage/Defeat \\
\hline $\begin{array}{l}\text { Approach } \\
\# 3\end{array}$ & $\begin{array}{l}\text { Policy-demanding individuals } \\
\text { and groups }\end{array}$ & $\begin{array}{l}\text { Policy-demander exploits } \\
\text { some feature of the } \\
\text { institutional environment }\end{array}$ & Passage/Defeat \\
\hline
\end{tabular}

TABLE 1: Three approaches to explaining initiative contest outcomes

\section{Contribution to the literature:}

This thesis paper contributes to the literature on initiative contests first by synthesizing the various strands of literature that seek to explain passage. The review of the literature suggests new avenues for exploring the role of money in contest outcomes. This paper makes an argument for the importance of understanding the individual decision-making of the policy entrepreneurs who navigate the initiative arena. Yet, these explanations only make sense when placed inside the larger institutional context. This paper identifies institutionally-embedded explanations of initiative contest outcomes as an area of potential growth in ballot initiative scholarship. Finally, this paper provides guidance for enriching explanations of ballot initiative politics by expanding the outcome-of-interest beyond passage/failure to potential political and procedural objectives. 
This paper's three experimental sections each provide a different contribution to the current body of knowledge related to the ballot initiative process. First, this author provides evidence of strategic financing of initiatives based on the early competitive dynamic. This behavior biases estimates of spending's effectiveness if excluded from an explanatory model. Evidence is also provided of Yes-demanding groups achieving extraordinarily high passage rates without spending much money or facing much competition in cases where their initiative takes an early and decisive lead. This phenomenon also merits incorporation into the econometric models by which the influence of money is measured.

This thesis also provides evidence that the initiative process is largely an arena of majoritarian politics - conflicts in which both broad costs and broad benefits are at stake. In these predominant, majoritarian-type political situations, the passage rate is by far the highest. The research contained here adds to a body of findings which suggest that the initiative process is a site of regular victories for broad groups with limited financial resources. In line with earlier authors, this author observes a correlation which supports the premise that policy-demanders with broadly diffused interests exercise a competitive advantage in the initiative arena. ${ }^{6}$

The final section of this project provides an analysis of the initiative within the context of the larger institutional environment. Specifically, does the ballot initiative process operate independently of party politics? How much does the structure of partisan attachments structure the coalitions from which winning initiative efforts are built?

\footnotetext{
${ }^{6}$ E Elisabeth Gerber, The Populist Paradox: Interest Group Influence and the Promise of Direct Legislation (Princeton: Princeton University Press, 1999) p. 65.
} 
Evidence is provided of a reliable and often quite high correlation between a county's party attachment and its voting in particular initiative contests. This suggests that ballot initiative politics takes place within the coalition-building rules of electoral politics. Therefore, ballot initiative passage and defeat is partly determined by the policydemanders ability to exploit the current configuration of partisan attachments. Evidence is provided that ballot initiative policymaking does not take place outside party politics, as has elsewhere been suggested.

The final section of this paper provides recommendations for future researchers investigating the mechanics of success in the ballot initiative process.

\section{Philosophy of social science}

Explanations, by their definition, invoke causal stories. According to philosophy of social science scholar Daniel Little in his 1991 book Varieties of Social Explanation, explanatory reasoning invokes three central ideas: "[1)] the ideas of a causal mechanism connecting cause and effect, [2)] the idea of a correlation between two or more variables, and [3)] the idea that one event is a necessary or sufficient condition for another." ${ }^{, 7}$ Little is certain to note that, particularly in light of unique properties of the social world, a model of social explanation must embrace probabilistic causal claims wherein a condition might not be fully necessary or sufficient to bring about an effect, but it does significantly change the probability of the phenomenon's occurrence. ${ }^{8}$

\footnotetext{
${ }^{7}$ Daniel Little, Varieties of Social Explanation, (Boulder: Westview Press, 1991) p. 4.

${ }^{8}$ Ibid.
} 
Explanation is one of the two main forms of argumentation (along with description) that has been the territory of scientists and philosophers since ancient times. Explanation is at the core of all scientific inquiry - from microbiology and astrophysics through anthropology and political science. It is important to conduct this research with a thought-out and engaged philosophy of how to evaluate social scientific explanations. This author takes a methodological individualist stance, meaning simply that all explanations of social phenomena must come packaged with at least some gesture towards an explanatory sketch of a causal mechanism involving the goal-directed behavior of individual human beings. The methodologically individualistic approach this researcher claims is akin to that articulated by Daniel Little, who argues that the primary idea underneath all explanatory reasoning is "a causal mechanism connecting cause and effect." 9

So "mechanisms" are essential to explanation. Explanations must be compatible with our understandings of the behavior of intentional individuals. What is meant exactly by this term mechanism? Sociologist Arthur Stinchombe defined mechanisms as "bits of theory about entities at a different level (e.g. individuals) than the main entities being theorized about (e.g. groups), which serve to make the higher level theory more supple, more accurate, or more general." ${ }^{10}$ Figure 6 displays the skeleton for the explanations the reader will encounter in this Literature Review and subsequent experimental design.

\footnotetext{
${ }^{9}$ Ibid, p. 14.

${ }^{10}$ Arthur L. Stinchombe, "The Conditions of Fruitfulness of Theorizing About Mechanisms in Social Science," Philosophy of Social Sciences, Vol. 21, No. 3, (Sept. 1991) p.367.
} 

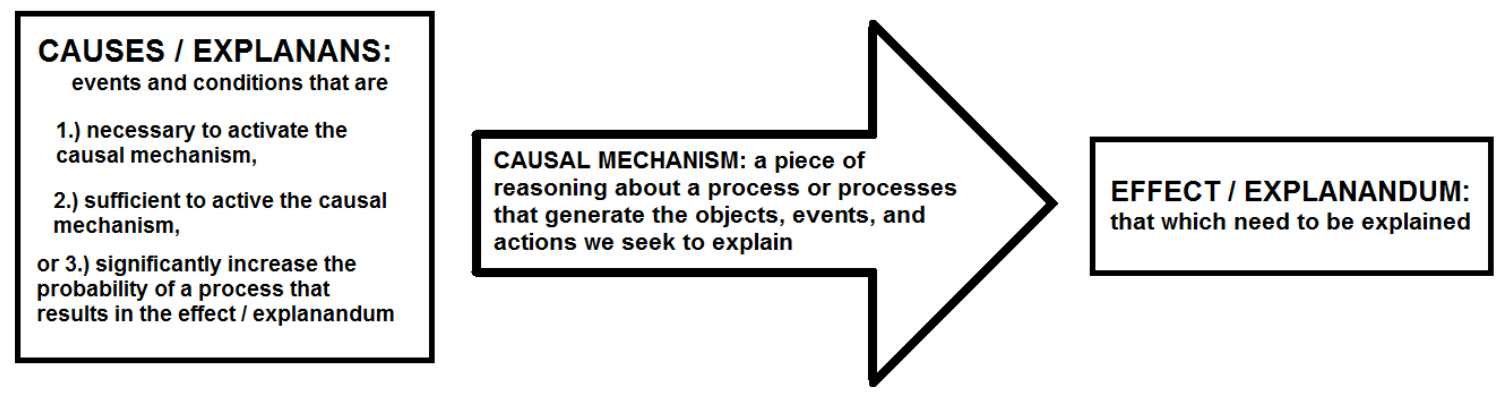

\section{FIGURE 1.1: Generic causal-mechanistic story}

The use of these repeated explanatory schematics responds to Daniel Little's challenge to social scientists published online in June of 2011: "If we assert a causal or explanatory relation between one social entity or condition and another, we must be prepared to offer a credible sketch of the ways in which this influence is conveyed through the mentalities and actions of individuals."11

Figure 1.2, seen below, shows a more specific skeleton for the explanations of passage that will be covered in this Literature Review's subsections for Approaches \#1-3. Recall that we need to be explaining the mechanisms through which goal-directed actors in the initiative process achieve passage through the actions of goal-directed voters with their own sets of preferences, intentions, commitments, and beliefs.

\footnotetext{
${ }^{11}$ Daniel Little, "Microfoundationalism," Understanding Society, accessed online on September $2^{\text {nd }}, 2013$ (Published June 28, 2011).
} 
POLICY-DEMANDING INDIVIDUALS AND GROUPS:

Approach \#1: differences in resources of Yes and No efforts

Approach \#2: cost-benefit distribution activated by a given initiative

Approach \#3: meeting the demand for assembling a winning coalition

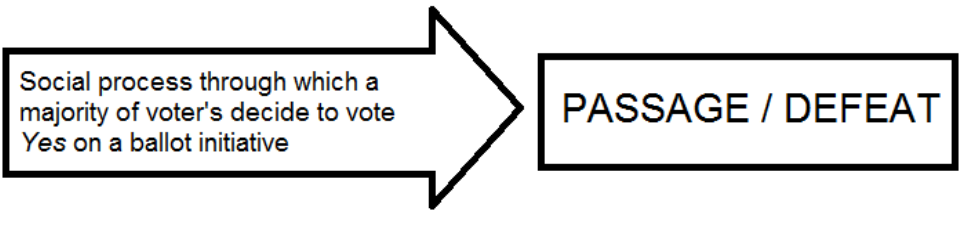

FIGURE 1.2: Structure for this paper's explanations of initiative contest outcomes

The causes we examine will relate to the intentional behavior of policydemanding individuals and groups pursuing their objectives through the initiative process. The effect is represented inside the box on the right, the one at which the arrow is pointed. Passage is the main dependent variable.

\section{Terminology}

The effect is always to be defined in terms of passage or defeat, or relatedly, in terms of vote share. Consequently, discussions of the "effectiveness" of different causal variables will be referring to whether that variable has the property of influencing an initiatives probability of passage. Furthermore, any time ballot initiative "contest outcomes" are mentioned, the outcome in question is always either passage/defeat or vote share. Accordingly, unless otherwise stated, ballot initiative "success" shall refer to ballot initiative passage.

For analytical clarity, this thesis will use the terms Yes and No spending to consolidate the various terminology employed in different studies to describe spending directed at promoting the respective passage or defeat of an initiative. Yes spending is 
conducted by Yes campaigns for the purpose of prompting voters to accept ballot initiatives. No spending is conducted by No campaigns in order to persuade voters to reject the initiative in question. 


\section{- Chapter 2 -}

\section{Literature Review}

What causes initiatives to pass? This literature review is structured around three approaches to explaining initiative contest outcomes. The first approach (\#1) investigates the influence of campaign money in affecting initiative contest outcomes. Explanations here will focus on the financial resources of Yes and No campaigns as potential factors affecting passage. Approach \#2 looks to the breadth or concentration of a proposed initiative's costs and benefits to explain the mechanisms governing passage and rejection. Finally under Approach \#3, this review covers institutionally-embedded explanations of initiative contest outcomes. These explanations place initiative politics into the context of the broader environment of multiple competing institutions of democratic policymaking. Additionally, Approach \#3 will end with research into proposed objectives of initiative process actors which might operate on their behavior independently from passage objectives. That is to say, possible ballot initiative contest motivations which go beyond passage/defeat.

\section{Explanatory Approach \#1: Money matters}

What does the social science literature offer in terms of understanding the ability of policy-demanding actors to buy policy, in general? Where can we find those mechanisms whereby the financial expenditures of certain policy-demanding actors and groups influences the policy output of government at any level? 
This section begins by reviewing the older literature on the relationship between campaign expenditures and initiative contest outcomes. Then, the next subsection details the research conducted on the influence of moneyed policy-demanders in the legislatures, and how methodological breakthroughs in that field have been incorporated into thinking about ballot initiative contest outcomes.

Much has been written over the years debating the effect of campaign dollars in increasing or decreasing the likelihood voters will approve or reject a given statewide ballot initiative. This initial section of the Literature Review analyzes research which uses the passage (or vote share) of an initiative as the dependent variable, and the amount of money spent in support or opposition to an initiative will be the independent variables. In short: can money provided by policy-demanding individuals and groups be used to buy or prevent passage of an initiative? How and in what way does money spent in initiative campaigns influence outcomes? Is there an asymmetrical effect, wherein money is more effective in opposition to an initiative than it is in favor of it?

In the broadest possible terms, the scientific literature has shifted from an older literature downplaying the role of No campaign spending and almost total rejection of the efficacy of Yes campaign spending, ${ }^{12}$ towards a newer literature that challenges the research designs of past authors and argues that both Yes and No spending have significant and relatively symmetric effect. ${ }^{13}$ Along the way, breakthroughs in research on candidate elections were brought into the initiative literature with path-breaking

\footnotetext{
${ }^{12}$ Arthur Lupia and John Matsusaka, "Direct Democracy: New Approaches to Old Questions, Annual Review of Political Science, Vol. 7, (2004) pgs. 463-482.

${ }^{13}$ Thomas Stratmann, "The Effectiveness of Money in Ballot Measure Campaigns," Southern California Law Review, Vol. 78 (2005); John de Figueiredo, Chang Ho Ji, and Thad Kousser, "Financing Direct Democracy: Revisiting the Research on Campaign Spending and Citizen Initiatives," The Journal of Law, Economics, \& Organization, Vol. 37, No. 3 (2011).
} 
consequences on findings. This forthcoming section will deal with this debate, and all of the explanatory models that get presented along the way.

\section{Early research finds limited effects and asymmetry}

The earlier literature on the capacity of money to buy initiative contest outcomes suggests a limited and asymmetrical impact from campaign expenditures. Sometimes campaign spending was said to not matter much at all in determining election outcomes. ${ }^{14}$ Other studies suggested that the only money that significantly impacted outcomes was spent by opposition groups seeking No votes. ${ }^{15}$ In sum, scholars agreed money was pretty ineffective at changing initiative contest outcomes. To the extent that it was influential, its influence reinforced the status quo, but could not purchase alteration of the current order through buying Yes votes.

Researchers John Owens and Larry Wade were among the early and longdominant voices in the academic literature who downplayed the ability of money from any group, on any side of an initiative contest, to affect outcomes. In a 1986 study, they

\footnotetext{
${ }^{14}$ John R. Owens and Larry L. Wade, "Campaign Spending on California Ballot Propositions, 1924-1984: Trends and Voting Effects," The Western Political Quarterly, Vol. 39, No. 4, (1986) pgs. 675-689.

${ }^{15}$ Steven Lydenberg, Bankrolling Ballots: The Role of Business in Financing State Ballot Question Campaigns, Council on Economic Priorities (1979); Ronald J. Allen, "The National Initiative Proposal: A Preliminary Analysis," Nebraska Law Review, Vol. 58, (1979) pgs. 1034-1036; Randy M. Mastro, Deborah C. Costlow, and Heidi P. Sanchez, "Taking the Initiative: Corporate Control of the Referendum Process through Media Spending and What to Do about it," Federal Communications Law Journal, Vol. 32, (1980) pgs. 315-269; David Lowenstein, "Campaign Spending and Ballot Propositions: Recent Experience, Public Choice Theory, and the First Amendment," UCLA Law Review, Vol. 86 (1982); David Magelby, Direct Legislation: Voting on Ballot Propositions in the United States. (Baltimore: John Hopkins University Press, 1984); John S. Shockley, "Direct Democracy, The Initiative Process in Colorado Politics: An Assessment, Boulder Bureau of Governmental Research and Services, University of Colorado (1980); John S. Shockley "Direct Democracy, Campaign Finance, and the Courts," University of Miami Law Review, Vol. 39, (1985) pgs. 377-428; David D. Schmidt, Citizen Lawmakers: The Ballot Initiative Revolution, Philadelphia: Temple University Press (1989); David Magelby, "Direct Elections in the United States," in Referendums Around the World, eds. David Butler and Austin Ranney. Washington, DC: The AEI Press (1994); Chang Ho Ji "California's Direct Democracy 1976-1998: Predictors, Outcome, and Issues" (paper presented at the Annual Meeting of the Western Political Science Association, Seattle, 1998); Lupia and Matsusaka, "Direct Democracy: New Approaches to Old Questions."
} 
examined campaign spending and election outcomes in the sixty years from 1924 until 1984, and found no significant association or substantive relationship between the two. Using four statistical models that examined not just passage but also vote share, Owens and Wade concluded that "there is at best only a modest connection" between a campaign's finances and its odds of success - a judgment highly skeptical of any role for money in buying initiative contest outcomes. ${ }^{16}$

Late $20^{\text {th }}$ century academic explanations of the relationship between passage and campaign spending are easily characterized by a consensus on muted and asymmetric effects, ${ }^{17}$ but some disagreed with these conclusions, and few agreed entirely on the causation underlying them or the normative implications. With so much money spent in aggregate on both sides of initiative contests, Owens and Wade conclusions seemed counterintuitive at best. Why would campaigns attract and spend money in such large numbers if their expenditures did not increase a given initiative's odds of passing?

Dissenters like Betty Zisk contended that money matters regardless of which side spends it. ${ }^{18}$ In 1987 , Zisk performed a multi-state study of 50 ballot initiative campaigns occurring between 1976 and 1982 in four diverse states: California, Massachusetts, Michigan, and Oregon. In her sample, the highest spending side prevailed on Election Day in 80 percent of the cases, regardless of the amount spent by the other side, the source of the money, or the issue type. Zisk's findings suggested that public opinion on a ballot question could change drastically when one side heavily outspent the other, looking at 32 campaigns with available polling data and finding that 53 percent of the

\footnotetext{
${ }^{16}$ Owens and Wade, "Campaign Spending on California Ballot Propositions," pgs. 33-35.

${ }^{17}$ Lupia and Matsusaka, "Direct Democracy: New Approaches to Old Questions."

${ }^{18}$ Betty Zisk, Money, Media, and the Grass Roots. (Newbury Park: Sage, 1987).
} 
time, voters' initial preferences would shift towards whichever side spent the most money.

Other contemporary scholars saw campaign money as capable of determining election outcomes, but always with an asymmetrical effect in which if money spent in pursuit of Yes votes had any influence, it was significantly less relative to the purchasing power of money spent on No votes. Daniel Lowenstein made one of the earliest and most influential cases for this asymmetrical effect favoring money spent by an initiative's opponents over that spent by its proponents. ${ }^{19}$ Lowenstein found that when the opponents outspent the proponents by at least $2: 1$, the opponents won 90 percent of the time. Conversely, if the proponents outspent the opponents by at least $2: 1$, the proponents only won $64 \%$ of the time. This asymmetrical effect became a central part of the research and debate over the role of money in determining initiative contest outcomes.

Lowenstein's contemporary, David Magelby, confirmed the existence of an asymmetrical effect favoring money spent in No campaigns over that spent in yes campaigns. Following Lowenstein's approach closely, Magelby separates the measures into three categories based on whether the opponents, the proponents, or no one had a 2:1 spending advantage. Magelby found that proponents with advantages won in less than half the cases. While at an 87 percent success rate, opponents with a 2:1 spending advantage could "virtually guarantee the defeat of an initiative." 20 That study was published in 1984. Ten years later in 1994, Magelby would again find evidence of the asymmetrical effect. Looking at the initiatives in the years since his last study, Magelby

\footnotetext{
${ }^{19}$ Lowenstein, "Campaign Spending and Ballot Propositions."

${ }^{20}$ Magelby, Direct Legislation, pgs. 146-148.
} 
found that ballot measures had failed in ten of the top eleven cases where the Yes

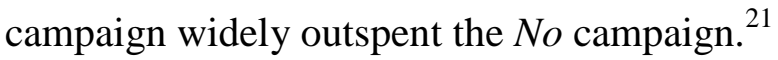

Magelby postulated from his results that upon hearing information provided predominantly from the Yes side, voters became skeptical and tended to reject the propositions. Future scholars would build on this idea of a risk-averse voter. ${ }^{22}$ But for the time being, the main takeaway from Magelby's work was to reinforce the asymmetrical effect theory associated with Lowenstein. The notion of asymmetrical effects in initiative campaign spending would crystalize into a conventional wisdom that has only recently been directly and forcefully challenged. ${ }^{23}$

Among this older body of literature, many of the older studies used simpler, bivariate modeling. ${ }^{24}$ More recent studies employed more complicated multivariate modeling to predict the fate of initiative by the levels of Yes and No spending. ${ }^{25}$ Overall though, the old literature is best characterized by two feature. First, the old literature provides evidence of muted and No-favoring asymmetric effectiveness of spending upon outcomes with near uniform consistency. Second, and more critically, the old literature

\footnotetext{
${ }^{21}$ Magelby, Direct Elections in the United States.

${ }^{22}$ Shaun Bowler and Todd Donovan, Demanding Choices: Opinion, Voting, and Direct Democracy, (Ann Arbor: University of Michigan Press, 1998).

23 Thomas Stratmann, "The Effectiveness of Money in Ballot Measure Campaigns"; de Figueiredo et al. "Financing Direct Democracy."

${ }^{24}$ Eugene C. Lee, "California," in Referendums: A Comparative Study of Practice and Theory, eds. David Butler and Austin Ranney (Washington DC: AEI, 1978); Allen, "The National Initiative Proposal"; Lydenberg, Bankrolling Ballots; Lowenstein, "Campaign Spending and Ballot Propositions"; Owens and Wade, "Campaign Spending on California Ballot Propositions".

${ }^{25}$ Susan Banducci, "Direct Legislation: When Is It Used and When Does it Pass?" in Citizens as Legislators, eds. Shaun Bowler, Todd Donovan, and Carline J. Tolbert (Columbus: Ohio State University Press, 1998) pgs. 109-131; Elisabeth Gerber, The Populist Paradox; Elizabeth Garrett and Elisabeth Gerber, "Money in the Initiative and Referendum Process: Evidence of its effects and prospects for reform," in The Battle Over Citizen Lawmaking, ed. M. Dane Waters (Durham, NC: Carolina Academic Press, 2001); Donovan and Bowler, Demanding Choices.
} 
doesn't take into account either the endogeneity of variables or the likelihood that spending is marginally less effective at higher levels.

The next subsection will examine how the literature on candidate elections experienced some of the same problems as initiative literature, and how methodological solutions introduced in the electoral context migrated into the arena of ballot initiative politics.

\section{Candidate contest outcomes and campaign spending:}

When it comes to money in politics, the bulk of academic research focuses on candidate elections. This body of empirical literature is dominated by work which examines the relationship between campaign spending levels and the identity of winning candidates. In a 2005 literature review, Thomas Stratmann wrote, "While incumbents and challengers spend much time on fund-raising and appear to believe that money is an important ingredient in winning elections, academic researchers for the most part have trouble establishing a causal and quantitatively important connection between spending and vote shares. ${ }^{26}$ The apparent ineffectiveness of incumbent campaign spending is one of the central puzzles of campaign finance literature. An already thorny causality question about campaign spending and candidate contest outcomes is made especially difficult in the case of incumbent spending.

Why do researchers struggle to demonstrate that spending, especially incumbent spending, produces causes changes in the identity of election winners? The problem is

\footnotetext{
${ }^{26}$ Thomas Stratmann, "Some talk: Money in politics. A (partial) review of the literature," Public Choice, Vol. 124, (2005) p. 3.
} 
largely one of endogeneity between the causal variable (spending) and the effect variable (contest outcomes). The causal logic of an experiment assumes that one's independent and outcome variables are exogenous to each other. In a classic experimental context, this is accomplished using random assignment procedures.

However, in the quasi-experimental context researchers are left with groups which only exist out in the field. In the context of candidate races the argument is that spending, especially incumbent spending, is strategically made available to candidates by policy-demanders. Policy-demanders seek to win influence with the eventual winner of the election. For this reason, there is a tendency to try and pick winners. This strategy changes how the data must be interpreted, because there is something pointedly not random about the patterns through which campaign spending is being (assigned) made available to candidates.

There is a tendency for policy-demanders to try and pick winners, bandwagoning behind strong candidates who appear likely to win. Figure 2.2.1 depicts the endogeneity at play in this example. 


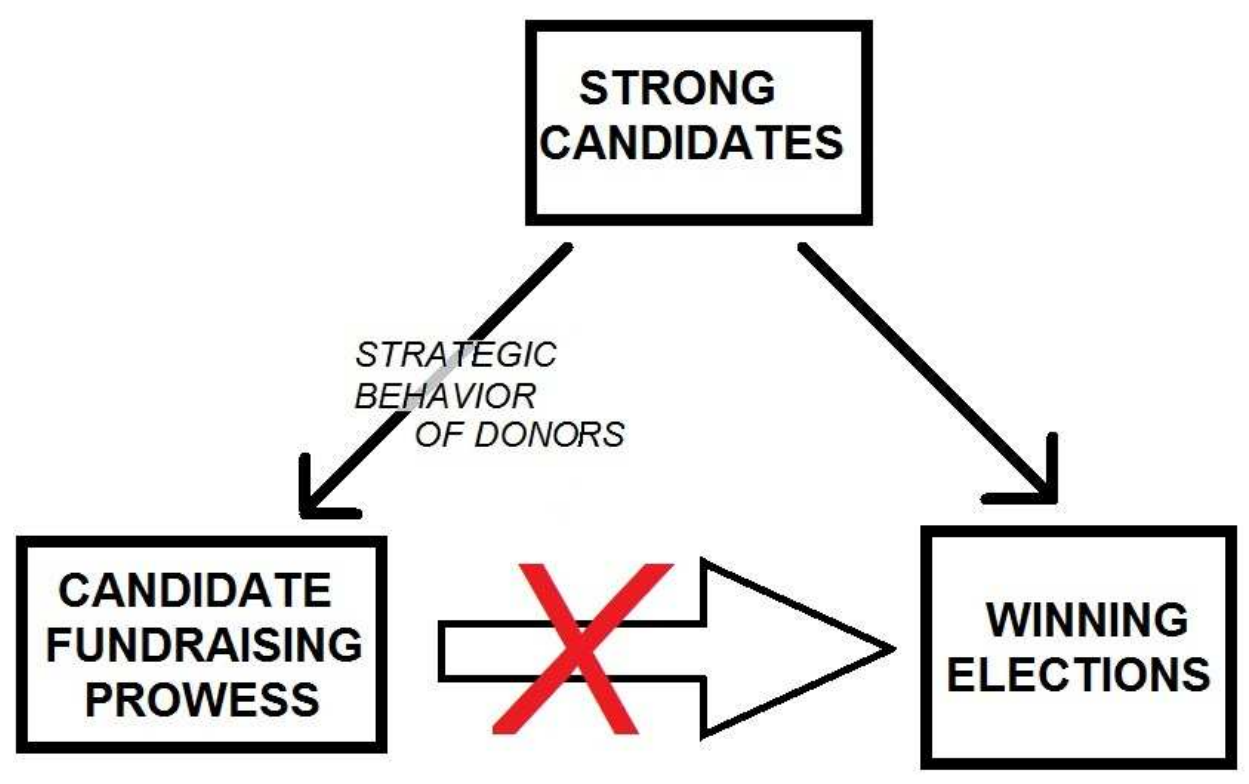

FIGURE: 2.1.1: Endogeneity of candidate campaign spending to identity of Election Day winner

The strength of an incumbent's challenger is likely to stimulate contributions for the incumbent. Likewise the tendency will be for higher funding to be directed towards challengers facing an uphill slough against strong incumbents. As Thomas Stratmann put it in a 2005 literature review on money in politics, "incumbents' vote shares and spending are simultaneously determined. ${ }^{27}$ Incumbents in competitive races may spend more to win reelection and lose than incumbents facing no serious challenge to win. This could lead to the erroneous conclusion that more campaign spending leads to smaller vote shares, or it could just bias estimates of the effectiveness of voting downwards towards zero. Either way, failing to control for the unobserved variables of incumbent and challenger quality leads to critical estimation errors.

\footnotetext{
${ }^{27}$ Stratmann, "Some talk," p. 138.
} 


\section{The new literature on the effectiveness of spending:}

Publishing in 1998, Susan Banducci would find asymmetry too. ${ }^{28}$ The previous scholars said that No spending was very effective, whereas Yes spending had no significant effect. Banducci found significant effects for Yes spending, but also the same asymmetrical effect favoring No spending. Money spent by initiative proponents has an effect on securing desired outcomes, Banducci claimed, it just is not as powerful as the effect of money spent by initiative opponents. There are smaller but still significant effects present for Yes spending. Banducci's novel findings were in part owed to her novel research design. Her study acts as prelude to a new consensus around more substantive effects for both Yes and No spending. In common with Banducci’s design, the new literature is marked by efforts to anticipate and factor out the endogeneity between the variables involved.

Banducci's 1998 study aimed to develop a multivariate regression model with instrumental variables and multiple layers of controls that would explain initiative contest occurrences and outcomes. She first explained why certain initiatives qualified for the ballot, then why passage occurred when it did. Her novel methodological design would incorporate two new concepts that have critically shaped how subsequent studies approached these questions. First Banducci confronted the endogeneity of spending variables to contest outcome variables. Second, Banducci recognized the diminishing marginal returns to which campaign spending is subject.

Banducci's study examined all direct legislation contests which occurred in 2 states - California and Oregon - between 1976 and 1990. Drawing upon the insight of

\footnotetext{
${ }^{28}$ Susan Banducci, "Direct Legislation: When Is It Used and When Does it Pass?"
} 
Jacobson (1980), Banducci argued that "because [the level of Yes spending] is a response to the appearance of a strong challenge... [Yes spending] is not a variable that is completely external to any model that predicts initiative voting." ${ }^{29}$ Via Banducci, Yes and No spending levels are "wrapped up in each other," or to use to jargon of statistics, they are multicolinear variables. ${ }^{30}$

So, given the endogeneity of spending, Banducci argued for the power of applying a "two-stage model and some indicator of the controversy or competitiveness of each proposition to correctly specify how spending affects outcomes." ${ }^{31}$ The first stages of Banducci's passage model predicted an initiative's Yes spending. She constructed indicators that reflect how competitive or controversial each ballot initiative was. Among these indicators, Banducci included a measure of whether or not a proposition contained provisions regulating or taxing an industry. Banducci's indicators of controversiality and competitiveness are regressed on Yes spending to predict how much Yes spending is fueled by the threat of opposition.

In the second stage of Banducci's model, Yes spending predicted in the first stage is used, along with No spending, to predict contest outcomes. Through this two-stage model, Banducci aimed to isolate and eliminate the effects on Yes spending that are driven by the anticipated closeness or competitiveness of contests. This approach, informed by innovations in research on electoral politics, would come to define the new approach to estimating money's effectiveness in determining contest outcomes.

\footnotetext{
${ }^{29}$ Gary Jacobson, Money in Congressional Elections (Cumberland: Yale University Press, 1980); Banducci, p. 124-125.

${ }^{30}$ Banducci, p. 127.

${ }^{31}$ Ibid, p. 125.
} 
Beyond tackling endogeneity, Banducci's research design was also novel for its incorporation of her awareness of the diminishing marginal returns to which campaign spending is subject. Via Banducci, it is likely that the marginal returns on Yes and No spending are reduced at very high levels of spending. To factor this dynamic in, Banducci uses the natural log of Yes and No expenditures in order to help model the potential nonlinear effects of spending on outcomes.

In regards to the first stage of her model, Banducci's 1998 study posited a "significant relationship between [Yes and No] spending, suggesting that [Yes] spending is a function of $[\mathrm{No}]$ spending., ${ }^{, 32}$ Banducci claimed that her equations deployed in the first stage "explain over $40 \%$ of the variation in [Yes] spending on all of these propositions." 33 In terms of the second stage estimates, Banducci found that "once [Yes] spending has been purged of effects shared with $[\mathrm{No}]$ spending, [Yes] spending does have a significant inverse effect on the proportion of people voting 'no' on ballot measures in both states." 34

Consistent with past authors, Banducci found an assymetric effect where, dollar for dollar, No spending had "a much greater impact on votes" than Yes spending. ${ }^{35}$ However, where past studies had found that Yes spending was generally ineffective, Banducci found that Yes spending was indeed a significant factor in contest outcomes, even if relative to No spending its effect appeared more limited. Banducci's innovation was the incorporation of methodological tools which accounted for the endogeneity of

\footnotetext{
${ }^{32}$ Ibid, p. 126.

${ }^{33}$ Ibid, pgs. 126-127

${ }^{34}$ Ibid, 127.

${ }^{35}$ Ibid, 129.
} 
campaign spending and the nonlinear nature of its effects upon vote share. Banducci's work opened the door for a new line of studies which, in turn, have overturned the old consensus on muted and asymmetric effects for campaign expenditures in shaping initiative contest outcomes.

The most recent research on the effectiveness of money in ballot initiative contests challenges the conceptualization of critically limited and asymmetrical effects for campaign spending. Thomas Stratmann's 2005 article on the effectiveness of ballot measure campaign money begins with the author placing himself within the context of a broader field of academic research on electoral campaigns. That literature, as Stratmann characterized it, had long been plagued by great difficulties in establishing the causal link between the magnitude of resources spent by policy-demanding actors and the respective passage or defeat of their preferred policy or, as the case may be, candidate. Stratmann's 2005 and 2006 research distances itself from a body of literature he considered to have confused "mere correlation" ${ }^{36}$ for explanation. By "disentangl[ing] the causal effects" of campaign spending upon passage, Stratmann reasoned that a novel research design could "find that interest group pressures can change political outcomes." ${ }^{37}$ In short, Stratmann identified a large problem (the endogeneity problem) that had long undercut most all explanations of initiative contest outcomes.

A causal argument necessitates a counter-factual. Something surely cannot be said to cause an event without an understanding of how and why the outcome could have unfolded differently. In experiments, the control group provides evidence of the

\footnotetext{
${ }^{36}$ Stratmann, "The Effectiveness of Money," p. 103.

${ }^{37}$ Ibid.
} 
counterfactual. But all too often in political science, counterfactuals can be extremely difficult to establish in quasi-experimental designs employing field data. The Stratmann research design grapples with the counterfactual dilemma though its decision to "establish a benchmark against which to evaluate the effectiveness of campaigning." Stratmann seeks this "benchmark" in the form of an indicator he constructs to gauge a given initiatives initial likelihood of passage. A measurement of underlying voter sentiment is used to estimate an initiative's initial likelihood of passage.

Stratmann argued that an explanation of money's causal power required a "technique that accounts for the fact that groups act strategically and that interest groups determine how much they spend based on underlying voter sentiment." 38 In other words, mere correlations underestimated the effectiveness of Yes spending by failing to appreciate the tendency for contributions to be systematically directed towards initiatives that began the campaign with dismal public support. Meanwhile "sure thing" campaigns recurrently begin with a high probability of passage and attract little spending. The strategic behavior or policy-demanding individuals and groups consistently organizes the field data in a way that would cause distorted estimates if not properly accounted for in the estimation procedures.

Stramann's data comes from 18 ballot measure contests that occurred in 36 counties within the state of California between 2000 and 2004. Stratmann substitutes television advertising spending for total campaign spending, and his main analytical unit is the county. An indicator was specifically constructed for each county to gauge underlying voter sentiment regarding each initiative. Additionally, an indicator was

\footnotetext{
${ }^{38}$ Stratmann, "The Effectiveness of Money," p. 108.
} 
constructed for each of the 36 ballot measures to capture the underlying voter sentiment at a statewide level. Stratmann then employs fixed-effect estimation on the data. His unit of observation is a measure of the vote share for each ballot measure within a particular county.

The findings from Stramann's study were significant and path-breaking. "These results," Stratmann wrote, "sharply contrast with the findings of previous studies." ${ }^{39}$ Yes spending was found to be at least as productive as $N o$ spending. There were even cases where Yes spending was found to be significantly more productive than No spending. This suggested that Yes spending had no predetermined disadvantage in the effort to affect voter behavior.

Breaking with the large majority of previous studies, Stratmann claimed evidence of statistically significant effects for both Yes and No spending. Furthermore, these effects were judged to be roughly symmetrical. Stratmann concluded that one could infer the potential for interest groups to offset one another's spending. An effective countercampaign can partially - or often completely - offset the influence of spending from other policy demanding individuals and groups.

Like Banducci and Stratmann before them, the next authors to tackle this topic would craft their research techniques to account for the endogeneity of campaign spending to ballot measure outcomes. A classic technique for dealing with endogeneity problems involves the use of instrumental variables. The previous section dealt with methodological breakthroughs in the congressional research context where instrumental variable techniques were utilized to address endogeneity problems. In doing so, this

\footnotetext{
${ }^{39}$ Ibid, p. 114.
} 
research transformed the academic understanding of the causal properties of interest group spending in electoral politics.

The 2011 article authored by John de Figueiredo, Chang Ho Ji, and Thad Kousser employed an instrumental variable design and found, like Stratmann, significant and roughly symmetrical effects. Like Stramann, de Figueriedo et al. prefaced their research designs by running their data through the sort of simpler correlational models which implicitly assumed the exogeneity of variables when used to make inferences about the effectiveness of campaign spending. The authors find that, indeed, using the old cruder methods of the old literature, the effects of the spending within their dataset does indeed appear to be muted and asymmetrical.

De Figueiredo et al. highlighted two recurrent patterns of strategic behavior seen in policy-demanding individuals and groups in regards to their likelihood of financing ballot initiative contest campaigns. In the first recurrent strategic situation, "narrow interests often spend large sums to pass measures with slim majorities." Whereas in the second situation, a measure with wide appeal is able to spend less and still achieve passage. Failing to take into account the strategic behavior of policy-demanding actors leads to one's research becoming invalidated by the sort of endogeneity problem depicted in Figure 2.1.2 


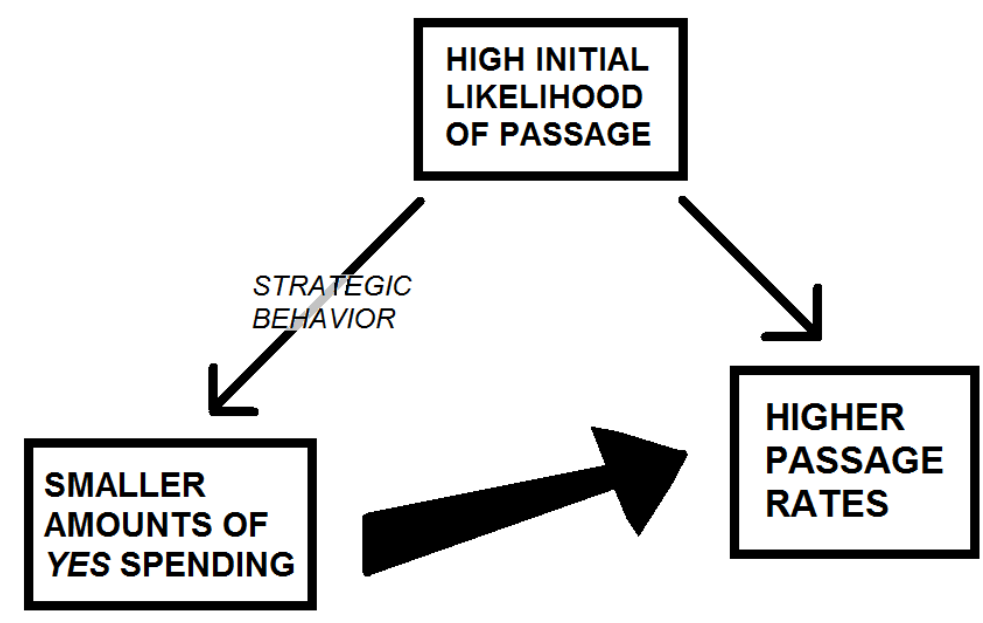

FIGURE 2.1.2: Endogeneity problem plaguing estimates of the effect of spending upon passage rates

De Figueiredo et al. argued that "the puzzling asymmetry" of past studies disappears when "more flexible econometric techniques" are deployed which account for "how the concentration of costs and benefits can determine financial support for a policy proposal. ${ }^{, 40}$ Their study analyzed all California ballot measures from 1976-2004. The dataset contained 328 contests in all. Through expanding the sample of ballot measure's used by Stratmann to include seven times as long of a time period, de Figueiredo et al. aimed to establish greater external validity than that previous study of the same state. De Figueiredo et al. examined overall spending as opposed to isolating television advertising like Stratmann. Multiple instrumental variables are used, which vary across each of the 329 observations. Their major instruments are measures reflecting the level of concentration of costs and benefits to the public represented for a given ballot initiative.

\footnotetext{
${ }^{40}$ de Fig et al., "Financing Direct Democracy," p. 3.
} 
This typology of distributions of costs and benefits was adapted from past authors $^{41}$ and will be critical to the research design of this thesis's Methods chapter.

Figures 2.1.3 and 2.1.4 depict the relationship which de Figueiredo et al. portray between the concentration of costs and benefits, Yes and No spending levels, and the vote share of ballot initiatives.

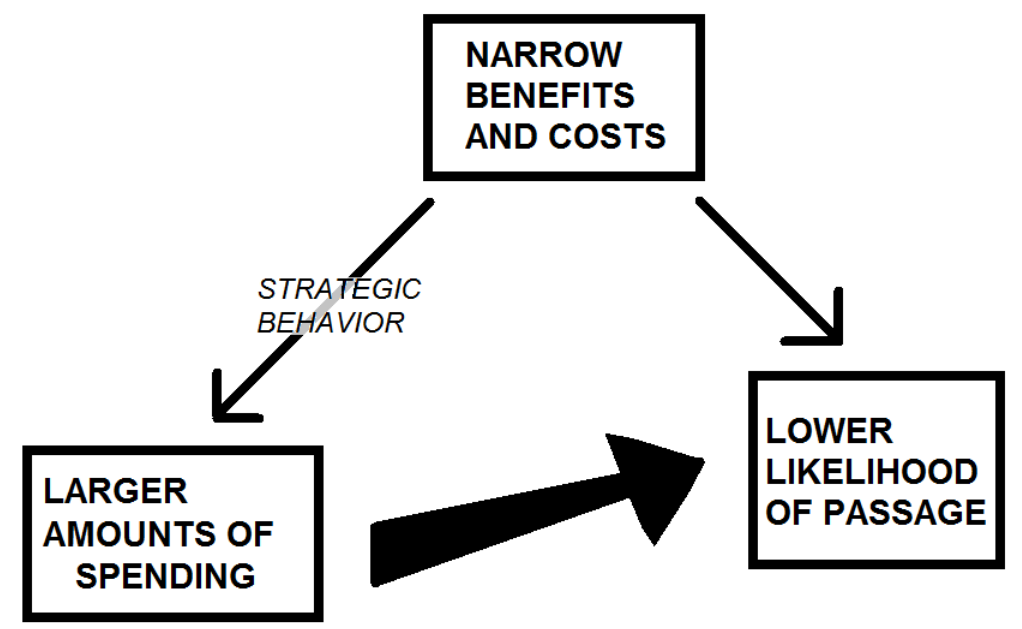

FIGURE 2.1.3: Recurrent strategic situation where narrow groups spend large on initiatives with slim chances of passing

In the first strategic situation seen in Figure 2.1.3, contributions flood to the initiative advocacy of narrow-benefitting initiatives which begin with slim majorities at best indicating intention to vote Yes. Failing to anticipate the codetermination at play here leads to underestimating the effect of spending, especially Yes spending from narrow groups. In the second strategic situation seen in Figure 2.1.4, broad groups pass initiatives

\footnotetext{
${ }^{41}$ Anne Campbell, "The Citizen's Initiative and Entrepreneurial Politics: Direct Democracy in Colorado, 1966-1994" (paper presented at the annual meeting of the Western Political Science Association, Tucson, Az, March 1997); Todd Donovan, Shaun Bowler, David McCuan, and Ken Hernandez, "Contending Players and Strategies: Opposition Advantages in Initiative Campaigns," In Citizens as Legislators: Direct Democracy in the United States, Eds. Todd Donovan, Shaun Bowler, and Caroline Tolbert, Columbus: Ohio State University Press, (1998) pgs. 80-104.
} 
with broad appeal while spending very little. Conveptually, this must also be built into the model or it will distort the findings to make the resources of Yes groups and broad groups appear more effective than they actually were.

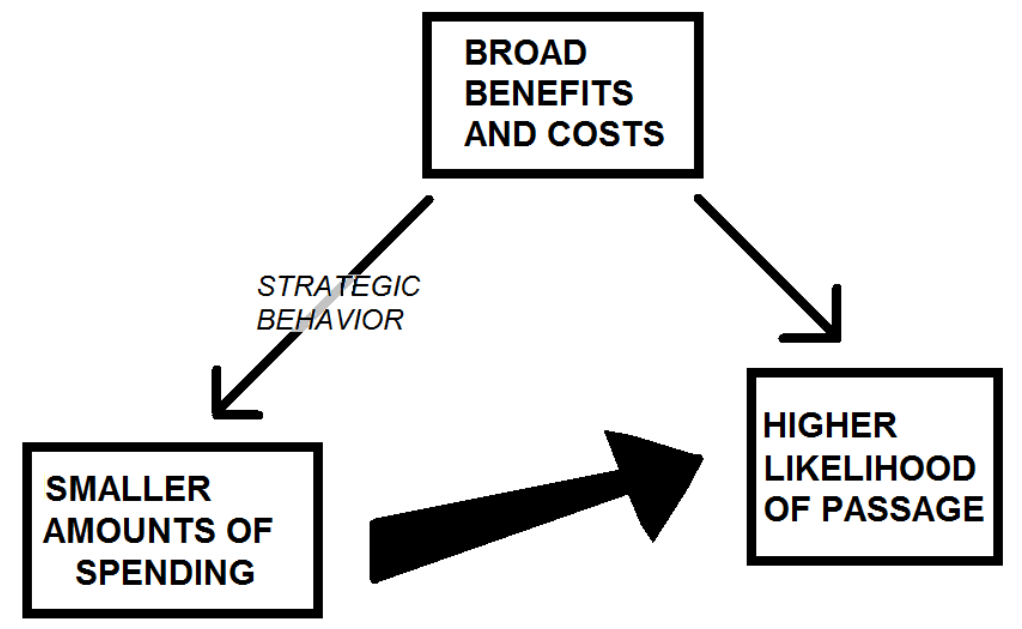

FIGURE 2.1.4: Recurrent situation where broad groups spend small on initiatives with large early majorities for passage

Following this logic, de Figueiredo et al. conducted a two-stage model in similar fashion to Banducci. Their model predicts spending levels in the first stage based on the scope and magnitude of the costs and benefits associated with each initiative. Their research design yielded findings that cut against the previous consensus that initiative contest spending was muted and asymmetric in its effectiveness.

Like the previous authors who designed against the endogeneity problem, de Figueiredo et al. found significant and symmetrical effects for both Yes and No spending. They constructed a "final model... [which predicts that] spending an additional $\$ 100,000$ in support of an initiative increases its chances of passing by a predicted 1.43 percent, 
which is almost as large as the 1.90 percent decrease in the initial likelihood of passage that would result from an additional $\$ 100,0000$ of opposition spending."

This author is a little critical of the conclusions that de Figueiredo et al. draw from their calculations. Though these sorts of numbers indicate that spending could have meaningful effects in extremely tight races, it also suggests that money is only meaningful on the margins and that a broader set of circumstances is actually responsible for determining whether the contest is anywhere near the level of tightness where measure committees can realistically spend their way to victory.

As this literature review has so far demonstrated, Banducci, Stratmann, and de Figueiredo et al. broke with the past and employed sophisticated nonexperimental research designs to counter the endogeneity problem they recognized in the literature. Interestingly, all who have made explicit efforts to account for the endogeneity problem in recent years have found significant and symmetrical effects for ballot initiative contest spending. Recently, Todd Rogers and Joel Middleton's 2012 study tackled the endogeneity dilemma through an experimental research design. A precinct-randomized field experiment was conducted on the influence of a ballot measure committee (initiative contest-oriented PACs) upon initiative outcomes.

Rogers and Middleton's novel and genuinely experimental approach involved collaboration with a PAC (Defend Oregon) that sought to sway the outcome of twelve ballot initiative contests in the 2008 general election in Oregon. The PAC sent between one and two informative ballot guides to most households in the state. The experiment

\footnotetext{
${ }^{42}$ de Figueiredo et al, "Financing Direct Democracy," pgs. 3-4.
} 
involved randomly assigning 200 out of the 700 precincts to a control group who did not receive the intervention in the form of Defend Oregon's informative literature.

Vote margin was Rogers and Middleton's main dependent variable. They used regression to estimate the average change in precinct-level vote attributable to the treatment. They estimated the models using ordinary least squares regression. ${ }^{43}$ The authors found that the treatment had sizable effects in the intended direction on the vote margin for 10 of the 12 ballot initiatives. "Effects on vote margin ranged from 2.5 percentage points to 6 percentage points. Interestingly, the only 2 (of 12) contests where the treatment was judged to be not statistically effective were also the only two ballot initiatives judged to be essentially uncontested in terms of campaign activity.

The results of Rogers and Middleton's 2012 experiment added to a growing body of evidence suggesting a more significant and symmetrical causal role for campaign spending in ballot initiative contest outcomes than was previously understood to be the case. However, one needs to be cautious in making the inductive jump from the observed effectiveness of Defend Oregon's informative pamphlet to the general effectiveness of campaign spending. The context-dependent nature of data limits the sorts of conclusions one can soundly draw from it.

\section{Voter decision-making:}

On a microfoundational level, the debates between scholars on the proper methods for measuring the effectiveness of ballot initiative contest spending are

\footnotetext{
${ }^{43}$ Todd T. Rogers and Joel A. Middleton, "Are Ballot Initiatives Influenced by the Campaigns of Independent Groups? A Precinct-Randomized Field Experiment,” HKS Faculty Research Working Paper Series, RWP12-049, (November 2012) p. 12.
} 
conducted in the shadow of another question: how capable are voters in making choices that are consistent with their interests and values? The voter competence literature pertains to that social process-arrow in the causal-mechanistic explanatory model (see Figures 1.1 and 1.2). How do goal-directed voters make choices in ballot initiative contests in an environment with multiple competing sources of information and rhetoric?

In their 1998 book Demanding Choices, Shaun Bowler and Todd Donovan examine whether and how voters are capable of performing the demanding task of accurately expressing their interests and values through voting in ballot initiative contests. ${ }^{44}$ In line with the conventional wisdom, they found spending against a proposition was associated with greater negative voting,${ }^{45}$ and there was no evidence of a significant relationship between affirmative campaign expenditure and voting in favor of initiatives. ${ }^{46}$ However, Donovan and Bowler's innovation was to gesture towards a more sophisticated model of the micro-mechanisms connecting campaign expenditures to a voter's initiative contest decision-making. The authors explored the ways in which spending affects opinions in less direct ways than a crude "buying votes" model suggests.

Donovan and Bowler proposed that heavy spending focuses more media and interpersonal discussion on particular initiatives. Thus, increasing the chance that voters will be able to evaluate the proposal within one of the standing conceptual frameworks they already possess. Instead of converting opinions, highly contested campaigns are said

\footnotetext{
${ }^{44}$ Donovan and Bowler, Demanding Choices.

${ }^{45}$ Ibid, p. 53.

${ }^{46}$ Ibid, p. 148.
} 
to enhance the voter's ability to answer questions such as "who's behind it?" and "what's in it for me?",47

High spending on any side increases the availability of free cues, independent of the paid campaigns, which prevent heavy one-sided spending from ensuring passage. High overall spending fosters public awareness of whether a small number of clearly identifiable groups or firms are involved in a campaign. ${ }^{48}$ In this way, the Donovan and Bowler build upon John Zaller's insight that the effects of values on political attitudes are not automatic, but rely on elite cues for motivation. ${ }^{49}$

The indirect effects of campaign spending that Donovan and Bowler postulate in Demanding Choices, may stem from the fact that overall spending drives overall awareness. Larger-scale spending may occasionally have paradoxical effect of provoking a backlash, raising opposition to a given proposition. In their own way, Donovan and Bowler affirm the asymmetrical effects framework, stating that well-funded groups are able to influence outcomes, but their influence appears to be much more capable of generating defensive-No votes than affirmative Yes votes. An effective No campaign can generate enough doubt and information overload that voters are driven to pick the safety of the status quo as a default.

However, suggesting the larger ineffectiveness of campaign money to buy initiative outcomes, Donovan and Bowler explain how spending by either side will generate discussion that cements opinion into fixed cleavages, generating more public

\footnotetext{
${ }^{47}$ Ibid, p. 149.

${ }^{48}$ Ibid., 152.

${ }^{49}$ John Zaller, The Nature and Origins of Mass Opinion, Cambridge: Cambridge University Press, (1992) p.57.
} 
cues that allow voters to evaluate proposals through the frame of enduring ideological and party affiliated criterion. Donovan and Bowler paint a picture of a risk-averse voter who is empowered, but also sometimes overwhelmed, by the information generated by campaigns spending. Influentially, Donovan and Bowler captured how initiative entrepreneurs are involved in exploiting, not transforming, the political realities of the moment.

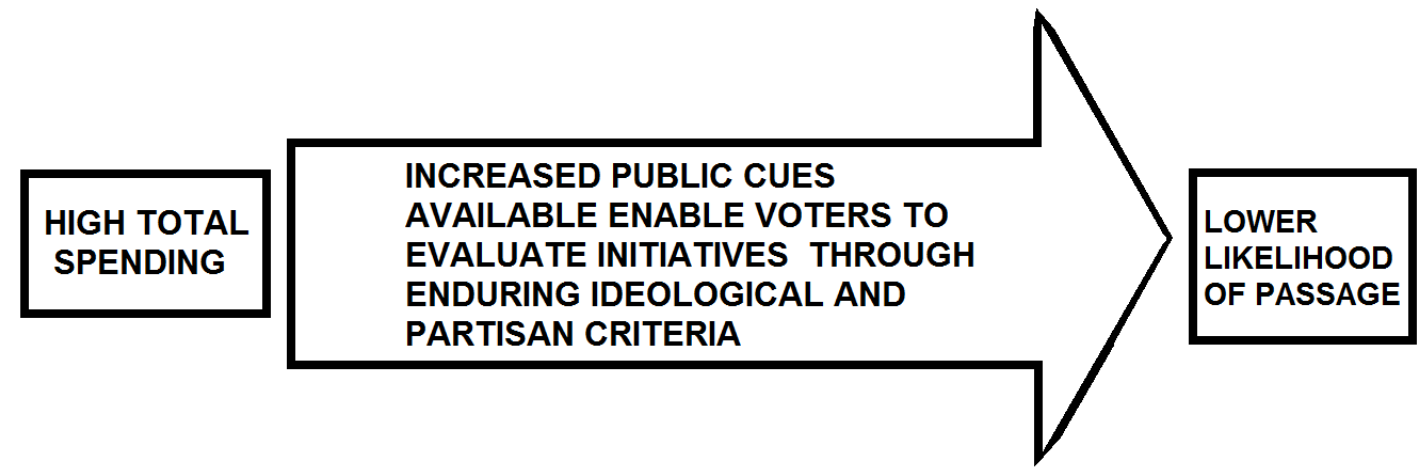

FIGURE 2.1.5: Bowler and Donovan's explanation of asymmetric effects, riskaverse voters, and status quo bias in the initiative process

\section{Conclusions:}

Looking back on the most recent study in this Literature Review, the Rogers and Middleton (2012) experiment finally promised to overcome some of the inherent limitations of the quasi-experimental designs to which past studies had been almost completely limited. Though somewhat illuminating, there still remain numerous critical limitations on the potential to generalize from the results of Rogers and Middleton's experiment to a general confirmation of the effectiveness of Yes spending in persuading voters to approve passage. In a self-published 2008 piece on "Causing public opinion" by 
Daniel Little, the author presents a critique of a hypothetical study, a study which is similar in some ways to that of Roger and Middleton and many others. ${ }^{50}$

Little begins with the underlying assumption that voters have a "prior set of attitudes towards an issue - perhaps including a large number of 'don't know/don't care' people." This underlying voter sentiment could conceivably be measured with a significant level of validity and a sufficiently stable degree of reliability. Next, conceptually, Yes and No campaigns are mounted to lobby the public pro and con. Then, on Election Day, voters indicate their approval in proportions that are often markedly different from the approval distribution indicated by the initial measurement of underlying voter sentiment.

Little's piece notes how, upon initial inspection, the situation appears to be "potentially a very simple area for causal reasoning." Via Little, the situation's initial explanatory potential comes from several elements: 1) the highly and consistently observable outcome variables, 2) the presence of interventions that are usually observable as well, both in terms of timing and magnitude. Moreover, 3) if a researcher has a sufficiently large number of measurements from which to draw inferences, they will establish support for an assumption that an observed correlation probably was not caused by random variation in the variables.

After laying out the strengths of his hypothetical initiative contest outcome research design, Little argued that results from it could not credibly establish that a group caused a change in the outcome a contest. Little identifies all of the elements for reaching

\footnotetext{
${ }^{50}$ Daniel Little, "Causing public opinion," Understanding Society, accessed online on September $16^{\text {th }}, 2013$ (Published Nov. 7, 2008).
} 
a solid piece of "singular causal reasoning" about "one population, one issue, and a specific set of interventions." However, the situation lacks that "which would be needed in order to arrive at a conclusion of generic scope." The external validity becomes increasingly tenuous as the purpose of the research design moves from explaining the effects of money in specific situations towards research designs intended to support more general claims about the universal causal properties of campaign spending.

To overcomes these kind of external validity problems without compromising the scope of one's explanatory goals, Little prescribes a research plan re-design which incorporates a more extended set of cases in which a greater variety of strategies are likely to be seen coming into play. However, even when the sample is large and diverse in one of Little's hypothetical experiments, he argues a researcher should reconsider the validity of using "this body of data... [to] arrive at estimates of the relative efficacy of [different] treatments." A trade-off is made as the sample expands and discrete situations are collapsed into a single artificially homogeneous category.

In this brief and incisive piece of online philosophy of social science analysis, the bottom-line question is whether the resources exist to perform a study of initiative contest outcome causality that can "provide guidance for other campaigns over other issues in other places." Little casts doubt on the possibility of providing such context-independent, transportable guidance. He points to stubborn explanatory limits which plague attempts at vigorously establishing broad evidence of the basic properties of "causing public opinion." 
Little's critique explains why this Literature Review reaches the conclusion that, when research looks solely to quantify the significance of campaign spending as an explanation of initiative contest outcomes, it ignores the immutable heterogeneity of modes and forms of campaign expenditures (interventions). What is more, it ignores the contingencies which enable and contain the effects of money. A very large and diverse sample is needed to reach broadly generalizable estimates of the effect of campaign spending. However, gains made in parsimony come hand-in-hand with a degree of blindness to the important contingencies and heterogeneity that structure the data.

Upon reviewing the Approach \#1 literature, this author finds the explanations of money, even when seemingly sound from an econometric perspective, offer an insular and impoverished explanation of the deeper causes of contest outcomes. Those studies that do manage to capture the econometrics properly though, like de Figueiredo et al.'s 2011 study, do so by grounding their data in controls built from instrumental variables which speak to a deeper layer of causal narratives. Some of these instrumental variable sets come from the cost-benefit distribution of particular initiatives, which will be the topic of this next section on Approach \#2.

In the next section on Approach \#2, this Literature Review will examine a group of scholars who look explicitly at the connection between the internal characteristics of a group and the strategies that groups leverage to secure their desired initiative contest outcomes.

\section{Explanatory Approach \#2: Cost-benefit distribution}


In the previous section, a group of scholars were featured who transformed the literature on the effectiveness of money by confronting the endogeneity of campaign spending to ballot initiative contest outcomes. They did so by tracing the causal influence of money backwards, deeper into the causal relationship to ask the question, "Why do some ballot initiative campaigns have more money than others in the first place?" The first stage of de Figueiredo et al.'s 2011 research model is based on the cost-benefit distribution at stake in a given initiative contest. Those authors were building upon the insights of the researchers examined in this section of the Literature Review.

Do policy-demanding individuals and groups find political leverage in the costbenefit distribution at stake in a given initiative contest? Does the initiative process the present a tool for narrow economic interests to "buy" preferred policy? Or is it the other way around: Do broad-based citizen groups leverage the ballot initiative process to overcome collective action problems and secure policy-demands with broad appeal? This Approach \#2 section will cover a body of the literature that explains ballot initiative successes through the internal characteristics of policy-demanding groups and the relative concentration or diffusion of the costs and benefits at stake.

The Approach \#2 section of the literature review begins with some background on collective action problems and the concepts of breadth and narrowness of costs and benefits associated with particular initiatives. The idea is that different political dynamics characterize the conflicts between affirmative and oppositional initiative advocates. These political dynamics are based on the relative concentration or diffusion, as well as the magnitude of cost and benefit at stake in a contest. 
These costs and benefits are supposedly embodied in the substance of policies under this approach. Studies will be examined that categorize initiative contests within a 4-type system based on the four "political situations" associated with cost-benefit distribution among Yes and No demanding actors. The Approach \#2 literature review then examines work on the differences in the operations and effectiveness of different types of policy-demanding individuals and groups. Elizabeth Gerber's research will be examined, which classifies citizen interest groups and economic interest groups within the initiative arena. Also examined will be the work of those researchers who built upon her insights. Emphasis is put on Gerber's assertion that the initiative process is a site where broad "citizens group" can leverage a comparative advantage they possess in terms of their personnel power. Broad interests do indeed appear to wield some sort of competitive advantage in the ballot initiative arena. The exact mechanism behind this remains an open question.

\section{Collective action problems}

The American tradition of political thought is deeply influenced by the arguments of James Madison. Madison highlighted a fundamental problem facing all democracies; designing governments in such a manner as to provide for stability, energy, and liberty. For Madison, the greatest threat to a democracy came from the destabilizing potential of mass participation in government. Madison advocated for a system of government that maintained a balance between the energetic dynamism brought about by mass participation and the stability provided through checks, balances, and a representative 
form of government. As Elizabeth Gerber put it, "all across America and at all levels of government, the institutionalization of Madisonian ideals limited the power of the majority." $" 51$

Mancur Olson's pivotal 1965 book, The Logic of Collective Action, blazed the path for what is now arguably an entire paradigm of political science that draws on a distinctly economistic mode of explanation. Olson's work was based on a theory of concentrated benefits versus diffuse costs. Groups, via Olson, are defined by the interests which animate them. The characteristics of a group's animating interest define a group's internal characteristics. In turn, the internal characteristics of a group determine the strategies and resources available to it.

Via Olson's account, groups acting to protect diffuse interests are systemically plagued by collective action problems caused by the incentive to free ride. In contrast, groups seeking narrowly concentrated benefits will find that their situation is much more conducive to coordinating collective action to achieve their goals. Olson's main theme is the difficulty that groups have cooperating without coercion to control them. The larger the group, the less excludible the stakes involved, the less probability that group members can be motivated to take action.

Olson's argument carries major implications for the logic underlying Madisonian political institutions. Via Madison, in a democracy, the most significant concern is that a majority will tyrannize and exploit the minority. Via Olson, the critical concern becomes that a well-organized minority will find itself able to enact policies which cut against the interests of broad majorities. Olson's logic suggests that narrow, well-organized

\footnotetext{
${ }^{51}$ Elizabeth Gerber, The Populist Paradox, p. 3.
} 
majorities will secure the enactment of policies that deliver narrow benefits and impose broad costs. Perhaps, in light of Olson's findings, institutions would be better organized to guard against the potential for narrow factions to exploit the distortions of representative government in order to "tyrannize" the majority. The ballot initiative is the sort of non-Madisonian institution that might mitigate the undesirable distortions caused by the perverse logic of collective action.

In a 1972 journal article, Theodore Lowi drew attention to the relationship between the substance of policies and the sorts of political mobilization that occurred to support or oppose them. ${ }^{52}$ Lowi created a three-category scheme for classifying policies according to the cost-benefit distribution that would occur as a result of their enactment. Via Lowi, "Policies determine politics." ${ }^{, 53}$ James Q. Wilson's 1980 book, The Politics of Regulation, would build on this important theoretical insight. ${ }^{54}$ Wilson's cost-benefit distribution typology describes "four political situations" that result from four different types of policies. Wilson's typology is displayed below in Figure 2.2.1

\footnotetext{
${ }^{52}$ Theodore J. Lowi, "Four Systems of Policy, Politics, and Choice," Public Administration Review, Vol. 32, No. 4, (1972) pgs. 298-310.

${ }^{53}$ Ibid, p. 299.

${ }^{54}$ James Q. Wilson, The Politics of Regulation, 1980
} 


\section{COST DISTRIBUTION}

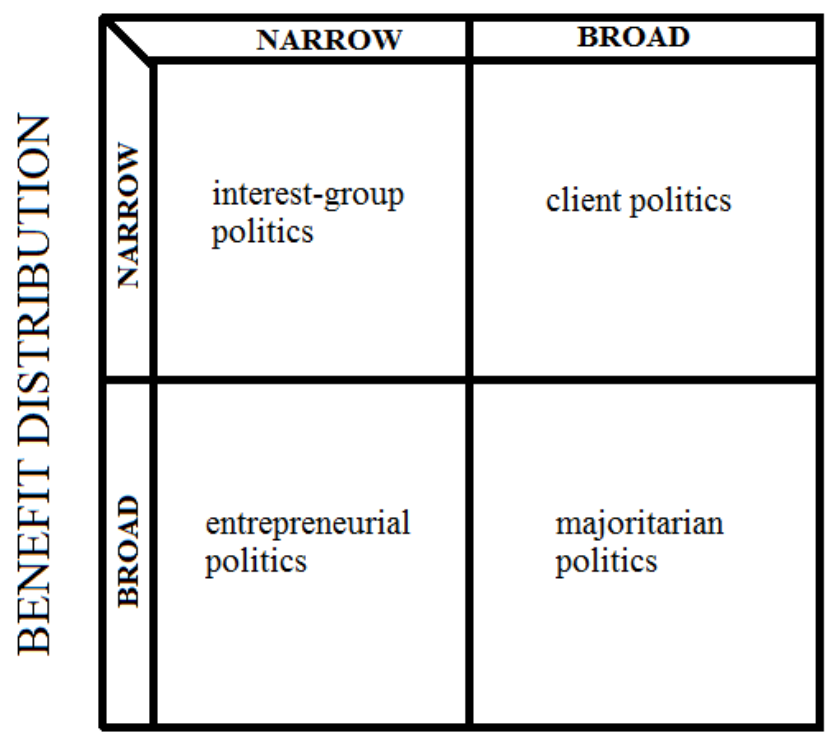

FIGURE 2.2.1: Wilson's typology of policies and political situations

Writing in 1980, Wilson sought to explain the passage of "new or social regulations" of the 1960s and 1970s in the realm of environmental-protection laws and auto-safety rules. Olson's logic of group action had suggested the apparent improbability of such regulatory action, taken where the benefits of action were broadly diffused and the costs were narrowly concentrated.

Wilson applied his typology in the context of bureaucratic politics. He traced the political motives that shaped the demand for business regulation as well as the conditions of business capture. But, decades later, Wilson's schematic would be transported to the study of state ballot initiative politics. In an unpublished paper presented at a political science conference in 1997, Anne Campbell first introduced the Wilson typology into the 
context of ballot initiative contests. ${ }^{55}$ As Campbell revealed, ballot initiative politics are distinctly fertile soil for Wilsonian analysis because the contests are each attachable to the acceptance or rejection of a defined policy option.

Campbell's data set included the 57 statewide initiatives voted on by Coloradans between 1966 and 1994, as classified using Wilson's two-by-two policy matrix. Campbell assigned the initiatives to the categories based on her "assessment of the most likely and immediate consequences of the passage of an initiative, in terms of whether the general public or specific interests would bear the economic, political, and/or social costs and benefits." ${ }^{56}$ The assessment was informed by the author's review of the initiatives themselves, as well as newspaper articles and editorials, and the arguments set forth in the nonpartisan informative literature prepared by the Colorado Legislative Council.

Campbell began her research with several specific hypotheses. These hypotheses were informed by her broader "proposal that the initiative process is not conducive to... [abuse] by wealthy individuals and special interests... and that it should therefore serve primarily as a means of serving the public interest rather than private interests. ${ }^{, 57}$ Her first hypothesis was that there would be significantly more entrepreneurial and majoritarian initiatives (broad Yes side) combined than there were client and interest group initiatives (narrow Yes side). This hypothesis was confirmed by her findings wherein two-thirds of the 57 initiatives aimed to enact policies which sought general

\footnotetext{
${ }^{55}$ Anne Campbell, “The Citizen's Initiative and Entrepreneurial Politics: Direct Democracy in Colorado, 1966-1994," (paper presented at the annual meeting of the Western Political Science Association, Tucson, Az, March 1997).

${ }^{56}$ Ibid, p.8.

${ }^{57}$ Ibid, p.10.
} 
public benefits. ${ }^{58}$ Campbell also found the highest voting rates within client and majoritarian contests, suggesting to her that "voters are more interested and knowledgeable about the issues for which they will have to bear the costs."59

Campbell's final hypothesis regarded the pattern of success rates for the different types of initiatives. True to her hypothesis, Campbell found the highest success rate for majoritarian initiatives, followed by entrepreneurial initiatives in second place.

"Basically," Campbell wrote, "one half of entrepreneurial and majoritarian initiatives passed, compared to $37 \%$ of all initiatives. ${ }^{\prime 60}$ Client politics initiative contests were found to be the least likely to pass. Only 8 percent (1 out of 12) of the clientelistic initiatives passed within Campbell's thirty year Colorado sample.

Campbell's application of the Wilson typology would be repeated in a 1998 book chapter by Todd Donvan, Shaun Bowler, David McCuan, and Ken Fernandez. Like Campbell, these authors found reason to doubt explanations of ballot initiative passage that looked to the financial resources of wealthy, narrow interests. "Despite the escalating costs of direct democracy" campaigns, Donovan et al. observed "that organized groups with modest resources - groups who represent fairly broad, diffuse constituencies - d continue to place measures on the ballot that do pass... A respectable proportion of these measures pass in spite of the fact that they threaten well-organized, wealthy interests who wage expensive opposition campaigns. ${ }^{, 61}$ Donovan et al. examined the factors that allow

\footnotetext{
${ }^{58}$ Ibid, p. 25.

${ }^{59}$ Ibid, p.13.

${ }^{60}$ Ibid, p. 18.

${ }^{61}$ Donovan et al.,"Contending Players and Strategies."
} 
these "fairly broad, diffuse constituencies" with modest financial resources to successfully challenge wealthy, well-organized interests in the initiative arena.

Following Campbell's approach, Donovan et al. classified initiatives into the four categories from Wilson's typology. Donovan et al. looked at 53 ballot initiatives that appeared on California General Election ballots between 1986 and 1996. Echoing Campbell's results, Donovan et al. found that clientelistic-type initiatives were the least likely to pass. Speaking to the asymmetry literature, the authors wrote that "money spent by proponents in this arena is largely wasted."62 Only 14 percent of clientelistic initiatives passed and the average vote for these initiatives was a mere 28 percent in favor. ${ }^{63}$ Interest group politics contests were also found to be very unlikely to end in passage. Just like clientelistic-type initiatives, only 14 percent of interest group initiatives passed, in contrast to a 41.5 percent overall passage rate. Like Campbell's, Donovan et al.'s findings suggest that the ballot initiative process displays a recurrent pattern wherein broad, diffuse interests tend to hold an advantage over narrow, excludible interests.

Campbell found in her 1997 study that two-thirds of the initiatives in her sample involved broadly diffused benefits for Yes sides (entrepreneurial and majoritarian initiatives). ${ }^{64}$ Donovan et al. similarly found that almost three-fourths of the initiatives in their sample would benefit broadly-based consistencies. However, whereas Campbell placed the majority (54 percent) of her initiatives in the entrepreneurial category, Donovan et al. placed the plurality (47 percent) of their initiatives in the majoritarian

\footnotetext{
${ }^{62}$ Ibid, p. 92.

${ }^{63}$ Ibid, p. 92-93.

${ }^{64}$ Campbell, "The Citizens Initiative and Entrepreneurial Politics," p. 12.
} 
category. ${ }^{65}$ In contrast to all other types of initiatives in the Donovan et al. study, a clear majority (58 percent) of majoritarian contests ended in passage.

In a 2005 book chapter titled "Can’t Buy Me Love," David McCuan would expand upon his use of the Wilson typology in the 1997 piece with Donovan, Bowler, and Fernandez. McCuan's focus this time around was on the professionalization of a ballot initiative system that was originally "designed as a process for amateurs to work around powerful, entrenched interests. ${ }^{, 66}$ McCuan categorized ballot initiatives using the Wilson typology and a data set made up of all 93 citizens' initiatives that appeared on the California ballot from 1984 through 1998. The typology was supplemented by an analysis of how campaigns actually spend campaign dollars, listed in categories including media and print advertising, professional consulting expenditures, cash transfers to other campaigns, and other categories.

Like Campbell and Donovan et al., McCuan's 2005 study found over two-thirds of all initiative contests featured broad Yes sides. In keeping with his earlier work with Donovan et al., McCuan found a plurality of all contests (47 percent) to fit into the majoritarian category. ${ }^{67}$ In sharp contrast to all other contest, 60 percent of majoritarian contests ended in passage. This made majoritarian initiatives 3 times more likely to succeed than the next most successful type (entrepreneurial).

\footnotetext{
${ }^{65}$ Donovan et al., "Contending Players and Strategies," p. 90.

${ }^{66}$ David McCuan, "Can't Buy Me Love: Interest Group Status and the Role of Political Professionals in Direct Democracy," In Initiative-Centered Politics: The New Politics of Direct Democracy, Eds. David McCuan and Steve Stambough, Durham: Carolina Academic Press, (2005) p. 52.

${ }^{67}$ Ibid, 2005 p. 68
} 
This literature review has devoted so much attention to the findings of initiative scholars who used the Wilson typology because it is part of the research design included under Methods (Chapter 3).

\section{Citizen groups, economic groups, and initiative politics}

In her 1999 book on direct legislation, Elisabeth R. Gerber argued that it was "a mistake to equate money with influence in the context of" ballot initiative contests. "Big spending," Gerber wrote, “does not imply big influence.",68 Gerber presented evidence that different types of policy-demanders sought different types of influence in the direct legislation process. Her work acknowledges the multiplicity of interest groups and considers the differences between several different types of groups (economic vs. citizen, wealthy vs. less wealthy, narrow vs. broad-based). For Gerber, "the very existence of such diverse groups is a function of their internal characteristics and their ability to overcome inherent hurdles." ${ }^{, 69}$ She traces how a group's internal characteristics determine the strategies it chooses.

Gerber's work is based on a conceptual premise that considers interest groups in the ballot initiative process as "analogous to profit-maximizing firms as they are characterized in microeconomics... [because] like firms, an interest group's resources determine which political strategies it can afford to pursue and whether the interest group achieves its goals" ${ }^{70}$ Gerber's profit-maximizing firm analogy is useful because it

\footnotetext{
${ }^{68}$ Gerber, The Populist Paradox, p. 6.

${ }^{69}$ Ibid, p. 13.

${ }^{70}$ Ibid, p. 7.
} 
emphasizes the constrained maximization problem that confronts both firms and interest groups.

Gerber borrows the concept of comparative advantage from the economic literature. Just as firms attempt to maximize profits by choosing between alternative modes of production (i.e., capital intensive or labor intensive), "interest groups have comparative advantages in mobilizing the different resources required by direct legislation strategies." ${ }^{71}$ An interest group's ability to mobilize monetary and personnel resources is determined by its membership composition.

Membership composition determines the nature of a group's collective action problem. "Groups whose members are primarily firms and organizational representatives can more easily mobilize monetary resources, whereas groups whose members are primarily autonomous individuals can more easily mobilize personnel resources." 73 Gerber argued that the ballot initiative process presents a competitive advantage for those groups who hold an advantage in mobilizing personnel resources.

In terms of data, Gerber relied on two main sources. First, she collected and synthesized campaign finance reports from four different states (California, Idaho, Nebraska, and Oregon) over a four year period (1988-1992). Secondly, she drew upon the results of a survey she conducted in the spring of 1996. The survey was mailed to 600 interest groups that were active in initiative contests and candidate races between 1988 and 1992 in the same four states from which the campaign finance data was drawn. Half of the surveys were sent to groups who sought to affect the outcome of ballot initiative

${ }^{71}$ Ibid, p.8.

${ }^{72}$ Ibid, p. 65.

${ }^{73}$ Ibid. 
contests. The other half of the surveys were sent to groups who contributed to statewide candidate races but stayed financially removed from initiative politics. 156 surveys were returned to Gerber completed, making for a response rate of about $26 \%$.

Central to Gerber's analysis is a distinction between "citizen interests" and "economic interests." 74 Citizen interests are represented by the activities of citizens groups, occupational groups, and individuals, whereas economic interests are represented by the activities of economic interest groups, professional groups, and businesses. In this context of Approach \#2, “citizen interests" represent broad-based interests and diffuse benefits. "Economic interests" represent narrow interests and private, concentrated benefits.

From her analysis of the survey responses, Gerber found that citizen interests were significantly more likely to finance Yes campaigns and report assigning a greater level of importance to passing new laws by initiative. ${ }^{75}$ Economic interests, on the other hand, were found to be much more likely to either only engage in the initiative process defensively (financing No campaigns) or to use the initiative process in pursuit of indirect influence, meaning their goal was not to achieve passage through the initiative process directly but rather to signal and pressure the legislature.

From the campaign finance data, Gerber finds evidence to support her hypothesis and corroborate her analysis of the survey responses. Within the time period and states examined, Gerber found economic interests directed an overwhelming share of their contributions (74 percent) to No campaigns rather than to supporting Yes campaigns (26

\footnotetext{
${ }^{74}$ Ibid, p.83.

${ }^{75}$ Ibid, p. 83 .
} 
percent). Conversely, Gerber found that citizens' interests directed an equally greater share of their contributions (72 percent) to supporting Yes campaigns rather than opposing initiatives. Overall, Gerber explains ballot initiative success as the result of broad-based citizen groups leveraging their personnel power to pass ballot initiatives. Diffuse interests use the initiative process to help overcome collective action problems.

The results Gerber came to must be discounted to the degree across-group differences in survey response patterns limit the statistical significance she measures. Additionally, testing her theories about personnel advantages versus financial advantages becomes a bit of a moving target when we consider the evolving nature of communication technologies and regulations surrounding the process. Technological changes are capable of transforming the relative importance of personnel advantages in ballot initiative contests.

Gerber's work built on a congressional literature that had long interrogated the composition of contributions to candidate campaigns. What factors caused the contribution levels that made massive spending efforts possible? If the literature suggested money could not buy influence then why was so much money spent? Or, alternatively, if the literature reflected that money could significantly impact outcomes, then why was so little money spent in politics?

A 2002 article by Stephen Ansolabehere, John de Figueiredo, and James Snyder, the authors considered why, in light of the enormous value of public policies at stake, was there so little money in U.S. politics. The authors "argue that campaign contributions are not a form of policy-buying, but rather a form of political participation and 
consumption." 76 The authors use descriptive statistics and an econometric analysis to provide evidence that campaign spending is a "normal good dependent upon income."

First the authors demonstrate that almost all campaign money comes in the form of 'hard' contributions that must abide by limitations. ${ }^{77}$ Then analysis was performed on the 1999-2000 election cycle. Of the $\$ 3$ billion raised by candidates and party committees, "individuals contributed nearly $\$ 2.4$ billion, the public treasury paid $\$ 235$ million, and about $\$ 380$ million came directly from the treasuries of corporations, unions, and other associations." 78 The authors concluded that, for candidate races, "individuals are by far the largest and most important source of campaign funds."79

Ansolabehere et al. theorized that campaign contributions mainly represent consumption and participation. They test their theory against the rent-seeking models which predict that total government spending should explain total campaign spending. The results indicated that income was a better predictor of contributing than growth of government, supporting their consumption model and weakening the rent-seeking models.

Gerber's (1999) findings about the relatively greater effectiveness of spending by citizen groups would receive a fuller empirical and theoretical foundation in the form of a 2004 study of candidate elections by Stephen Coate. ${ }^{80}$ Coate's model implied that voter's evaluations of candidates are influenced by the sources of candidates' campaign funds. Coate provided evidences that voters elect the high-quality candidate substantially less

\footnotetext{
${ }^{76}$ Ansolabehere et al., "Why is There so Little Money in U.S. Politics?" p. 2.

${ }^{77}$ Ibid, p. 10.

${ }^{78}$ Ibid.

${ }^{79}$ Ibid, p. 12.

${ }^{80}$ Stephen Coate, "Pareto Improving Campaign Finance Policy," American Economic Review, Vol. 94, No. 3, (2004) pgs. 628-655.
} 
often when his or her campaign is financed by special interests. This type of voter evaluation of contributor-types might provide a mechanism through which to explain the relative ineffectiveness of economic interest group spending observed by Gerber.

The question remains open as to whether the different sources of campaign finance have distinct impacts on voter behavior in initiative contests. In a 2005 study, Richard Braunstein collected spending data from all 78 ballot initiative contests during the the 1998 - 1992 elections in California and Colorado. ${ }^{81}$ Braunstein coded each of the contributors as either individuals or organizations. The author then uses descriptive statistics to show how donor types were distributed across the initiative contests in the sample.

To begin, Braunstein found that in 22 percent of cases, initiative issues received financial support from individuals greater than or equal to the amount received from organizations. Conversely, this means that in an overwhelming majority of cases (78\%), initiatives received the bulk of their financing from organizational sources and not individual donors. Braunstein's findings contrasted with contemporary studies of congressional politics which showed a majority of the money in candidate races came from individuals. ${ }^{82}$ Why would organizations constitute more of the contribution of initiative campaigns when individuals compose the majority of contributions to candidate campaigns? What are the normative implications of this pattern?

\footnotetext{
${ }^{81}$ Richard Braunstein,. "The Impact of Campaign Finance on Ballot Issue Outcomes," in InitiativeCentered Politics: The New Politics of Direct Democracy,” eds. David McCuan and Steve Stambough, (Durham: Carolina Academic Press, 2005) p. 81.

${ }^{82}$ Ansolabehere et al., "Why is There so Little Money in U.S. Politics?"
} 
Braunstein's research found that organizational sources of funding composed a majority of contributions to both Yes committees (58\%) and No committees (78\%). ${ }^{83}$ However, individuals made up over twice the percentage of contributions to Yes committees $(31 \%)$ in comparison to No committees $(15 \%) .{ }^{84}$ This finding reinforces Gerber's conclusion that broad citizen interests are more likely to propose and support initiatives, whereas narrow economic interests are more likely to mount $N o$ campaigns. ${ }^{85}$

A third analysis in the Braunstein study examines passage rates. ${ }^{86}$ The results here were striking. 69.2 percent of individual contributions went into initiative contests that ended in passage. Conversely, $62.3 \%$ of organizational contributions went into contests which ended in failure. This analysis aggregates Yes and No spending into total spending figures. Braunstein's findings suggests, like the earlier work on majoritarian initiative politics,${ }^{87}$ that the initiative process is the site of regular victories for diffuse coalitions of individuals pursuing broad interests.

John G. Matsusaka's 2004 book For the Many or the Few investigated whether the initiative process "makes policy more responsive to the will of the majority or increases the influence of narrow special interests. ${ }^{, 88}$ Matsusaka's empirical strategy involved comparing the fiscal policies of states with and without the initiative process. "The idea," Matsusaka wrote, "is that however the initiative works, directly or indirectly,

${ }^{83}$ Braunstein, “The Impact of Campaign Finance on Ballot Issue Outcomes,” p.84.

84 Ibid.

${ }^{85}$ Gerber, “The Populist Paradox," pgs. 4-7.

${ }^{86}$ Braunstein, p. 85.

${ }^{87}$ Campbell, "The Citizen's Initiative and Entrepreneurial Politics"; Donovan et al., "Contending Players and Strategies"; McCuan, "Can’t Buy Me Love."

${ }^{88}$ Mastsusaka, John G. For the Many or the Few? The Initiative Public Policy, and American Democracy, (Chicago: University of Chicago Press, 2004) p.12. 
the effect (if any) will show up in the final policies. ${ }^{, 89}$ Since taxing and spending policies are influenced by many factors entirely independent of the initiative process, regression analysis was employed to isolate the effect of the initiative. The final part of Matsusaka's analysis involved comparing the policy changes with the expressed opinion of the electorate to determine if a majority of people in each state liked or disliked the change.

Matsusaka focuses on the time period between 1970 and 2000 because this was a period in which the initiative was heavily used. According to Matsusaka, "three systematic effects" of the initiative process emerge from the data. ${ }^{90}$ First, the initiative process reduced overall spending by state and local governments. Secondly, the initiative process shifted spending towards local governments and away from state governments. And finally, the initiative process changed the manner in which funds got raised: "broadbased taxes were cut and replaced with user fees and charges for services." 91

Next, Matsusaka examines whether a majority of citizens supported or opposed the policy changes induced by the initiatives (i.e., lower overall spending, decentralization, and replacing taxes with charges). Matsusaka studied numerous opinion polls over the thirty-year time span in question and found the evidence to be "remarkably consistent: a majority of people supported each of the three policy changes associated with the initiative."92 Matsusaka suggests that "the most natural interpretation of the evidence is that the initiative allows the majority to defend itself against powerful groups that receive favorable treatment in the legislature."

\footnotetext{
${ }^{89}$ Ibid, p. 13.

${ }^{90}$ Ibid.

${ }^{91}$ Ibid.

${ }^{92}$ Ibid.
} 
For Matsusaka, ballot initiatives serve the policy interests of the broadly diffused "many" and not the narrowly concentrated "few." In his model, the initiative process enables majorities to make policy without the permission or cooperation of key actors who control representative institutions of policymaking. None of this is to suggest that the initiative is a policymaking institution that is inherently predisposed to lowering and decentralizing spending. As evidence of this, Matsusaka performs another regression analysis on the early $20^{\text {th }}$ century and finds that, at that earlier time, the presence of the initiative process was associated with high, centralized spending and taxation. The initiative leads to the enactment of policies that are closer to the preferences of the median voter, regardless of the ideological substance of said policy.

This paper's review of Approach \#2 demonstrated what past studies have found about the role that collective action problems play in structuring ballot initiative politics. This section began by examining the dynamics of individual and group behavior taken up in Mancur Olson's work. Via Olson, groups exist to serve shared interests. Groups formed around narrowly concentrated and exclusive interests will find a high capacity for coordination and cooperation. Accordingly, group efforts to secure broadly enjoyed, nonexcludible collective goods will be plagued by collective action problems.

For over 20 years, a consensus has been accumulating that the ballot initiative process is characterized by a competitive advantage for broad interests. Authors have repeatedly identified high occurrences and high passage rates for initiative contests where both broad costs and broad benefits are at stake ("Majoritarian Politics"-type situations). Political science needs to go further in unpacking the implications of these findings. 
What is the exact mechanism behind a competitive advantage for broad, "citizens groups?" Gerber identifies it as a simple matter of a personnel advantage for broad citizens groups, alongside a financial advantage enjoyed by narrow business groups. Put simply: manpower held more purchase in the initiative process and financial power was a greater asset when trying to push policy change through a legislature. How does one know it is manpower that is making campaigns successful and not the broad benefits of the proposed policy that inspired the manpower to begin with? Additionally, changes in technology and the campaigning landscape could be changing the relative power of a personnel advantage, as new technology and communication breakthroughs transform the relevance of personnel power in a ballot initiative contest from start to finish.

\section{Approach \#3: Institutionally-embedded explanations}

The Approach \#3 section of the Literature Review begins with a discussion of what constitutes an institutionally-embedded explanation of an initiative contest outcome. The section then provides background on the theoretical foundations of the initiative process as a policymaking institution. Studies will be examined which place initiatives into the context of the system of partisan attachments within the electorate which reliably structures voting decisions in candidate races. This section ends with a discussion of the importance of nonpassage goals to initiative actors and the limitation of passage models that exclude them. 


\section{Institutionally-embedded explanations}

So far, this literature review has examined the camp of academic research on explaining the role of money in initiative contest outcomes, as well as another camp which explains outcomes in terms of the costs and benefits that an initiative offers. The Literature Review now concludes with a final, and, this author argues, a critical layer of what a satisfying passage explanation must contain. Approach \#3 incorporates what the author calls "institutionally-embedded explanations."

An institutionally-embedded explanation is any causal argument that grounds its microexplanations (of individual behavior) or its macroexplanations (of larger aggregated social phenomenon) in mesoexplanations which draw upon the roles, routines, norms, and identities of ['institutions'] to build causal arguments. ${ }^{93}$

Microfoundational, ${ }^{94}$ microexplanations ground the pursuit of answers to "why?" questions in the behavior of individual goal-directed agents. Olson's logic of free-riding is a form of microexplanation. Macroexplanations use a highly-aggregated level of individual behaviors to explain social phenomenon in terms of large social macro-factors. An illustrative example of a macroexplanation is Max Weber's argument about the connection between Protestant values and capitalism. ${ }^{95}$ In between the two extremes lie mesoexplanations, wherein micro- and macroexplanations are reinforced or challenged by the causal powers belonging to organizations and institutions.

\footnotetext{
${ }^{93}$ James G. March and John P. Olsen, "Elaborating the 'New Institutionalism,"” The Oxford Handbook of Political Institutions, accessed online through Oxford Handbooks Online (June 2008).

${ }^{94}$ Little, Varieties of Social Explanation.

95 James Coleman, Foundations of Social Control, Cambridge: Belknap Press of Harvard University, (1998); Daniel Little, "Explanatory Autonomy and Coleman's Boat," Theoria, (2012).
} 
Philosopher of social science Daniel Little argues for the significance of organizations and meso-level factors to social explanation. Little claims that "meso entities (organizations, institutions, normative systems) often have stable characteristics with regular behavioral consequences." Incentives, sanctions, and supervision are implemented differently across different organizations. Various institutional forms may be more or less efficient at performing certain tasks, determining consequences for the people and higher-level organizations which depend on them.

James G. March and Johan P. Olsen provide a similar account in their 2008 piece written to elaborate "the 'New Insititutionalism." ${ }^{\prime 96}$ The authors' focus in the piece is on the elements of order and predictability that institutions can provide. The essay unpacks the explanatory potential of the "new" institutionalist explanations. In keeping with Little's assessment, the authors observe that 'the 'new institutionalism' avoids unfeasible assumptions that require too much of political actors in terms of normative commitments... cognitive abilities... and social control. The roles, routines, norms, and identities of an 'institution,' rather than micro-rational individuals or macro-social forces, are the basic units of analysis." 97

March and Olsen grant the complexity of the causal relation between institutional arrangements and substantive policy outcomes. Causal claims are usually indirect, long, and contingent. ${ }^{98}$ The Approach \#3 section aims to demonstrate the explanatory value of embedding explanations of initiative passage in a larger institutional context. Doing so

\footnotetext{
${ }^{96}$ March and Olsen, "Elaborating the 'New Institutionalism.",

97 Ibid.

${ }^{98}$ R. Kent Weaver and Bert A. Rockman, "Do Institutions Matter? Government Capabilities in the United States and Abroad," Washington DC: The Brookings Institution (1993).
} 
helps to construct expectation of how initiative contest outcomes are constrained and enabled by political institutions, even if those institutions aren't necessarily the immediate and direct cause of policy change.

David McCuan and Steve Stambough authored a 2005 book whose overall theme was an understanding of the initiative process as one among many state policymaking institutions, “a 'parallel legislature,' incumbent with the problems and challenges we see in the 'sausage-making' process... [of] legislative politics." 99 Though noting, "clear and compelling differences in the process associated with each arena," the authors insisted that "the challenges of democratic governance are largely the same." The authors go on to identify permanent features and ongoing trends in initiative politics which reproduce the pathologies observed in the representative institutions of policymaking.

This nicely sets the tone for the Approach \#3 section of the literature review, which will examine institutionally-embedded explanations of initiative contest outcomes. These explanations will often speak to McCuan and Stambough's larger question of how an initiative contest compares, contrasts, and interacts with the other policymaking institutions that surround it. Does the initiative mechanism truly "subvert the traditional electioneering function of the party and provide the opportunity for private (i.e., nonparty) organizations to offer advice and conduct campaigns."100

Do different sorts of policy-demanding individuals and groups find success through the initiative process than would without it? How do ballot initiative successes fit into a larger understanding of legislative politics? McCuan and Stambough argued in

\footnotetext{
${ }^{99}$ McCuan and Stambough, Initiative-Centered Politics, p. 4.

${ }^{100}$ Ibid, p. 60.
} 
2005 that "we know [little] about the motivations of groups seeking to do battle through direct democracy when the traditional legislative process remains an avenue of opportunity for so many interest groups."101

\section{Markets, governments, and institutional failures}

Conceptually, this thesis imagines a balance of power between two classes of institutions: market institutions and government institutions. This view is informed by the insights of Jacob Hacker and Paul Pierson (2009?) regarding the government's role in constructing and maintaining markets. ${ }^{102}$ Theoretically, under a liberal regime, the presence of a policy problem indicates the presence of some market failure. The market is the default mechanism for allocating values in regards to the private interactions of autonomous individuals. Under this model, the need for government action would emerge from dissatisfaction with some inefficient allocation which the market generated.

The presence of a policy problem implies some form of market failure is occurring. A policy problem in its simplest form can be understood as "some unrealized gain or avoidable harm" connected to potential failures to satisfactorily allocate values. ${ }^{103}$ Efficiency is not the only dimension upon which an electorate can decide the market has failed. Further evaluative frameworks important to voters include policy effectiveness, policy adequacy, normative ideological commitments, and equity of distributive outcomes.

\footnotetext{
${ }^{101}$ Ibid, p. 7.

102 Jacob S. Hacker and Paul Pierson, Winner-Take-All Politics: How Washington Made the Rich Richerand Turned Its Back on the Middle Class (Boston: Simon \& Schuster, 2011).

${ }^{103}$ Dunn, William, Public Policy Analysis, Fifth Edition, (Pearson Press, 2011) p.10.
} 
A system of government is created to provide for a different allocation of values than would otherwise exist. A democratic system takes in feedback from citizens and then translates that input into policy prescriptions for addressing whichever conditions the citizenry finds suboptimal or unacceptable. Ideally the political institutions of a democratic government work perfectly to translate voter preferences into valueoptimizing policy choices. But, just as the market system sometimes fails to be efficient, sometimes the policymaking bodies of representative government fail to validly and reliably embody the long-term preferences of the electorate.

Conceptually, this thesis approaches ballot initiatives as simultaneously responding to both market failures and government failures. Initiative passage/rejection occurs because of the reality or the perception that certain policymaking problems exist which representative political institutions are systemically ill-equipped to solving. Explaining initiative passage, on a conceptual level, compels researchers to examine the link between the nature of certain types of policy problems, and some feature of the current constellation of representative policymaking institutions.

Studies support the notion that the initiative process operates as an institutional alternative to groups that struggle to find influence in the legislature. A 1997 study by P.F. Heiser and M.E. Begay concluded that the critical factor behind the decisions of public health activists to launch an initiative was "the apparent influence of the tobacco industry upon the legislature." ${ }^{104}$ Gerber found in 1998 that groups who used the initiative process consistently identified among their primary motivations the failure of

\footnotetext{
${ }^{104}$ P.F. Heiser and M.E. Begay, "The Campaign to Raise the Tobacco Tax in Massachusetts." American Journal of Public Health, Vol. 87, No. 6, (June 1997) pgs. 968-973.
} 
the legislature to respond to their interest. Similarly, interviews with initiative sponsors have identified similar beliefs about legislative unresponsiveness among their motivations. $^{105}$

A causal narrative of passage demands assumptions about ballot qualification. Qualification is prerequisite for passage. Are the same factors that determine qualification the ones which determine passage? The literature on collective action problems examined earlier suggests that an interest's narrowness might benefit it more in the qualification stage and its breadth might benefit an initiative more in the passage phase.

In Anne Campbell 1997 dissertation, the author places the process into a policymaking process with many different stages and actors to consider. She focused on policy entrepreneurship and agenda-setting through the state ballot initiative process. Campbell built her study upon the insights of Roger Cobb and Charles Elder, who observed that organized interests competed for influence over public officials who possessed "considerable freedom to choose among the plethora of issues competing for attention." 106 Indeed, studies of the U.S. Congress concluded that legislators displayed significant control over their personal and legislative agendas. ${ }^{107}$ Campbell emphasized the conditions under which elected policymakers made their decisions. Via Campbell, policymaking emerges out of "the strategic concerns of politicians who seek to increase

\footnotetext{
105 Anne G. Campbell, Setting the Initiative Agenda: The Not-So-Silent Majority. Phd dissertation, University of Colorado Department of Political Science (Ann Arbor: UMI Company, 1998).

${ }^{106}$ Roger W. Cobb and Charles D. Elder, Participation in American Politics: The Dynamics of AgendaBuilding, (Boston: Allyn and Bacon, 1983) p. 20.

${ }^{107}$ Timothy E. Cook, Making Laws and Making News (Washington DC: The Brookings Institution, 1989); Barbara Sinclair, The Transformation of the U.S. Senate (Baltimore: John Hopkins University Press, 1989).
} 
their own visibility by promoting new issues on the agenda, but who stay away from issues that make lots of enemies."108

The data in Campbell's dissertation was gathered from the 26 statewide initiatives on Colorado ballots from 1996-1992. Of these 26 initiatives, data was only available for 24 of the contests. Interviews were conducted with either initiative sponsors (in 22 of the cases) or with key campaign workers (in the other 2 cases). Campbell identifies a central role for the initiative process in handling "hot potato" issues and conflicts of interest spilling over from the legislature. Campbell's dissertation tapped into some of the Approach \#3 literatures most compelling explanatory strengths, providing the deeper, policy process-embedded explanations of ballot initiative passage so lacking from the Approach \#1 literature. Analytically, Campbell searched for causal connections between initiative contest outcomes and the failure of both markets and governments.

The explanations found in the Approach \#3 literature provides a critical feature missing from other explanations, being informed by the context of the policy process and the political institutions that structure it. These explanations share a linkage between ballot initiative successes and the failures of both markets and representative institutions of government. Now that some the more theoretical elements of institutionally-embedded explanation have been introduced, the following subsection will examine explanations embedded in understandings of political parties and the party system.

\footnotetext{
108 John W. Kingdon, Agendas, Alternatives, and Public Policies (New York: Harper Collins Publishers, 1984); Edward Carmines and James Stimson, Issue Evolution: Race and the Transformation of American Politics (Princeton N.J.: Princeton University Press, 1989); Cook, Making Laws and Making News; Sinclair, The Transformation of the U.S.
} 


\section{Political parties and party systems}

What does academic research offer in regards to explanations of ballot initiative success which are informed by claims about political parties and the distribution of partisan attachments in the electorate? Is the ballot initiative process outside and independent of partisan politics in some substantive way? First, this subsection begins by providing some background on the nature of political parties and the dynamics of party systems.

James L. Sundquist's 1973 book on the Dynamics of the Party System provided an influential and parsimonious explanation of the way political competition is structured and managed in a two-party system. ${ }^{109}$ For Sundquist, parties enable political competition, and their configuration within a party system is determined by their ability to resist destructive and degenerative pressures generated by internal competition and issue proliferation. These are that pressures that tear party-coalitions apart.

Via Sundquist, a party's only hope of survival lies in its capacity to manage the changing requirements of assembling electoral majorities. Changing political conditions require parties to absorb internally-divisive new issues as they emerge. Sundquist analyzed recurrent patterns and critical junctures that he claimed structure the rise and fall of parties and party systems.

Sundquist defines a party system as the distribution of basic party loyalties and attachments. He began his theory of parties in the style of a deontological thought experiment, inviting readers to hypothesize about an "undifferentiated... classless,

\footnotetext{
${ }^{109}$ James L. Sundquist, Dynamics of the Party System, Revised Edition, (Washington DC: Brookings Institution Press, 1983
} 
partyless, ungrouped, atomized society." ${ }^{110}$ Suddenly a policymaking controversy emerges that splits the electorate in two. "The undifferentiated society suddenly differentiates." A single line of party cleavage is all that organizes the ideological space in which voters form their attachments.

Next in Sundquist's model, another issue comes along that divides the electorate along a separate, second dimension of party cleavage. These "cross-cutting, partysplitting issue[s]" are the undoing of party systems. Sundquist posits a set of requirements created by the logic of party survival and party system management. How do these requirements affect the process by which initiative contest outcomes are generated? Via Sundquist, competition between parties rests on building dependable electoral coalitions across a highly differentiated body of policy-demanders who decide elections in each state. The emergence of new issues leads to changes in the basis of political competition which can, in turn, cause changes in the electoral fortunes of either party. Parties benefit from an ability to absorb new, potentially disruptive lines of party cleavage before they lead to an electorally undesirable conflict displacement.

One major implication of Sundquist's logic is that electoral representatives have the opportunity and incentive to control the basis of political competition, and by extension the substance of policy disputes. This implies that the initiative process could be at time both helpful and harmful to the interests of parties themselves. If an initiative helps settle some internally divisive issue that threatened the party, the effect is positive. But if the initiative contest increases the salience of some cross-cutting issue, the effect is to divide the electorate in a way that is disadvantageous to the party's electoral fortunes.

\footnotetext{
${ }^{110}$ Sundquist, Dynamics of the Party System, p.19.
} 
In contrast to theories of political parties centered on the preferences and behaviors of election-minded politicians, a recent "group-centric" study of political parties recast policy-demanding interest groups and activists as the key actors. "Groups of organized policy demanders are the basic units of [the] theory of parties" put forth in the 2012 article by Kathleen Bawn, Martin Cohen, David Karol, Seth Masket, Hans Noel, and John Zaller. ${ }^{112}$ Bawn et al. make note of the normative implications, wherein their activist- and interest group-dominated, policy demander-oriented party theory is expected to be less responsive to voter preferences than a party controlled by election-driven politicians.

The nomination stage of candidate races is the primary arena where Bawn et al. point to illustrate the group-centric nature of parties and the implications for policymaking. "Nominations," Bawn et al. claim, "are a natural focus of interest groups and activists." 113 Controlling nominations is more effective than lobbying because it helps policy-demanders overcome principal-agent problems between themselves and incumbents. Moreover, the authors write that "the advantageous position of groups at the nomination stage is bolstered by lack of voter interest... The costs of providing selected politicians with what they need to win a primary election are often small."

In a break with an old paradigm of candidate-centered parties, Bawn et al. conceived of parties as the creatures of policy-demanding interest groups and activists. If one accepts this shift in our understanding of parties, the relationship then changes

\footnotetext{
${ }^{111}$ Kathleen Bawn, Martin Cohen, David Karol, Seth Masket, Hans Noel, and John Zaller, "A Theory of Political Parties: Groups, Policy Demands and Nominations in American Politics," Perspectives on Politics, Vol. 10, No.3, (2012) p.1.

${ }^{112}$ Ibid, p. 6.

${ }^{113}$ Ibid, p. 7.
} 
between political parties and ballot initiatives. If candidate-driven parties are often in an adversarial stance to initiative entrepreneurs, the group-centric conception of political parties implies a cozier, more complementary relationship between party and ballot initiative politics.

When the ballot initiative was introduced to the states at the beginning of the $20^{\text {th }}$ century, the Progressive and Populist reformers sought targets beyond the moneyed interests thought to hold undue sway over elected officials. Reformers also targeted the political parties and party bosses who controlled state governments. ${ }^{114}$ For the most part, American ballot initiative contests tend to be initiated and financed by groups falling beyond the reaches of parties. Research has examined how truly separate the lawmaking processes managed by parties actually are from the ballot-box lawmaking of the initiative process. Writing in 2001, Daniel A. Smith and Carline J. Tolbert argued that state and national parties were increasingly becoming involved in the initiative process.

Smith and Tolbert identified three main "motivating factors" for increasing party involvement in initiative contests. First, parties may become involved to promote turnout for the parties' own candidates. Second, parties may engage in initiative politics to drive issue wedges into an opposing party's electoral coalition. And thirdly, a party might take a role in initiative contests whose outcome engages them ideologically. ${ }^{115}$

\footnotetext{
${ }^{114}$ Thomas E. Cronin, Direct Democracy: The Politics of Iniiative, Referendum, and Recall, (Cambridge: Harvard University Press, 1989) pgs. 50-57.

${ }^{115}$ Daniel A. Smith and Caroline J. Tolbert, "The Initiative to Party: Partisanship and Ballot Initiatives in California," Party Politics, Vol. 7, No. 6, (2001) p. 741.
} 
Tolbert and Smith claimed that "it is becoming evident that initiatives are not 'beyond party politics"” as other scholars claimed. ${ }^{116}$ The authors' research design employs both aggregate data of counties and survey data of individuals. The aggregate data measures the impact of party on county-level voting for California initiatives. County-level voting patterns were analyzed "for the 13 statewide ballot initiatives appearing on the June 1998 primary and November 1998 general election ballots in California." 117 Their design measured whether support for the ballot initiatives was related to a county's party composition, as measure in percentage of registered Republicans. This aggregate analysis controls for two competing explanations for policy adoption: prevailing economic conditions and racial/ethnic diversity. ${ }^{118}$

Smith and Tolbert's survey data are used to measure the importance of political party affiliation to a series of initiative and candidate votes in the 1994 and 1996 California general election. Data came from Voter News Service Exit Poll of California voters. Separate logistic regression models are used to model voter support for several ballot initiatives. Additionally, by analyzing voting in two consecutive elections, the authors provide evidence of the impact of party affiliation over time.

The aggregate, county-level analysis showed that party affiliation was associated with the vote for 77 percent of the initiatives appearing on the 1998 California ballots, even when controlling for the competing explanations. This was a positive and statistically significant relationship. Additionally, the survey data of individual voters

\footnotetext{
116 Ibid, p. 744.

117 Ibid, p. 746.

118 Shaun Bowler and Todd Donovan, "Economic Conditions and Voting on Ballot Propositions," American Politics Quarterly, Vol 22, No.1 (January 1994); Rodney Hero, Faces of Inequality: Social Diversity in American Politics (Oxford University Press, 2000).
} 
provided further evidence of the ways parties had become entangled in initiative politics. In their analysis of the surveys, Smith and Tolbert conclude that the single most salient predictor of voting behavior in initiative contests was party affiliation.

Earlier in the Approach \#2 section of this literature review, Elizabeth Gerber's 1999 book on ballot initiative politics was examined. ${ }^{119}$ Gerber's work has footing in both Approaches \#2 and \#3. While focusing on the distribution of costs-and-benefits that an initiative engages, Gerber's analysis always remains footed in the relevant institutional realities. Via Gerber, broad-based groups promoting “citizens interests" enjoy a comparative advantage in the initiative arena. On the other hand, concentrated "economic interests" are generally better positioned to benefit from legislative logrolling to enjoy targeted benefits through compromise, as well as being equipped to use the vetogates in the legislature to block proposals they oppose. ${ }^{120}$

Gerber's initiative process is not the site of interest groups circumventing legislatures. Instead, Gerber's initiative process is a site where broad groups can keep narrow groups in check. A concentrated interest would prefer to lobby for policy changes that gain fast traction with elected officials and remain noncontroversial within the electorate. The initiative process is a site where voters can overcome the inherent limitations that they face as they attempt to express their preferences on a broad and multidimensional range of issues through a single vote.

\footnotetext{
${ }^{119}$ Gerber, The Populist Paradox.

${ }^{120}$ Elisabeth Gerber, "Direct Democracy," in Elgar Handbook on Public Law and Public Choice, eds. D.A. Farber and A.J. O'Connell (Massachusetts: Edward Publishing Group, 2010).
} 
In a paper from 2000 by Timothy Besley and Stephen Coate, the authors examined the potential for "Issue Unbundling via Citizens' Initiatives." ${ }^{121}$ In an analysis informed by public choice theory, the authors argue that, in a representative democracy, "the bundling of issues together with the fact that citizens only have one vote, means that policy outcomes on specific issues may diverge far from what the majority of citizens wants." When this occurs, the viability of the initiative process "permits the unbundling of these issues, which forces a closer relationship between policy outcomes and popular preferences."

The normative question of whether or not issue unbundling is socially desirable is packed with Madisonian implications. Does the initiative process blast through ideological gridlock, or thwart compromises that should be left to elected representatives. Besley and Coate's analysis does not attempt to answer these normative questions, but does provide evidence that the initiative process allows for the unbundling of issues, permitting citizens to evaluate candidates on a more refined set of issues than is available in its absence. In the sample observed by Besley and Coate, the initiative process helped remove some elements of fiscal policymaking from the domain of elected politics.

Most importantly, what are the consequences of "issue unbundling" for political parties and the balance of the party system?

\footnotetext{
${ }^{121}$ Timothy Besley and Stephen Coate, "Issue Unbundling via Citizens' Initiatives," Quarterly Journal of Political Science, Vol. 3, No. 4 (December 2008).

122 Ibid, p. 379.
} 


\section{Success beyond passage}

The explanations of initiative contest outcomes that have been examined up until this point in the Literature Review have all defined ballot initiative success/failure in terms of passage/defeat. A lot of explanatory value has been derived from assuming that policy-demanding individuals and groups contest ballot initiative outcomes in terms of passage/rejection. However, this final subsection will demonstrate the explanatory implications of the possibility that policy-demanders engage in initiative contests in pursuit of goals besides direct passage or rejection of initiatives.

Do policy-demanding individuals and groups define their objectives (success) in dimensions beyond passage/defeat? How does an expanded definition of success affect the explanation of passage? From the policy analysis literature, Alan McConnell wrote a 2010 article which put forth a multi-dimensional frame for understanding policy success and failures. Via McConnell, policy success/failure exists along three dimensions: processes, programs, and politics. McConnell drew distinctions between different forms and degrees of policy success and failure. McConnell identifies tensions between different forms of success "including what is known colloquially as good politics but bad policy."123

Process is McConnell's first dimension of policy success. Process success preserves government policy goals and instruments. Program success evaluates the "basic resources and tools of government." ${ }^{124}$ Lastly, political success is determined by how

\footnotetext{
${ }^{123}$ Allan McConnell, "Policy Success, Policy Failure and Grey Areas In-Between.” Journal of Public Policy, Vol. 30, No. 3, (2010) p. 346.

${ }^{124}$ Ibid, p. 350.
} 
favorably policymakers can manage their electoral prospects and enhance their reputations.

McConnell's analytic frame could easily and fruitfully be transferred to the context of initiative process policymaking. In relation to McConnell's 3 "realms" of policy success/failure, the initiative arena's version of process success is the mobilization of groups and the establishment and maintenance of issue network infrastructure which helps to "build sustainable coalitions." ${ }^{125}$ Program success relates to the passage/defeat dimension of contest outcomes that is the main focus of this thesis.

Political success is a realm that often overlaps with the other two. In initiative contest outcomes, political success relates to how officeholders and partisan interests are affected by the initiative process. The political dimension of initiative contests concerns whether outcomes change the basic structure of political competition or enhances the prospects of particular parties and candidates.

It seems probable that, if these nonpassage dimensions are significant, then explaining passage might require understanding them and their properties. Explaining the behavior of policy-demanders in the initiative arena will be distorted if one operates under the assumption that passage is the exclusive goal of actors.

A large number of gay marriage bans passed through statewide initiatives in the early $21^{\text {st }}$ century. The gay marriage ban initiatives achieved near universal program success, but about a decade down the road, these initiative efforts appear to have resulted in process and political failures for their proponents. While racking up program victories

${ }^{125}$ Ibid, p. 352. 
they allowed latent interests to become activated. Media attention focused on the initiative contests in a way that changed voter sentiment as well.

Or, conversely, take the many tax revolt initiative campaigns in the wake of California's Proposition 13 (1978). Most of them failed, but their program failures are forgotten while their effects on California's politics and political process persist to this day. A conclusion of this literature review is that explanations of formal passage and rejection can only tell part of the story of initiative politics. Yet on the other hand, the thesis holds that majority-dependent passage is the central organizing feature of ballot initiative politics.

The initiative sponsor interviews conducted for Campbell's 1997 dissertation speak to the question of how nonpassage objectives fit into the strategic behavior initiative actors. Campbell's findings indicated that passage was the primary goal of Yes actors. In all but 2 of the 24 initiative campaigns whose sponsors or key staff were interviewed, the respondents "indicated that at the outset of the campaign they believed that their initiatives would be approved by the public." ${ }^{126}$ Campbell quoted one sponsor as responding, "Sure, why else do it?" The policy entrepreneurs who pulled the trigger on initiative contests overwhelmingly identified passage as the primary objective of their efforts.

Nonpassage objectives of initiative actors merit consideration, but it must be kept in mind that the perceived likelihood of passage manages the decision-making of all actors throughout the initiative process. Passage potential is apparently a decisive threshold for the decision-making of initiatives which land qualification. However,

\footnotetext{
${ }^{126}$ Campbell, Setting the Initiative Agenda, p. 249.
} 
research needs to be expanded to unpack the dynamics of the initiative qualification process. What kinds of initiative projects get attempted and fail to qualify for ballot access? What characteristics distinguish successful qualification efforts from failures? These questions may prove to be even more revealing in explaining initiative contest outcomes than explaining processes that occurs further along in the sequences of events that starts with the petition and ends at the ballot box. 


\section{- Chapter 2 -}

Methods

The Methods chapter of this thesis paper is structured in the same manner as the review of the literature. Three designs will speak to the three approaches to explaining initiative contest outcomes. Design \#1 will mirror Approach \#1 by examining campaign expenditures in initiative contests. Design \#2 will speak to Approach \#2 by applying the Wilson typology of cost-benefit distribution to a sample of California and Oregon initiatives. Finally, Approach \#3 comes through in Design \#3, which examines how party affiliation corresponds to county-level voting patterns on a number of recent Oregon initiative contests.

\section{Design \#1: Picking losers? The strategic financing of initiative campaigns}

The Literature Review's section on Approach \#1 detailed studies which examined the explanatory properties of campaign spending in relation to initiative contest outcomes. Prominent in the analysis were recent studies which claim that the endogenous relationship between campaign resources and passage potential has distorted past estimations of the effectiveness of those resources when they are manifested in the form of campaigns spending. Authors find inspiration in congressional literature that demonstrates how contributions in candidate races go to "picking winners." Thomas 
Stratmann wrote in 2005 wrote, "One of the most robust findings in the literature is that

money flows to incumbents in close races." ${ }^{, 127}$

Donors may simply be heaping funds on those who will win anyway, perhaps because they wish to influence the members once in office. We posit that campaign spending, especially money that goes to support initiatives, is also endogenous to their electoral chances but in just the opposite way. Money may flow to initiatives that are in danger of failing. Since contributors cannot hope to buy influence over the unchanging language of a ballot measure, there is no reason to pile money on one that is already headed for passage. Yet if an initiative looks vulnerable, its supporters - especially those who have already invested substantial sums to qualify it for the ballot - may contribute large amounts to campaign for its survival. If this story is correct, consider its implications for the conventional econometric approach. ${ }^{128}$

This design will interrogate whether campaign spending in initiative contests appears to be targeted toward the most competitive races. Are initiative campaign financers systemically picking losers as recent literature claims?

\section{Data}

The data for the analysis under Design \#1 came from three western states:

California, Oregon, and Washington. A total of 49 general election initiative contests are examined which took place between 2012 and 2004. This author conducted an exhaustive search for all reasonably rigorous opinion polls conducted in advance of initiative contests. Regrettably, opinion polling was not available for all initiative contests within

\footnotetext{
${ }^{127}$ James Kau, Donald Keenan, and Paul Rubin. "A General Equilibrium Model of Congressional Voting," The Quarterly Journal of Economics, Vol. 2, (1982); Gary Jacobson, "Money and Votes Reconsidered: Congressional Elections 1972-1982," Public Choice, Vol. 47 (1985); Keith T. Poole Thomas Romer, "Patterns of Political Action Committee Contributions to the 1980 Campaigns for the U.S. House of Representatives," Public Choice, Vol. 37 (1985); Thomas Stratmann, "Are Contributors Rational? Untangling Strategies of Political Action Committees," Journal of Political Economy, Vol. 100, No. 3, (July 1992).

${ }^{128}$ de Figueiredo et al., Financing Direct Democracy, pgs. 9-10.
} 
the time period. Moreover, opinion polling data was by far the most robust for California contests. A total of 205 opinion polls were collects for the 49 contests. This makes for an average of 4.2 opinion polls per initiative contest.

The polls were collected from newspapers, think tanks, universities, interest groups, and private polling firms. ${ }^{129}$ The sample sizes vary based upon the techniques, setting, and resources of the surveyor. Polls were only included which indicated Yes vote percentage in terms of the stated intentions of "likely voters" who were given an option to indicate "undecided" or "no opinion."

A five-point scale, shown below in Figure 3.1.1, represents the competitiveness of initiative contests as registered in opinion polling.

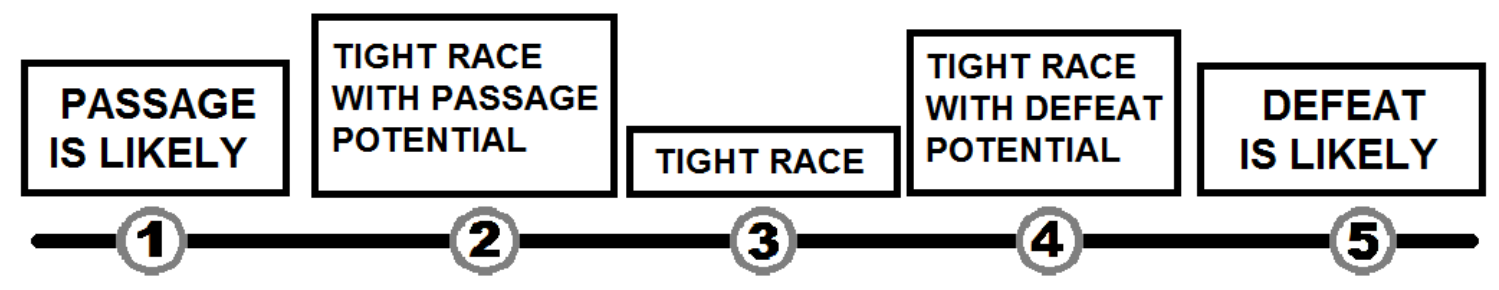

FIGURE 3.1.1: 5-point competitive dynamic scale for initiative contests

\footnotetext{
${ }^{129}$ California Business Roundtable website, "Studies and Resources," California Business Roundtable and Pepperdine University School of Public Policy; Elway Research website, "The Elway Poll," Elway Research, Inc.; Field Poll website, "Poll Archive," Field Poll; Ipsos website, "Reuters Polls," Ipsos/Reuters Poll; PPIC website, "Statewide Surveys," Public Policy Institute of California; PPP website, "Polls," Public Policy Polling; Reason-Rupe website, "Reason-Rupe Data Archive," Reason-Rupe; Survey USA website, "Election Polls," Survey USA; USC Dornsife website, "PACE/USC Rossier School of Education Poll," University of California Dornsife Rossier School of Education; USC Dornsife website, "USC Dornsife/Los Angeles Times Poll," University of California Dornsife and Los Angeles Times; Washington Poll website, "Poll Archives," The Washington Poll.
} 
Type 3 polls indicate the most competitive races. If a poll's "Yes minus $N o$ " differential is not within the margin of error, then it is within a striking distance where the difference likely appears to be changeable with marginal campaign expenditures. Strategically speaking, Type 3 polls should indicate a situation where Yes actors have especial incentive to spend. However, the same holds true for $N o$ actors who find themselves competing in Type 3 contests.

Type 1 polls indicate that passage is very likely for a given initiative. The assumption of many recent studies is that Type 1 polls represent a situation where Yes actors have a strong disincentive to expend resources. Type 2 polls, falling between Types 2 polls represent situations in which passage is deemed more likely than in Type 3 but less likely than in Type 1.Type 4 polls are still somewhat competitive, but the initiative's odds of passage are trending slightly downwards. Type 5 polls indicate an initiative is very likely to be defeated. Classification of polls by type was performed using the following procedure:

- STEP 1: The first cut of classification involved automatically including in Type 1 all polls which registered $50 \%$ or more of respondents as indicating an intention to vote Yes.

- STEP 2: Any poll where 50\% or more of voters intend to vote No is typed as a 5 .

- STEP 3: Any poll where the "Yes minus No" differential is greater than -10 and less than 10 is grouped into Type 3 (tight races). This rule supersedes Steps 1 and 2 , though in practices it was extremely rare for a poll to indicate over 50 percent for either sider without also cranking out a "Yes minus No" differential outside of Step 3's purviews.

- STEP 4: All polls with a "Yes minus No" differential between 15 and 10 are classified as Type 2 .

- STEP 4: All polls with a "Yes minus No" differential -15 and -10 are classified as Type 4.

Once each opinion poll had been individually typed, each initiative was grouped with its respective polling type measurements and assigned a Median Polling Type. In the 
rare instance (once) when necessary, decisions were made between irregular even numbered steps which served an assumption that races were more, rather than less competitive. This assumption came from the deduction that the lack of an emergent mode indicates some manifestation of contestation within the situation.

\section{Analysis}

Descriptive statistics and graphing are employed in the Findings chapter to illustrate the distribution of polling by type, both in terms of total polling and median polling types. To test the effectiveness of median polling types as an indicator of an initiative contest's demonstrable probability of occurring, data was collected on the outcome of every contest both in terms of vote share and passage/defeat.

Descriptive statistics and correlational techniques will illustrate the strength of median polling type as a demonstrable indicator of an initiative's likelihood of passage, available to all engaged citizens and policy-demanders in the run-up to each election. This will speak to the validity of Median Polling Type as a demonstrable measure of the competitive dynamic of a race. Data on initiative voting was collected from the Secretaries of State's offices for California, Oregon, and Washington. ${ }^{130}$

At this point campaign finance report data on campaign expenditures is folded into the analysis. Data was, once again, collected from the respective Secretary of State's

\footnotetext{
${ }^{130}$ California Secretary of State website, "Statewide Elections: 2012-1990," California Secretary of State; Oregon Secretary of State website, "Election History Archive," Oregon Secretary of State; Washington State Secretary of State website, "Elections \& Voting: Research \& Past Results," Washington State Secretary of State.
} 
offices for California, Oregon, and Washington. ${ }^{131}$ Campaign spending was measured as all reported campaign expenditures by committees registered to advocate in initiative contests.

Expenditures were only counted which occurred in the same year as the election. This was done to avoid underestimating the influence of marginal Yes spending by excluding many of the fixed costs of getting initiative's qualified. It also allows for policy-demanding individuals and groups to learn about the dynamics of contests and the potential costs or benefits of different outcomes. When possible, in-kind contributions were included along with hard expenditures.

Measurements of campaign "spending strength" were also constructed to permit for cross-state analysis. A spending strength score for a Yes campaign from California is the mean Yes spending for all California campaigns divided by the mean spending for that specific Yes or No spending effort.

Example:

- California (2008) Proposition 8 Yes campaign expenditures equaled $\$ 41,707,000$.

- $\quad$ Then, California mean Yes campaign spending equaled $\$ 16,355,000$.

- $\quad$ So, divide California (2008) Prop. 8 Yes spending ( $\$ 41.7$ million) by the mean Yes spending ( $\$ 16.35$ million) and this creates the "spending strength" of Prop. 8 Yes campaigns (2.55).

The following are hypotheses for Design \#2.

- Hypothesis \#1.1: Mean Yes spending strength will be lowest in the situations which lean towards passage, and highest in the situations which lean towards failure.

- Hypothesis \#1.2: Mean No spending strength will be highest in the situations that are the most competitive.

\footnotetext{
${ }^{131}$ California Secretary of State website, "Cal-Access Database," California Secretary of State; Oregon Secretary of State website, "ORESTAR Database," Oregon Secretary of State; Washington State Public Disclosure Commission website, "Search the Database," Washington State Public Disclosure Commission.
} 


\section{Design \#2: Wilson typing and initiative contest outcomes}

The typology employed in this design sorts initiative contests based on the substance of the policy at stake in each contest, whether the costs and benefits of proposed initiatives were concentrated narrowly within certain groups or diffused broadly across society. The typology is repurposed from James Q. Wilson's The Politics of Regulation. ${ }^{132}$

In explaining the political origins of regulatory policies and administrative agencies, Wilson created and employed the typology that now promises to help organize the world of ballot initiatives. Wilson wrote:

Elsewhere I have suggested that policy proposals, especially those involving economic stakes, can be classified in terms of the perceived distribution of costs and benefits. These costs and benefits can be monetary and nonmonetary, and the value assigned to them, as well as beliefs about the likelihood of their materializing, can change... The political significance of these costs and benefits arises out of their distribution as well as their magnitude... [, they] may be widely distributed or narrowly concentrated. ${ }^{133}$

Wilson's typology is illustrated below in Figure 3.2.1.

\footnotetext{
${ }^{132}$ Wilson, The Politics of Regulation.

${ }^{133}$ Ibid., 366-367.
} 


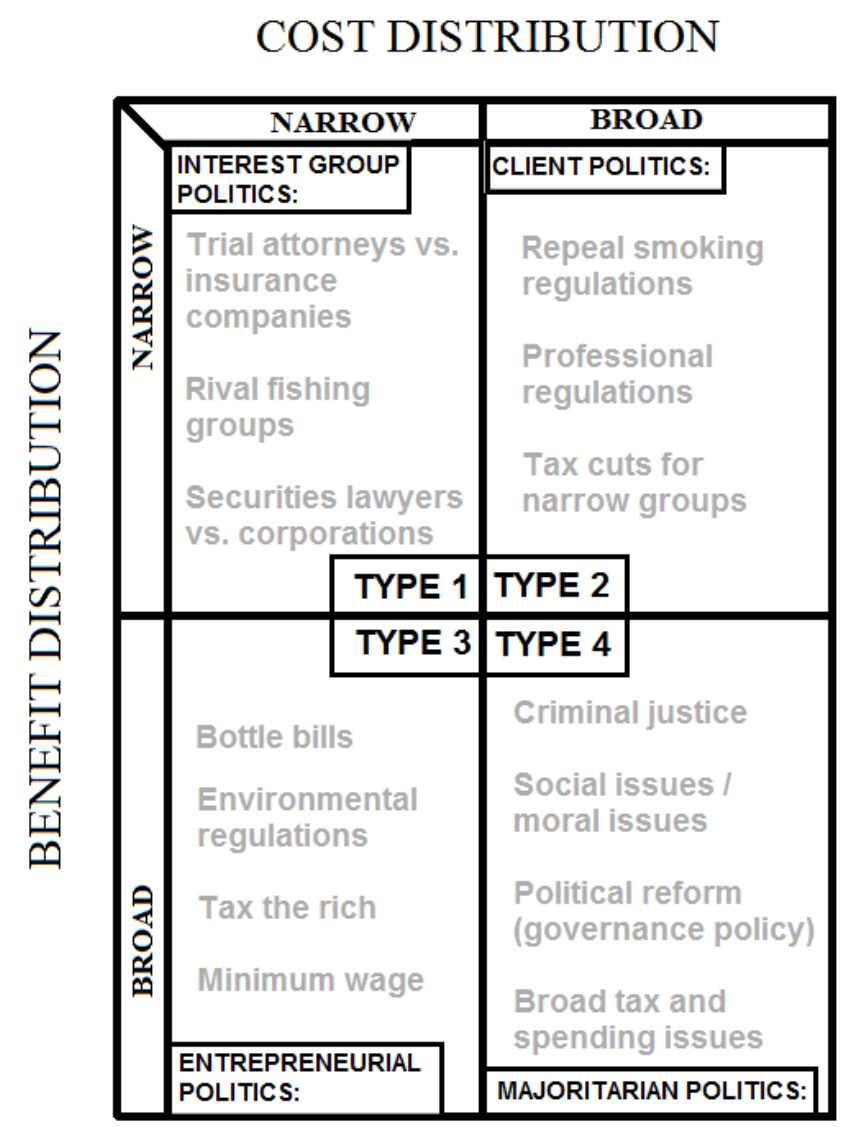

FIGURE 3.2.1: "A Simple Classificiation of Initiative Contests" using the Wilson typology ${ }^{134}$

Interest-group politics refers to a situation where the perceived costs and benefits of a policy are narrowly distributed. Often this involves two competing interest groups contesting a regulation. When costs and benefits are broadly distributed, this situation is referred to as majoritarian politics. Majoritarian politics involve situations where "all or most of society expect to gain" and "all or most of society expects to pay." 135 Narrowness of costs and benefits helps groups

\footnotetext{
${ }^{134}$ Donovan et al., Contending Players and Strategies, p.84.

${ }^{135}$ Ibid, 367.
} 
overcome collective action problems. For this reason, one generally expects to find better organization and funding for narrow causes than for broad ones.

When benefits are narrow and costs are widely distributed, Wilson calls this a situation of client politics. ${ }^{136}$ A small group expects a big benefit and therefore has a strong incentive to organize and act in order to bring the policy about. The costs are spread so thin across the population that the broad masses have little incentive to oppose in an organized way. Finally, when a policy promises general benefits at the expense of a small segment of the population, Wilson labels this a situation of entrepreneurial politics. An energetic entrepreneur can mobilize a general interest against a narrow one and thereby overcome the public's collective action problem. Wilson characterizes the entrepreneur as "mobilizing latent public sentiment" and "associat[ing] the legislation with widely shared public values."137

\section{Content analysis}

How can narrowness and broadness be defined? Wilson's typology is

interested in the cost-benefit distribution in terms of "political significance."138 Political significance is defined through the "perceived distribution [and magnitude] of costs and benefits... and the value assigned to them." In situations where the stakes are nakedly financial, the distinction can be made in a fairly straightforward way. When the policies impose direct financial costs on one

\footnotetext{
${ }^{136}$ Ibid., 369.

${ }^{137}$ Ibid., 370.

${ }^{138}$ Ibid., 366-367.
} 
group, the quantification comes baked into the policy proposal. The narrow-broad distinction is easiest to make in these situations that give us a quantitative headstart. "X\% tax on a tobacco company," or " $\$ \mathrm{X}$ billion used to fund stem cell research," or "new X\% tax on anyone making X amount of income" - all are predisposed for this sort of sorting scheme.

However when we turn to contests about marijuana policy, abortion rights, eminent domain, and gay rights, it becomes much more ambiguous and arbitrary to classify initiative contests in this manner. Then, more to the point, even in those cases which at first appeared easy to quantify, their social, nonmaterial dimensions emerge upon closer analysis and confound attempts at simple classification.

So how could one go about measuring the narrowness or broadness of interests in contests which engage nonmonetary value conflicts? One method might be to examine the individual contributions. If an initiative campaign has a small number of large contributors, it would suggest a group motivated to gain a narrow benefit or avoid a narrow cost. Conversely, if an initiative campaign has a large number of people contributing small sums, it could be indicative of a group motivated to gain a broadly distributed benefit or avoid a broadly distributed loss.

The Wilson type coding that follows incorporates campaign contribution data to supplement the content analysis with data on the concentration or diffusion of contributions. In this way, the design of the typing reverses backwards from contribution data as an indicator of felt stake in an outcome. 


\section{Data}

Data was collected from 91 initiative contests between 2000 and 2012 in California, Oregon, and Washington. Using analysis of contribution data, ballot language, newspaper archives, and official voter information pamphlets, this author coded the initiatives into their respective Wilson types based on the distribution of costs and benefits that was understood to be at stake at the time of an initiative contest. Contests found difficult to code were collected and then coded independently by several other graduate students. This multiple coder design for the thornier classification problems was done to build intercoder reliability into the research design. ${ }^{139}$

Borrowing from the coding scheme of Anne Campbell, classification considers initiative impacts in terms of "economic, political, and/or social costs and benefits." First, analysis is conducted upon how different Wilson types are distributed within the sample. Which types are most and least prevalent? Then, the results will show the distribution of passage rates within this Wilson-typed sample. ${ }^{141}$ In a similar configuration, the mean Yes vote for the Wilson-typed sample will be calculated. ${ }^{142}$ In Design \#1, spending strength scores were calculated for Yes and No campaigns to enable cross-state analysis. At this point, Design \#2 deploys the same technique. Mean spending strength for both Yes and No campaigns is calculated using the Wilson-typed sample. The distributions will be presented in quadrant form.

\footnotetext{
${ }^{139}$ This technique mimics David McCuan's in “Can't Buy Me Love," pgs. 52-58.

${ }^{140}$ Campbell, "The Citizen's Initiative and Entrepreneurial Politics," p.8.

${ }^{141}$ California Secretary of State website, "Statewide Elections: 2012-1990," California Secretary of State; Oregon Secretary of State website, "Election History Archive," Oregon Secretary of State.

142 Ibid.
} 
The following are hypotheses for Design \#2.

- Hypothesis \#2.1: Spending strength of both Yes and No campaigns will be lowest in Majoritarian Politics situations and highest in Interest Group politics situations.

- Hypothesis \#2.2: Spending strength will higher in situations which serve narrow interests (Interest Group and Client Politics).

- Hypothesis \#2.3: Spending strength will be lower in situations which serve broad interests (Entrepreneurial and Majoritarian Politics).

- Hypothesis \#2.4: Passage rates will be highest in Majoritarian Politics situations and lowest in Interest Group politics situations.

- Hypothesis \#2.5: Passage rates will lower in situations which serve narrow interests (Interest Group and Client Politics).

- Hypothesis \#2.6: Passage rates will be higher in situations which serve broad interests (Entrepreneurial and Majoritarian Politics).

\section{Design \#3: Behind party lines?}

Design \#3 looks at initiative voting in the context of the system of party attachments within the electorate. Design \#3 is constructed to align with Approach \#3's emphasis on institutionally-embedded understandings of imitative contests and their outcomes. Do, as early advocates hoped, ballot initiatives function as a mechanism to carve out a policymaking arena outside of party control? How insulated is the initiative process from the influence of party-organized institutions that coexist alongside it.

Design \#3 examines how initiative politics and voting sometimes do and sometimes do not occur along party-based lines. Data was collected on 14 Oregon initiative contests between 2006 and 2000. Data was collected on the county-level, with the Yes vote percentage of each county collected for each initiative contest.

A measure of county-level attachment towards the Democratic party was created using the percentage vote for Democratic presidential candidate John Kerry in the 2004 presidential election. Correlational coefficients were calculated for each contest between 
county-level Yes voting and county-level Democratic attachment. Analysis is then performed that links the content of initiatives to the respective correlation between Yes voting and Democratic affiliation. Because of the two-party nature of American politics, the Republican Party affiliation score can largely be inferred to be the inverse of the Democratic affiliation value.

The following are hypotheses for Design \#3.

- Hypothesis \#3.1: Correlation between a county-level Yes voting and county-level party attachment will range between very high and moderately less high.

- Hypothesis \#3.2: In some observations, voting on initiatives will be strongly, positively correlated to county party affiliation, but in other observations it will be strongly, negatively associated

Associations between county-level initiative voting and party attachment will be measured in terms of a Pearson product-moment coefficient between county-level Yes voting and county-level Democratic Party affiliation. Hypothesis \#3.1 will require examination of the distribution of correlations by absolute value within the 14-contest universe of the sample. 


\section{- Chapter 4 - \\ Findings}

This chapter contains the findings of the data analyses projects laid out in the previous chapter, Methods. The subsections will correspond to the three approaches to explaining passage that have structured this research paper so far.

\section{Design \#1: Picking losers? The strategic financing of initiative campaigns}

The findings for Design \#1 begin with the distribution of polling types that emerged from a universe of 205 opinion polls conducted in California, Oregon, and Washington between 2012 and 2004. Classification procedures for poll typing can be found in the previous chapter. Figures 4.1.1 illustrates the distribution of polls in the sample as they correspond to the 5-point competitiveness typology

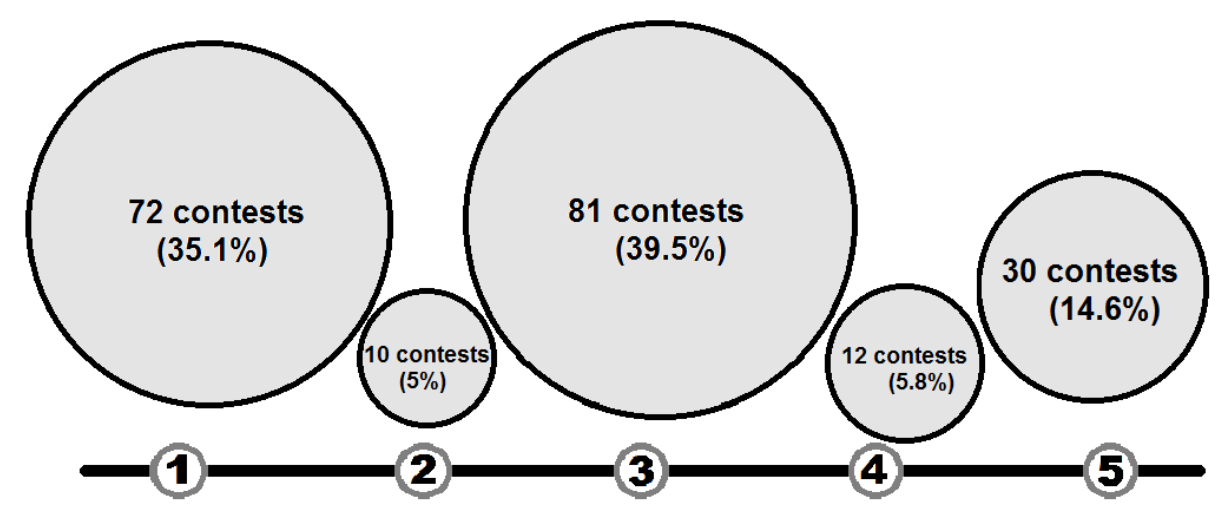

FIGURE 4.1.1: Distribution of initiative opinion polls by type

The distribution is double-peaked with the most occurrences of polls typed as $1 \mathrm{~s}$ and 3s. The most frequent poll type, Type 3, indicated the most competitive contests. The 
second most frequent poll type, Type 1, indicated the most Yes-advantaged situations. Polls in the sample of 205 were highly likely to indicate either tight races or heavy Yes advantages.

In order to examine the 5-point competitiveness typology a bit further, the categories are condensed in figure 4.1.2. Poll types 1 and 2 were collapsed into one another to form the LEANS PASSAGE category. Accordingly, categories 4 and 5 are collapsed into one another to form the LEANS DEFEAT category.

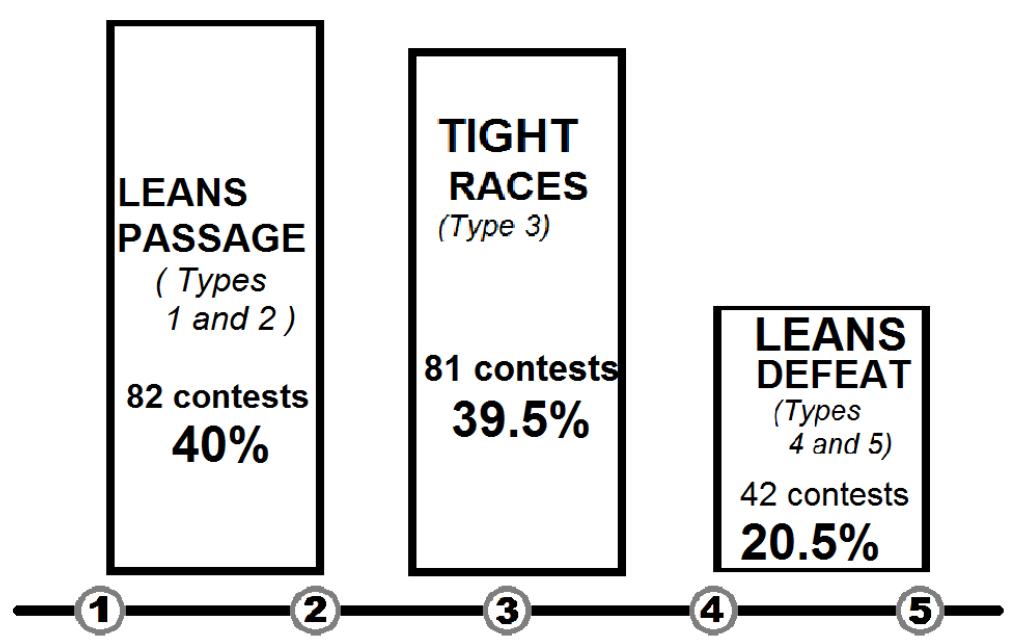

FIGURE 4.1.2: Distribution of polls by condensed competitive typing

The new categories even the data out, clarifying some of the trends first made visible in Figure 4.1.1. LEANS PASSAGE and TIGHT RACE poll were each twice as frequent as LEANS DEFEAT polls. These condensed categories will be deployed throughout the analysis as an alternative way of looking at the 5-point competitiveness system. 
The next step involved creating a Median Poll Type specific to each initiative contest. The Median Poll Type was intended to capture demonstrable evidence of how competitive contests were and in what direction the odds appear to be stacked in during the year of the election. The distribution of Median Poll Type among the contests is depicted in Figure 4.1.3.

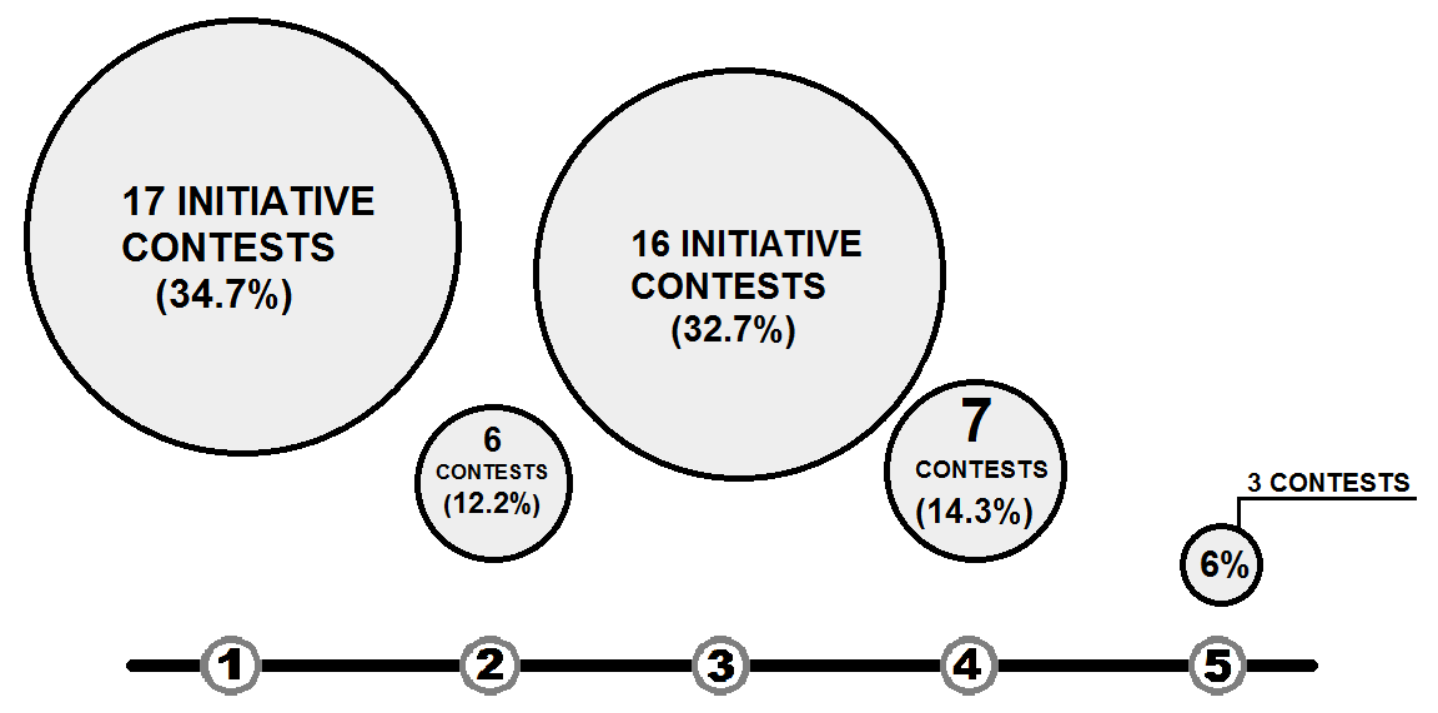

FIGURE 4.1.3: Distribution of competitive dynamic types within a sample of initiative contests 


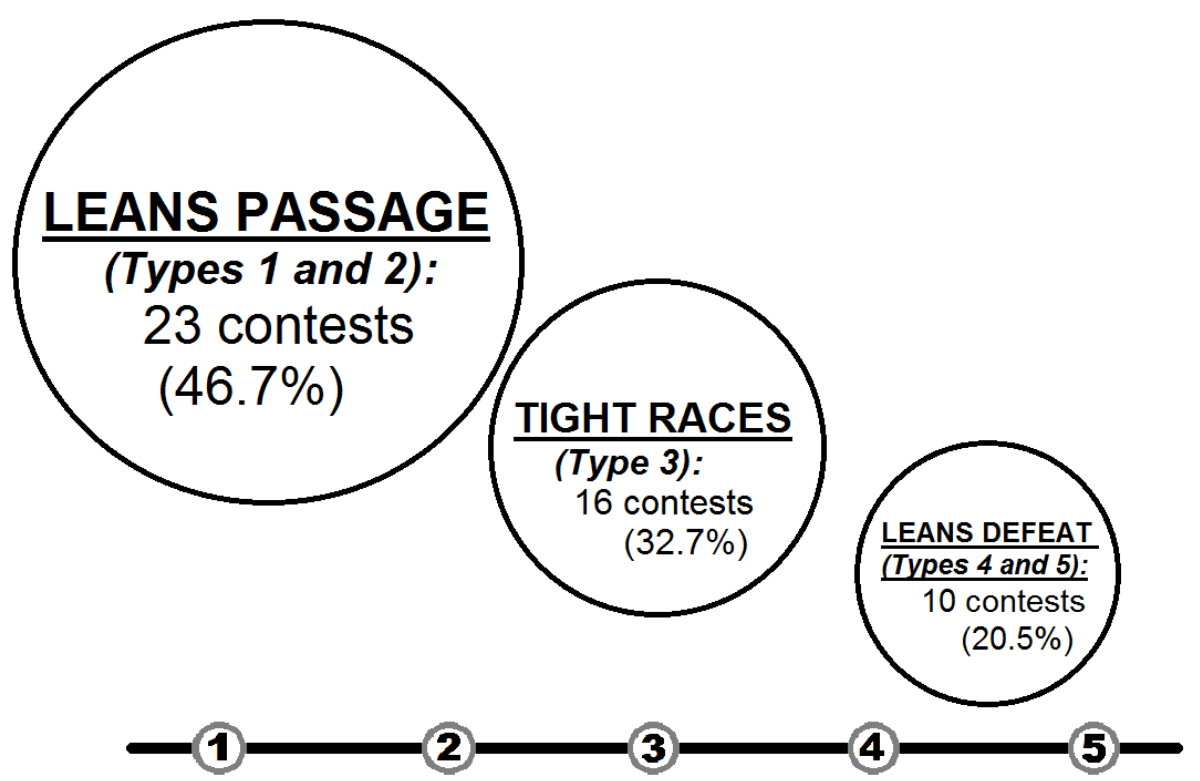

FIGURE 4.1.4: Distribution of occurrences of initiative contests within the condensed competitive dynamic categories

At this stage, data is integrated into the findings which relates to passage and the vote share of initiative outcomes. Obviously, vote share ultimately decides the passage or defeat of initiatives. Vote share and passage are the dependent variables which are necessarily engaged when explaining initiative contest outcomes. Data on mean vote share and passage percentage are displayed for each initiative type. Table 2 illustrates how success was distributed among contests within the 5-type universe. This part of the analysis speaks to the effectiveness of polling data and classification procedures for predicting initiative outcomes. 


\begin{tabular}{|c|c|}
\hline MEDIAN POLL TYPE & MEAN YES VOTE \% \\
\hline 1 & 56.4 \\
\hline 2 & 46 \\
\hline 3 & 43.7 \\
\hline 4 & 43.8 \\
\hline 5 & 29.8 \\
\hline
\end{tabular}

TABLE 2: Mean Yes vote percentage, by contest type

Mean Yes voting was distinctly higher (56\%) in Type 1 contests. The numbers steadily decline. By Type 5 contests, those indicating the lowest probability of passage, mean Yes voting has declined to $29.8 \%$.
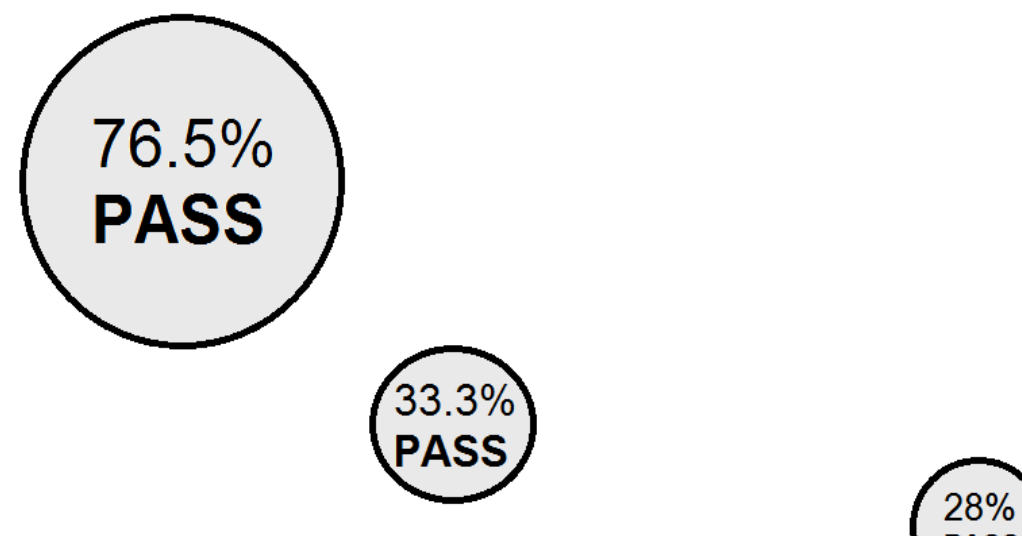

6\%)

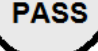

ZERO

PASSAGES

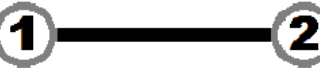

(3)
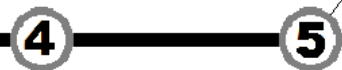

FIGURE 4.1.5: Passage rate distribution across contest types

Strikingly, 76.5 percent of all Type 1 initiative contests resulted in passage. Type 1

contests were over twice as likely to end in passage as the average contest in the data set.

Overall, this data shows that if an initiative contest was in Types 2-5, it was unlikely to 
pass on average. However, the probability was high that a Type 1 initiative contest would end in passage.

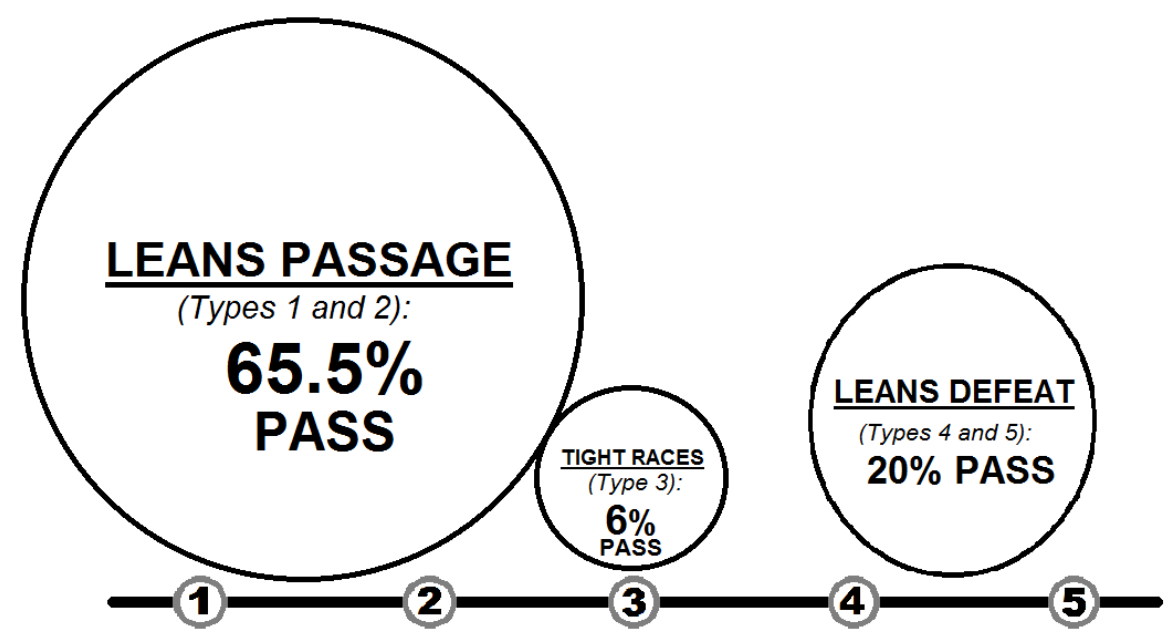

FIGURE 4.1.6: Distribution of passage rates across condensed categories of competitive dynamic

Passage rates are also revealing for the condensed categories. These are displayed above in Figure 4.1.6. The passage rate for passage-leaning contests was over three times higher than any other condensed category, suggesting the stability of polls as an indicator if a contest's outcome competitiveness.

Measures of campaign "spending strength" were constructed which held the level of spending constant to the size of the state in which it occurred. This was done in order to facilitate cross-state analysis of spending. In Figure 4.1.7, these "spending strength" measures are deployed in a comparison of mean Yes spending strength across the 3 condensed categories. 


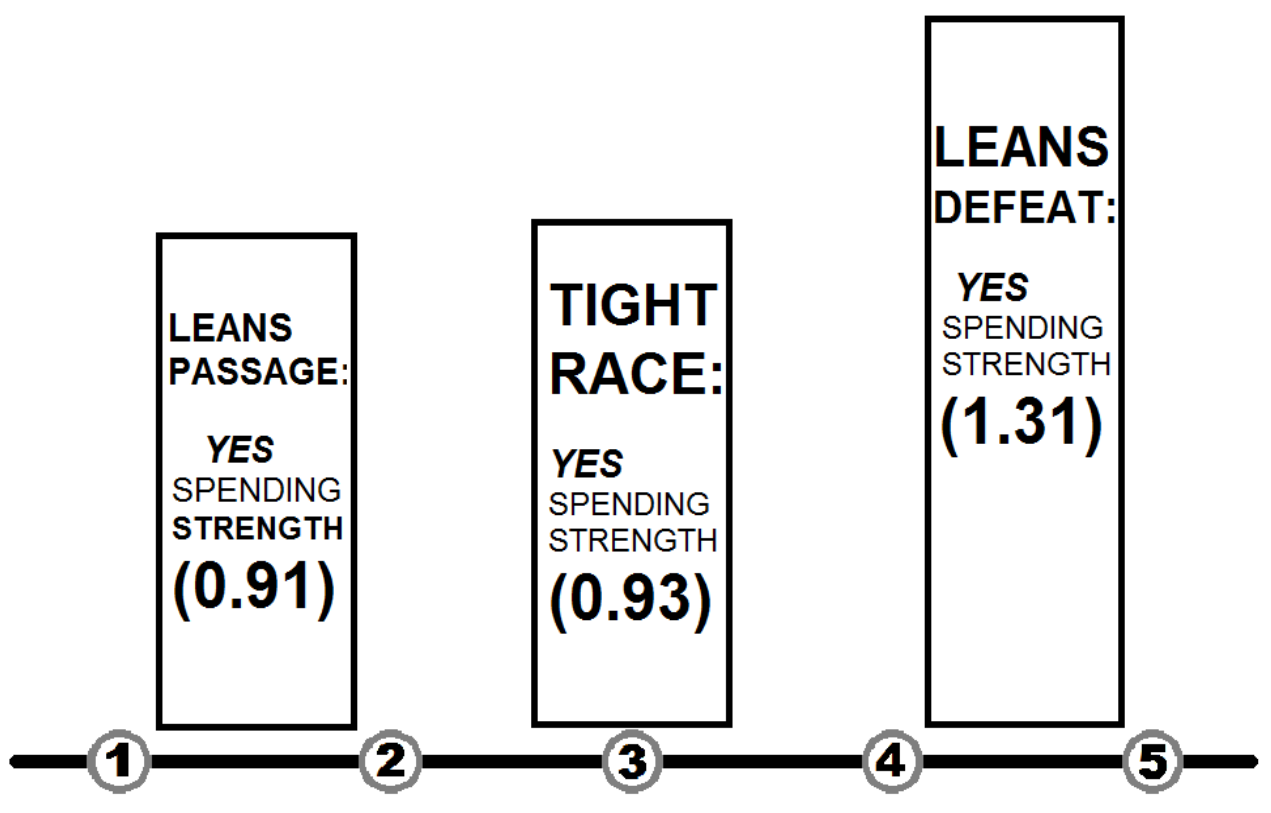

FIGURE 4.1.7: Mean Yes spending strength of initiative contests typed into condensed competitive dynamic categories

The Yes spending strength is greatest in contests which lean towards defeat. Yes campaigns spent the least strongly when the contest leaned towards passage. The relationship was not as distinct as the relationship between condensed categories and No spending strength. In sum, the strategic financing demonstrated by the data in Figure 4.1.7 would distort estimates of the effectiveness of Yes spending downwards towards zero.

Figure 4.1.8 contains No campaign mean spending strength numbers, sorted by the 3 condensed competitiveness categories. The results show that No money tended to be strongest in tight races and weakest in those situation which lean towards passage. 


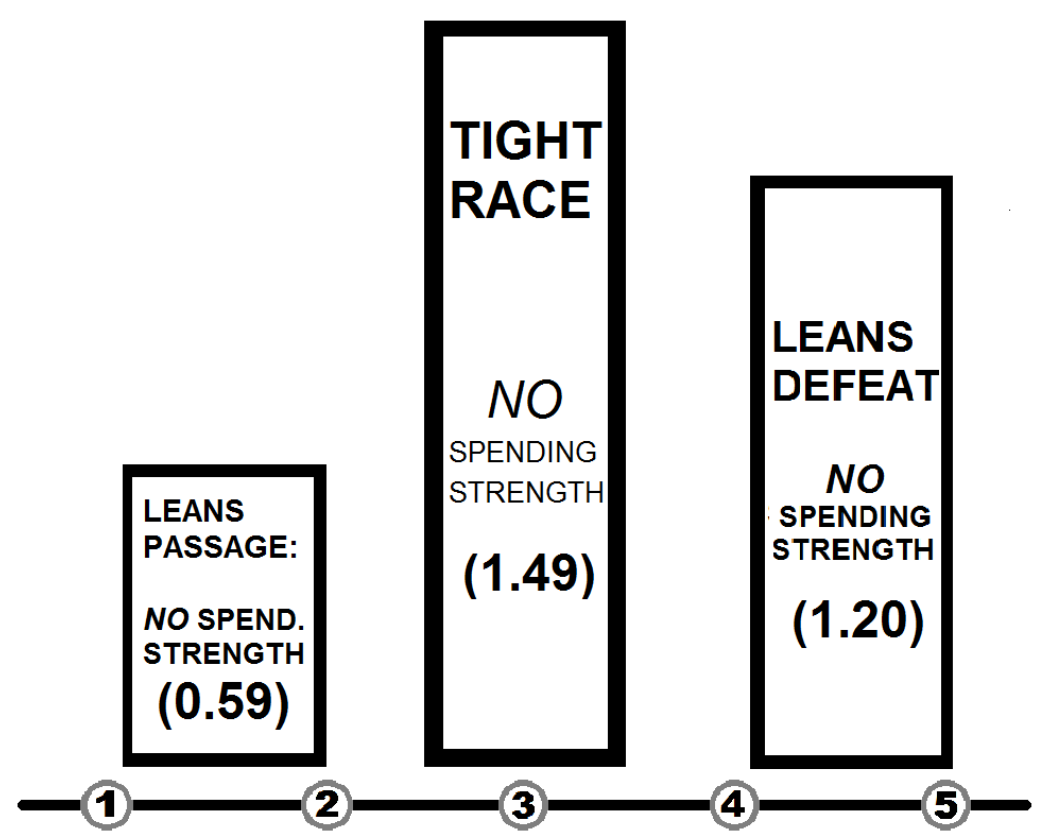

FIGURE 4.1.8: Mean No spending strength of initiative contests typed by condensed competitive dynamic categories

No spending is strongest in situations where the competitive dynamic suggests a tight race. No spending was weakest in races that were likely to end in passage.

Furthermore, No spending was, on average, twice as strong in contests that leaned towards defeat as it was in contests that leaned towards passage. This provides evidence that No campaigns are either unable or unwilling to put resources into contests that are likely to win, and most likely to spend the strongest in tight-races. In general this strategic financing of No campaigns would cause researchers to overestimate the effectiveness of No spending. 


\section{Design \#2: Wilson typing and initiative contest outcomes}

Below, Figure 4.2.1 contains a representation of how contest types were distributed within the dataset.

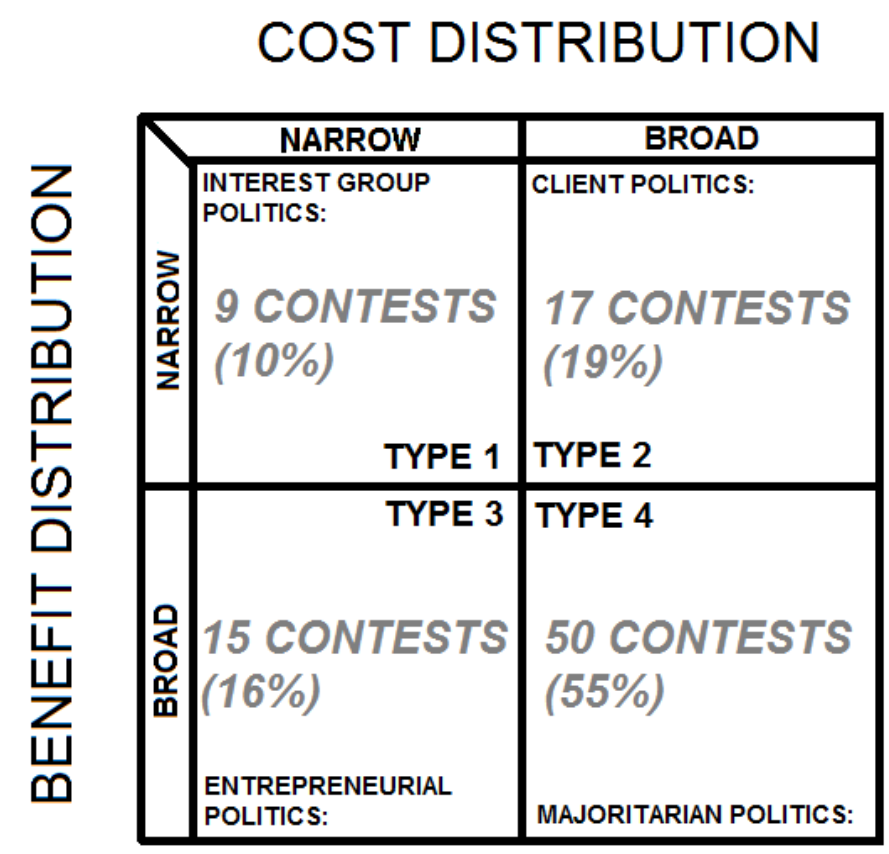

FIGURE 4.2.1: Wilson types - total occurrences and percentages of sample

An unrivaled majority (55\%) of the contests fall within the Majoritarian Politics category.

The least contests occur in the Interest Group Politics category (10\%). Occurrences of initiative contestation appear to be closely correlated to the presence of broad policy stakes on either side of the Yes/No divide.

Figure 4.2.2, seen below, shows the passage rates of Wilson-typed contests. The Wilson typing contains a distribution of passage rates that suggests significant association 
between broad benefits and increasing passage rates. The same holds true, though slightly less so, for an association between broad costs and increasing passage rates.

\section{COST DISTRIBUTION}

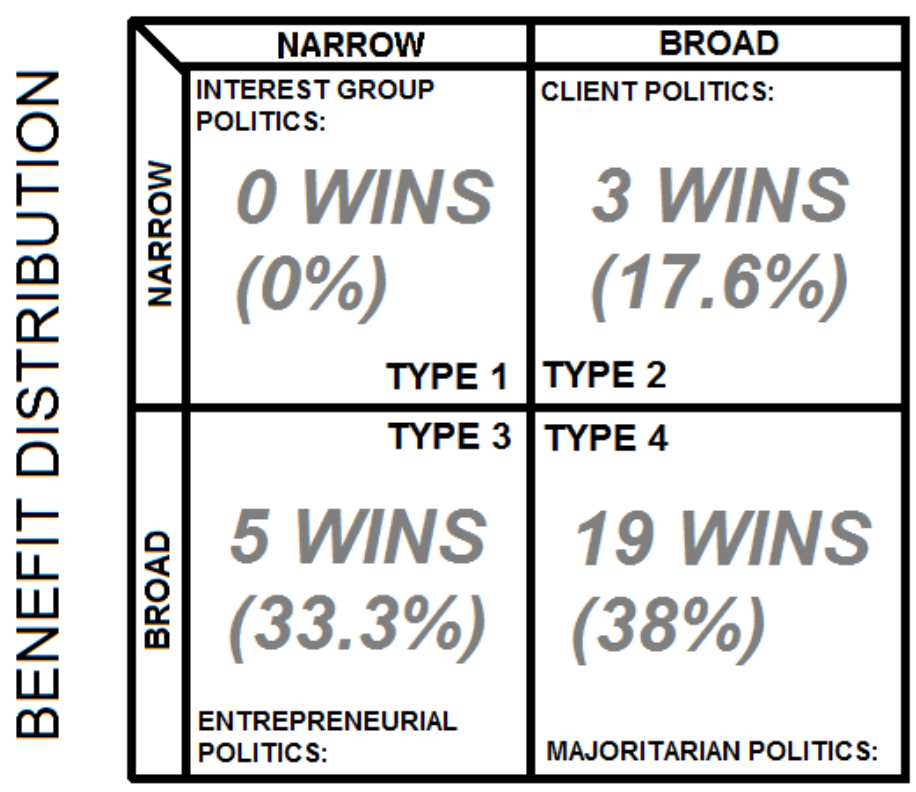

FIGURE 4.2.2: Initiative passage distribution across Wilson-typed contests

The passage rate for the entire sample was $29.7 \%$. If Types 3 and 4 contests are aggregated to show the passage rate for contests where broad benefits were being contested, the passage rate for this category is $37 \%$. Conversely, the passage rate for contests with narrow benefits (Types 1 and 2) was a meager 11.5. At $38 \%$ the passage rate is the highest for Majoritarian Politics-type situations. Passage rates were second highest for Entrepreneurial Politics contests. Entrepreneurial politics contests seldom ended in passage (17\%). Zero of the Interest Group Politics contests ended in passage. 
The next graphic (Fig. 4.2.3) shows the distribution of mean Yes voting within the Wilson-typed sample of contests. As was expected given the passage rate distribution, the largest mean Yes voting was solidly within the Majoritarian Politics category.

\section{COST DISTRIBUTION}

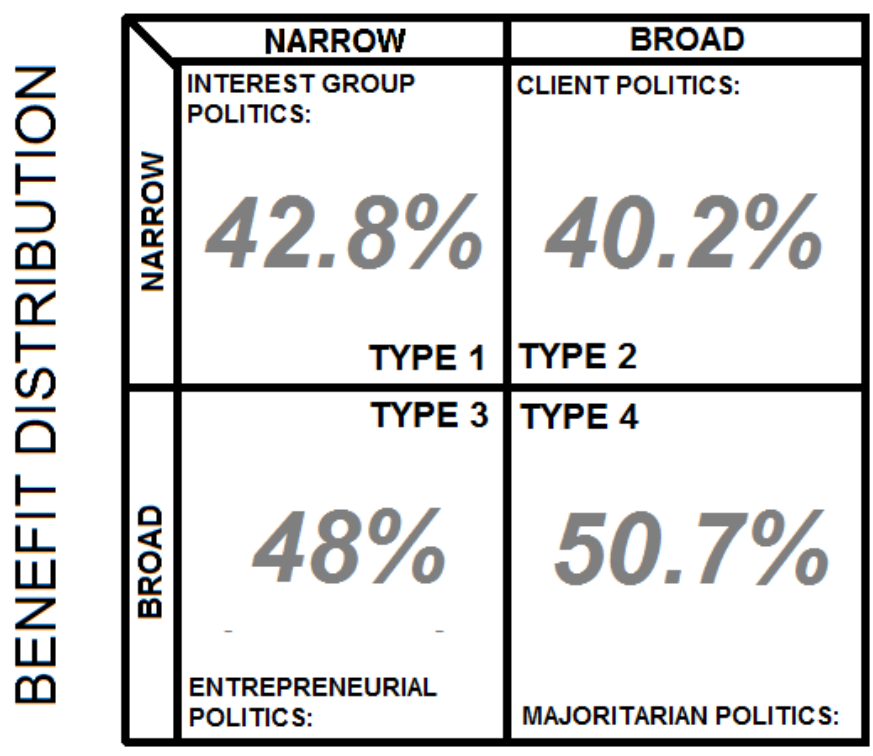

FIGURE 4.2.3: Distribution of mean Yes-voting across Wilson-typed contest

Entrepreneurial Politics has a very respectable $48 \%$ mean Yes voting rate, making it a close second to Majoritarian Politics across this dimension. As with passage rates, a broad benefitting contest (Types 3 and 4) attracts the most Yes voting on average.

At this point in the analysis, campaign finance data is integrated into the 91 initiative contest dataset of Design \#2. A measure of Spending Strength for Yes and No campaigns was constructed in order to hold initiative spending levels relative to the scope of campaign spending required to compete within the specific context of a given state. Figure 4.2.2 shows how the spending strength of Yes campaigns was distributed across the 4 Wilson types. 


\section{COST DISTRIBUTION}

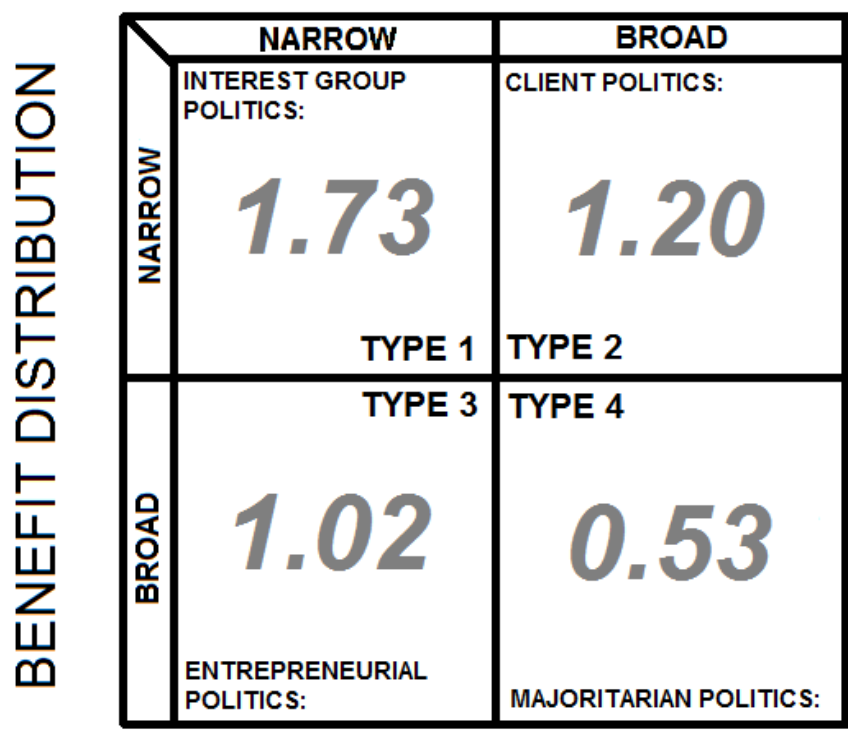

FIGURE 4.2.4: Mean Yes spending strength distribution of Wilson typed-contests

This distribution is very much the inverse of the earlier distributions. Yes campaign spending strength is closely and positively related to the engagement of narrow interests, particularly narrow benefits. Interest Group contests between narrow interests have the strongest Yes spending by far for any category. Majoritarian conflicts have an equally decisive lack of spending strength for Yes campaigns.

In Figure 4.2.5, the analysis turns to No spending. No campaign spending strength averages are presented across Wilson-typed contest distribution. Interest Group Politics situations have by far the greatest mean No spending strength. Narrow-benefitting contests have, on average, over twice as much spending strength behind their No campaigns. 


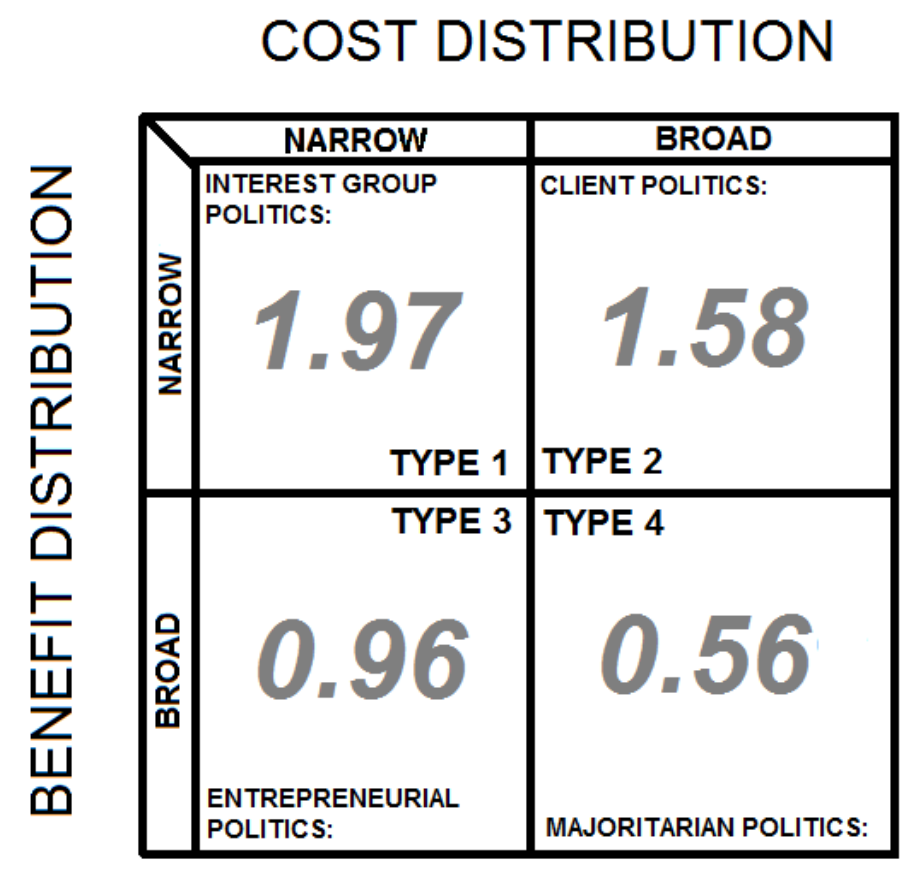

FIGURE 4.2.5: Mean No spending strength distribution of Wilson typed-contests

Overall, the results map out over the Yes spending strength results with remarkable consistency. The least No campaign spending strength was found within Majoritarian Politics situation. 
Design \#3: Party Politics and the Initiative Process

\begin{tabular}{|c|c|}
\hline BALLOT & CORRELATION BETWEEN YES \\
MEASURE & VOTING AND DEMOCRATIC AFFILLIATION \\
\hline $\mathbf{9 / O R / 2 0 0 0 ~}$ & $-\mathbf{0 . 9 4 1 7}$ \\
\hline $87 / O R / 2000$ & -0.6019 \\
\hline $95 / O R / 2000$ & -0.8161 \\
\hline $5 / 2000 / O R$ & $\mathbf{0 . 9 2 8 9}$ \\
\hline $25 / O R / 2002$ & 0.6696 \\
\hline $36 /$ OR/2004 & 0.8861 \\
\hline $37 / O R / 2004$ & -0.8119 \\
\hline $35 / O R / 2004$ & -0.8192 \\
\hline $14 / O R / 2004$ & 0.8291 \\
\hline $43 / O R / 2006$ & -0.8975 \\
\hline $40 / O R / 2006$ & -0.9315 \\
\hline $48 / O R / 2006$ & -0.5952 \\
\hline $42 / O R / 2006$ & -0.4489 \\
\hline $47 / O R / 2006$ & -0.4933 \\
\hline
\end{tabular}

Table 3: Coefficients of correlations between a county's Yes voting on a ballot measure and its level of connection with the Democratic Party

In Table 3, seen above, the correlational coefficient is presented for each initiative contest between county-level Yes voting and Democratic Party attachment. Coefficients range from a high of 0.9289 for Oregon's 2000 Measure 5, to a low of -0.9417 for Oregon's 2000 Measure 9. The closest any contest's coefficient came to zero was 0.4489 for Oregon's 2006 Measure 42. Six of the measures were correlated below -0.8. Three of the measures were correlated above 0.8 . Five of the measures correlated somewhere between -0.8 and 0.8 . 


\section{- Chapter 5 - \\ Discussion}

This chapter begins with a discussion of the results of Design \#1. This author interprets that the data shows strategic decision-making in the financing of Yes and No campaigns. Policy-demanding individuals and groups gave the most money to initiatives that appeared in danger of going "the wrong way." Next, the results from Design \#2 are discussed. Evidence will be discussed which documented a recurrent pattern wherein broad interest engagement is connected to weak spending values and high passage rates. The inverse is also true, a trend connects narrow interest engagement in contests with high spending levels and low passage rates.

Finally, the results for Design \#3 will be examined. In Design \#3, variation was observed as to whether or not initiatives relied moderately or highly on partisanstructured coalitions to constitute their Yes vote. Additionally, considerable variation was also observed in regards to which side of the partisan divide initiatives built their Yes coalitions with.

This chapter then evaluates the hypotheses provided earlier in the Methods chapter. The hypotheses were all supported, to one degree or another, by the findings. This chapter then concluded with a discussion of the limitations of this study and an evaluation of how future research should proceed. 


\section{Design \#1: Picking Losers?}

This analysis was built around claims about the strategic behavior of the policydemanders who finance initiative campaigns. Does Yes money really tend to flow towards floundering initiative efforts? Does the level of campaign spending generally track with the competitiveness of initiative contests?

The testing of the typing instrument demonstrated a reasonable overlap between contest typing and contest outcomes. In terms of both passage rates and mean Yes voting. The measures of spending strength were presented in the context of condensed contest categories in Figures 4.1.9 and 4.1.10. The mean Yes spending strength was lowest in situations which leaned towards passage, and rose as the probability of defeat increased. Interestingly, the most dramatic association between competitiveness and mean Yes spending strength occurred in situations which leaned most heavily towards defeat. This relationship provides support for the assumption built into recent research which controls for a tendency of Yes money to be made available to more vulnerable initiatives. ${ }^{143}$

The mean No spending strength distribution contains an even more dramatic level of variation. No campaigns had the strongest spending in tight races. In terms of strategic behavior, No-demanding actors appeared to have one tendency which ran opposite from Yes-demanding actors. Yes-demanding actors spent the strongest when defeat seemed the most likely. Their commitment to the initiative effort was stickier, and the decision to cut their losses when the odds changed was more difficult.

${ }^{143}$ Stratmann (2005), de Figueiredo et al. (2011) 
No-demanding actors spent the least when their disfavored initiatives seemed on course to pass. Perhaps this speaks to the No campaigns' tendency to have an easier time cutting off funding to initiative efforts once evidence suggests they are futile.

\section{Design \#2: Majoritarian initiative success on the cheap?}

The results of Design \#2 largely comport with the findings of other researchers who used the Wilson typology within the context of the initiative process. In keeping with past studies, a majority of initiative contests were found to be situations of Majoritarian Politics. Moreover, Entrepreneurial Politics contests covered another $16 \%$ of the sample. This means that $71 \%$ of the initiative contests concerned policy changes which would have brought broadly distributed benefits to the citizenry. Passage rates were highest for majoritarian initiatives. This underlines some of the normative implications made about the distribution of occurrences of different contest types. Passage rates are significantly higher for contests which benefit broad groups.

Mean Yes spending strength was the highest in Interest Group Politics contests. This corresponds with the strategic behavior expected of individuals and groups. A narrow group has the resources to spend strongly to support its interests. If that narrow group is in competition with another narrow, well-financed interest, then it makes sense that the spending would be the strongest.

Mean Yes spending strength was the lowest for Majoritarian Politics-type initiative contests. It was less than one third that of Interest Group Politics-type contests. 
Once again, these findings comport with the understanding of the logic of collective action. Broad interests have less ability to spend strongly. In the distribution of mean Yes spending across the Wilson typology, Yes spending increases in concert with the opportunities and incentives created by the relative breadth or narrowness of interests at stake in initiative contests.

Strikingly, the Majoritarian Politics-type initiative contests had the highest passage rate. Taken with their relatively small Yes spending strength, this means that situations of majoritarian politics allowed policy-demanders to pass a relatively large amount of initiatives for a low amount of Yes spending. However, the pattern also holds true for narrow-narrow contests. Interest Group Politics-type contests had the highest levels of Yes spending strength, and zero passages to show for it.

This means that both Yes and No money were targeted towards a set of initiatives that were very unlikely to win in the first place. These numbers suggest an omitted variable that could bias estimates of the effectiveness of spending downwards towards zero. In terms of $N o$ spending strength, it was highest in Interest Group Politics-type contests as well. Also, just like Yes spending, No spending was weakest in majoritarian contests. Once again, the logic suggests that No spending strength rises in concert with opportunity and incentive. The relationship between passage rates and estimates of spending efficacy cuts the opposite way. If No spending is targeted towards contests which are likely to fail, then a model that excludes this tendency is likely to overestimate the effectiveness of No spending. 
The results indicate a relationship between an initiative contests Wilson types and 1) its odds of ending in passage and 2) the probable levels of spending. In Figure 5.2.1 below, it has been documented how majoritarian initiative contests provide a strategic situation which, excluded from one's models, makes Yes spending appear less necessary as an ingredient for passage-seekers.

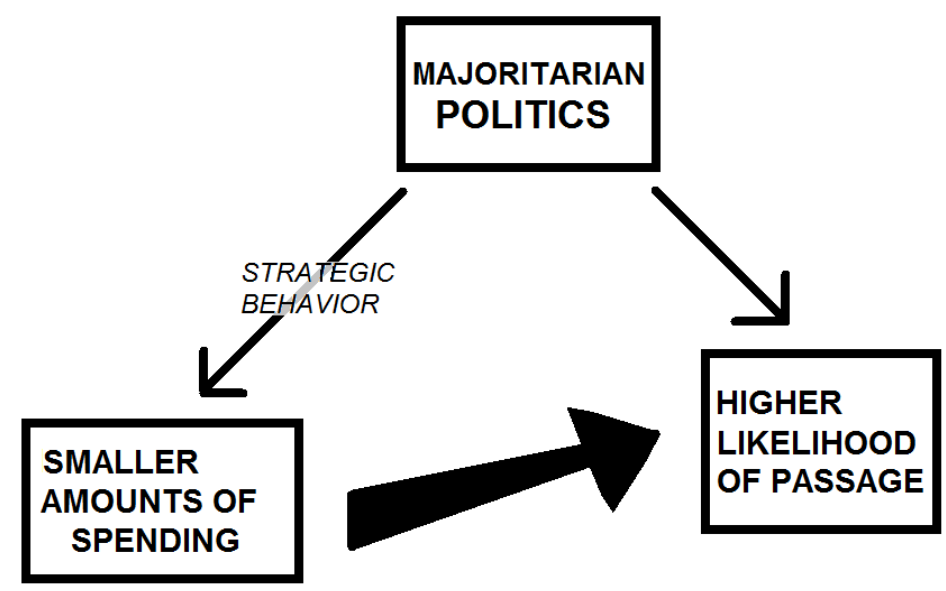

FIGURE 5.2.1: Relationship between majoritarian initiative contests, spending, and passage rates

Figure 5.2.2, seen below, displays the other strategic situation to account for, where narrow actors, particularly when competing with other narrow actors, will pour lots of resources into contests which begin with slim initial odds of passage to work against. Models of the influence of money in initiative contests which turn a blind eye to the tendency of narrow money to "pick losers" will miss the deeper causality which organizes initiative politics. 


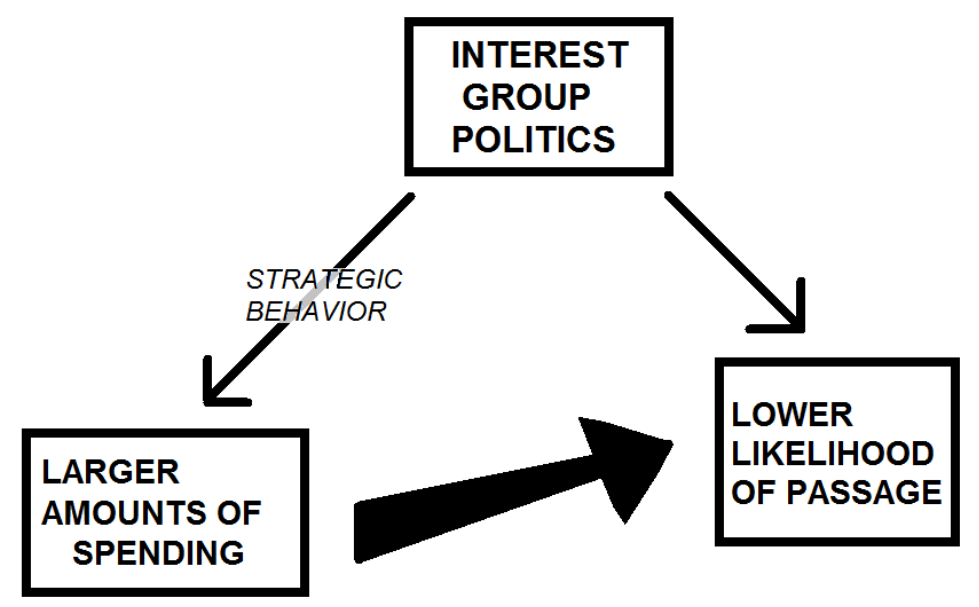

FIGURE 5.2.2: Relationship between narrow-narrow initiative contests, spending, and passage rates

\section{Design \#3: Outside party politics?}

The findings affirmed the expectations set by Hypotheses 3.1 and 3.2. For several of the initiatives in the 14-contest sample, Democratic affiliation was positively correlated at a coefficient above 0.9. Additionally, there were several initiatives that were negatively correlated at a coefficient below -0.9. Moreover, on many of the initiatives, partisan affiliation was not related to initiative voting in any meaningful way. Though the proportion of this small sample reveals a tendency towards initiatives which rely on Democratic coalitions to turn out Yes votes, the long history of direct democracy suggests that it is not the creature of any one party for any sustained amount of time.

Below, in Figure 5.3.1, a scatterplot shows a correlation between county-level Democratic party-affiliation, and county-level voting on Oregon's 2000 Ballot Measure 5. Ballot Measure 5 was a gun control initiative which would have expanded the circumstances requiring a background check when firearms possession was transferred. 
Measure 5 is featured because it was the contest in the sample where county Democratic affiliation was correlated the strongest to Yes voting. The correlation coefficient was 0.93 .

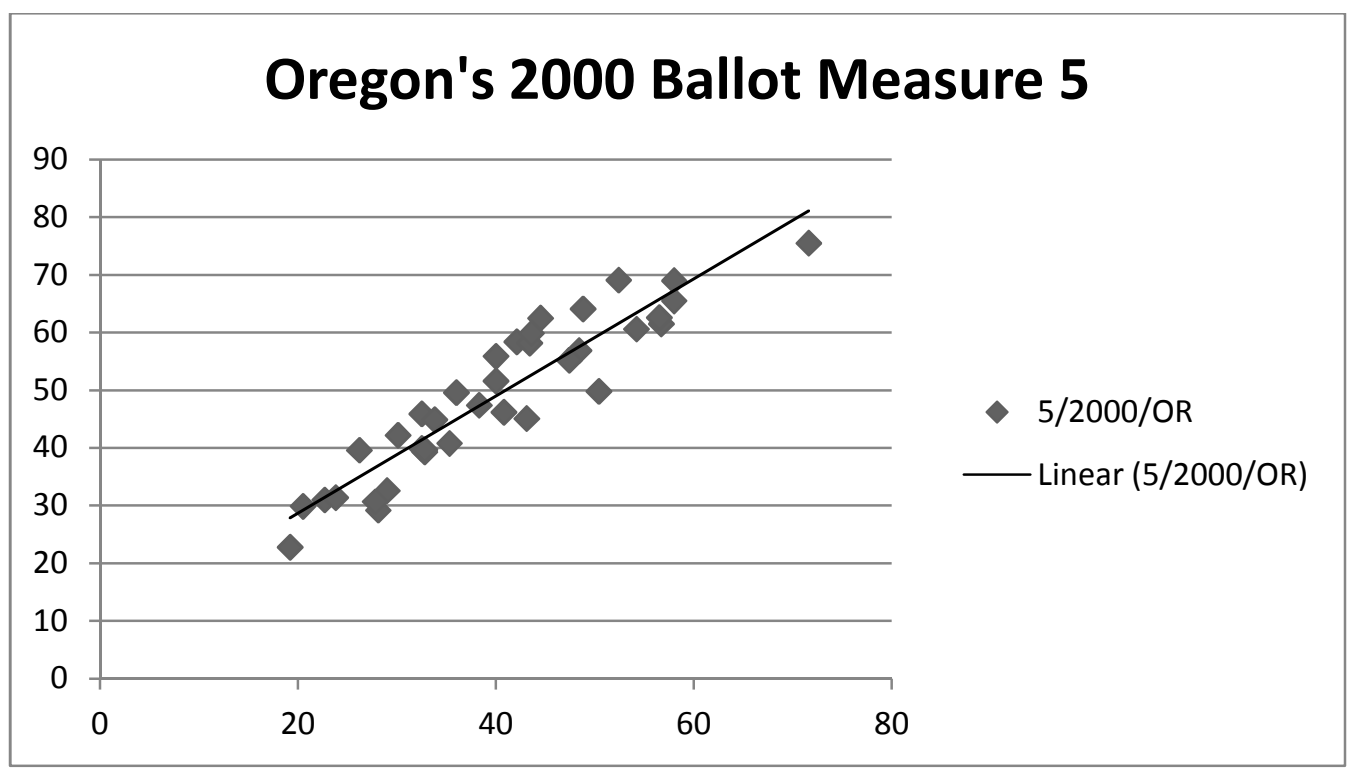

FIGURE 5.3.1: Relationship between county-level Democratic Party affiliations and voting on Oregon's Ballot Measure 5 (2000)

In the example of Ballot Measure 5, a counties' level of affiliation with the Democratic Party was highly and positively correlated with Yes voting. This gun control initiative was passed along almost entirely the same lines of political division as the presidential election that would come 4 years later. The measure apparently relied over $90 \%$ on the same coalition of voters that favor Democratic candidates. 


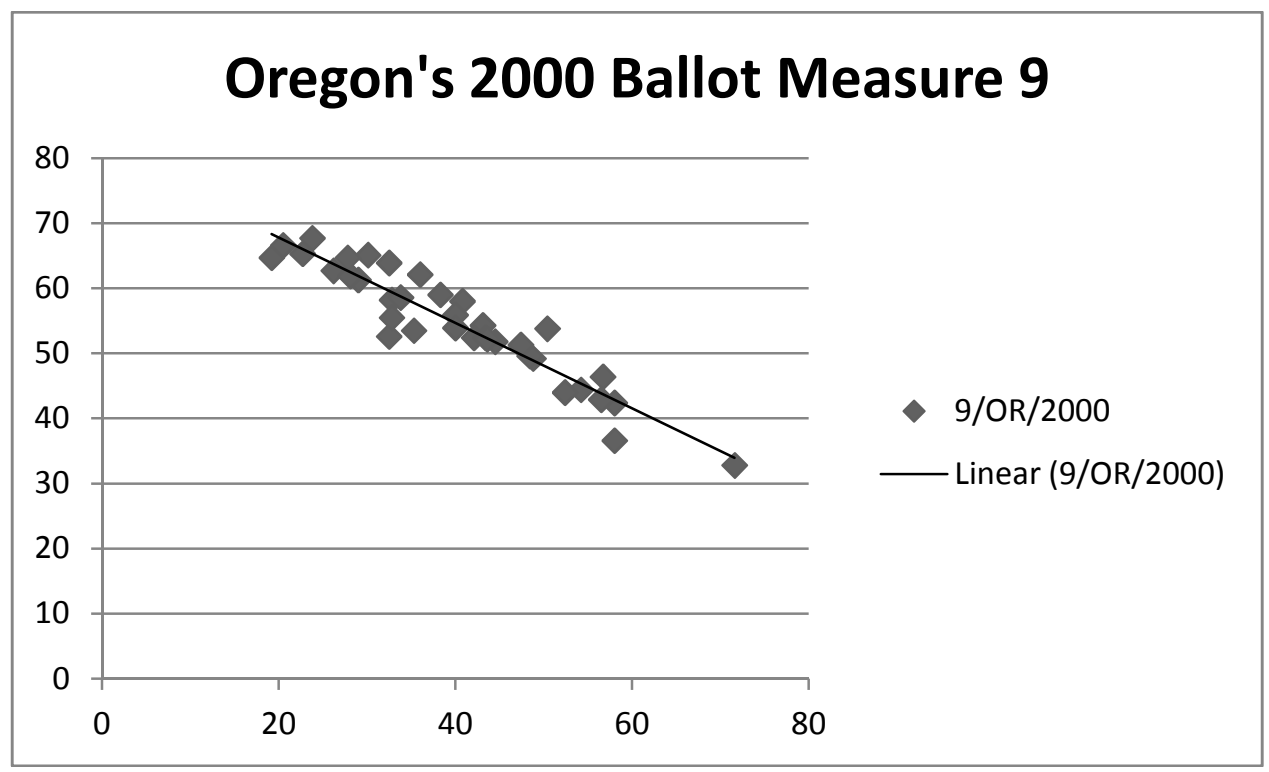

FIGURE 5.3.2: Relationship between county-level Democratic Party affiliations and voting on Oregon's Ballot Measure 9 (2000)

The correlational coefficient was even stronger (-0.9417), though in the opposite direction for Ballot Measure 9. Ballot measure 9 would have prohibited public schools from encouraging, promoting, sanctioning, or instructing on homosexual or bisexual behaviors. Like Ballot Measure 5, this was a classic social issue initiative contest. Figure 5.3.2, seen above, displays a scatterplot comparing a counties' level of Democratic affiliation with its level of Yes voting on Measure 9. Democratic Party affiliation was strongly correlated with lower levels of Yes spending. It should be noted, that in comparison to Fig. 5.3.1's scatterplot on Measure 5, the data points are clustered closer to the linear best fit line. This indicates more consensuses within the Democratic Party on how to vote on Measure 9. 


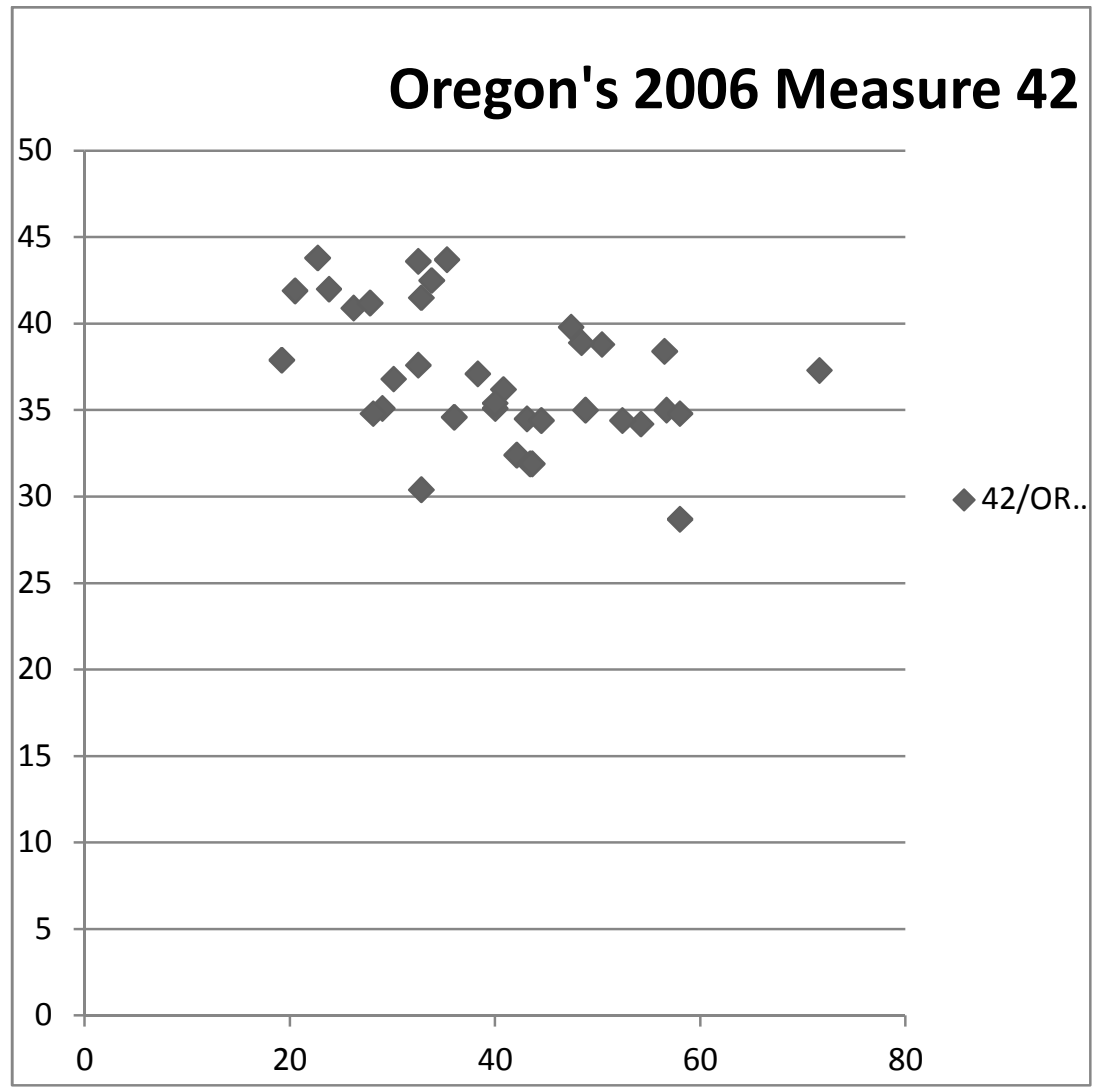

FIGURE 5.3.3: Relationship between county-level Democratic Party affiliations and voting on Oregon's Ballot Measure 42 (2006)

In Figure 3.3.3, seen above, a scatterplot is featured which illustrates the relationship between a counties' level of Democratic affiliation and its level of Yes voting on Measure 42. Measure 42 was featured because it was in this correlational analysis that the lowest level of significance was found. The correlation coefficient was -0.4489. Measure 42 was an insurance regulation reform initiative. It is either an Interest Group Politics or a Client Politics situation initiative via the Wilson typology. It makes sense from a theoretical point of view that interest group politics around a low-salience issue would produce this sort of voting, where party affiliation seems to be a minimal factor in organizing behavior. However, it should be noted that the low correlation in this instance 
is probable more a case of the poor performance of Measure 42 across all categories. The measure failed with a meager $35 \%$ Yes vote.

Overall, the small sample of 14 contests ranged from high to moderate levels of association between county-level initiative voting and partisan attachment. This suggests that, even if parties do not control initiative politics on an organizational level, partisan loyalties in the legislature are critical to shaping a voter's decisions in the initiative arena. The findings here cast doubt on the notion that ballot initiative contests exists outside of party politics in some substantive way.

\section{Conclusions}

Hypotheses \#1.1 and 1.2 pertain to a tendency for spending to be made available in more competitive situations. Hypothesis \#1.1 predicted that Yes spending would be weakest in contests which leaned the hardest towards passage and strongest in contests which leaned the most towards defeat. Figure 4.1.8 illustrates the data which affirmed this hypothesis. Hypothesis \#1.2 predicted that the spending for No campaigns would be strongest in the most competitive (Type 3) situations. The findings, displayed in Figure 4.1.9, affirmed this hypothesis.

Hypotheses \#2.1 - 2.5 pertained to Design \#2. Hypothesis \#2.1 predicted which situations spending strength would be the highest and the lowest for Yes and No campaigns. The findings supported the hypotheses. Spending strength for both Yes and No campaigns was strongest in situations of Interest Group Politics and weakest for Majoritarian Politics. Furthermore, Hypothesis \#2.2 and 2.3 were also confirmed by the 
data - high spending strength was associated with narrow costs and benefits, and low spending strength was associated with broad costs and benefits. Hypotheses \#2.4 - 2.6 anticipated that passage rates would be associated with Wilson type in the opposite way as campaign spending strength. Majoritarian politics and broad interests would be associated with high passage rates. Narrow interests and interest group politics were associated with low passage rates. These hypotheses were borne out by the results of the analyses.

Hypotheses \#3.1 and 3.2 were written for Design \#3. The first hypothesis (\#3.1) predicted variability in the degree of association between county-level partisan attachment and Yes voting on initiatives. The levels of association actually varied only from moderate to very high levels of correlation, with no examples of distributions that didn't map at least moderately closely over the structure of partisan attachments. Sometimes partisan attachment maps out over the Yes voting in a manner that makes them look like virtually the same thing. At other times they appear to be moderately less determinative. In sum, the evidence here suggests that ballot initiative contests do not take place outside or independent of party politics in any truly substantive sense. The second hypothesis (\#3.2) predicted variability in the directionality of association, if and where it did exist. This hypothesis was affirmed by the findings, wherein there were several highly significant associations in both directions within a relatively small sample. 


\section{Limitations}

This section accounts for the limitations of the research design. First come some broad explanatory limitations related to generalizability, contingency, and the heterogeneity of variables. At this point, the section then goes through the limitations of each of the three research designs, beginning with Design \#1 and ending with Design \#3.

The first set of limitations pertains to generalizability. Whether dealing with money, breadth of interests engaged, or institutional conditions, it is difficult to generate evidence of specific initiatives passing and failing which can support general conclusions about why passage occurred when it did. Claims can hypothetically gain generalizability if the sample were expanded to gain more cases across more contests. However, gains in scope and parsimony can come with an explanatory blindness to contingency. This thesis looks at data from $21^{\text {st }}$ century initiative contests in California, Oregon, and Washington. It would require caution to generalize from observations of this sample to initiative politics in other times and places.

Under Design \#1, polling data was used to classify the competitive dynamic of initiative contests. Polling data was not available for every initiative contest. The initiative contests with sufficient polling data were obviously not randomly selected. It is probable that poling data was systemically inclined to focus dominantly on high-salience contests at the exclusion of more low-profile contests. This might play a role in explaining why so few narrow-narrow contests were observed in the sample. Sampling errors like these critically limit the generalizability of claims made in Design \#1. 
Generalizations based on patterns in the sample do not apply beyond high-salience contests.

Explanations of initiative contest outcomes are also limited by the contingency of the political environment. Many authors have observed emerging changes in the basic dynamics of political competition. ${ }^{144}$ Changes in initiative politics (across states, issue areas, and time periods) limit the transferability of any conclusions researchers can draw about what causes initiative contests outcomes.

In regards to Design \#1, the survey research was not available for every initiative contest. Moreover, it was not distributed uniformly within the contests for which it was available. Therefore, whatever qualities made it more likely for an initiative to generate polling data, those qualities distorted any attempt to draw conclusions about the initaitve process in generalized terms.

Resources limitations constrained this study's ability to develop and implement intercoder reliability procedures in Design \#2 when the Wilsonian classification was performed. Intercoder reliability procedures could have incorporated a larger number of coders to better achieve their purpose. Additionally, Wilson typing is inherently laden with subjectivity. The analysis under Design \#2 is limited by the capacity for researcher bias to guide classification into the four Wilson categories of cost-benefit distribution.

In Design \#3, for simplicity's sake, county-level partisan attachment was was represented in terms of John Kerry's vote percentage in the 2004 presidential election. There are endless reasons why this would fail to capture Democratic attachment, from candidate charisma to some other particularity of that year (2004) which does not hold

\footnotetext{
${ }^{144}$ Smith and Tolbert, "The Initiative to Party"; McCuan and Stambough, Initiative-Centered Politics.
} 
true for the whole sample (2006 - 2000). This study's measures of partisan attachment are limited by the degree to which a county's vote for John Kerry in 2004 falls short of capturing its democratic attachment from 2006 to 2000.

\section{Further research}

Future studies should look to the recurrent situations documented in Design's \#1 and 2 to inform the econometric techniques applied to measure the influence of money. In regards to Approach \#2, future studies should look at the relationship between Wilson type and the regulations surrounding the initiative. Do regulations on the initiative process affect what qualifies and passes in terms of distribution of Wilson types. This study has provided some broad evidence suggesting that the initiative process allows diffuse interests to overcome collective action problems. Future research should rigorously elaborate how the initiative process helps groups activate latent interests and overcome collective action problems. The conditions and mechanisms underlying this process must be better understood through future research.

Though this author has attempted some basic efforts, the normative implications remain to be unpacked of the tendency, observed in this study as well as others, ${ }^{145}$ for the initiative process to promote participation and passage for broad interests with limited resources. In relation to an earlier observation, future studies should unpack the implications of how best to regulate an initiative arena organized by "majoritarian" political conflicts.

\footnotetext{
${ }^{145}$ Campbell, “The Citizen's Initiative and Entrepreneurial Politics”; Donovan et al., "Contending Players and Strategies"; McCuan, Can't Buy Me Love"; de Figueiredo et al., "Financing Direct Democracy." 
Additionally, Wilson typing procedures inherently lack some precision, but improvements could still be made by incorporating more coders and establishing more rigorous procedures for selecting and briefing the coders. This study incorporated this author's assessment of the concentration of contributions within a measure committee's records. However, future studies could supplement a content analysis of initiatives with a more quantitatively precise procedure for measuring the relative concentration or diffusion of contributions - that is to say, measuring whether an initiative committee's war chest is composed of many small donations or a few huge donations. This kind of design would build onto the efforts of Braunstein. ${ }^{146}$ A technique such as this would build further reliability and validity into Wilson typing procedures through incorporating a measure of felt stakes in initiative outcomes.

Further research into explaining initiative success should embrace this study's emphasis on the power of institutionally-embedded explanations. The ballot initiative process as an institution of policymaking needs to be better understood both in its own institutional terms and in the broader context of other the policymaking institutions with which it shares power. Future studies should examine variations in success rates between contests with varying degrees of alignment with partisan attachments. Multistate analyses should look at whether successful initiatives are more often built on non-party coalition or the coalitions of parties. Furthermore, multistate analyses should answer whether success was more often related to significant reliance on a party coalition which is respectively in or out of power in the statehouse.

\footnotetext{
${ }^{146}$ Braunstein, "The Impact of Campaign Finance on Ballot Issue Outcomes."
} 
Though omitted from this paper, explanations must be considered which examine the importance of sequencing. How do the determinants of success in the ballot initiative process transform in response to an election year's cyclical status as presidential, midterm, or off-year? There is potential for a fascinating study which compares and contrasts ballot initiative politics between political cycles. The practical applications of such a study could be enormous if it could effectively forecast the ideal year for trying to pass a specific initiative.

Finally, future studies of the initiative process must describe nonpassage objectives of initiative campaigns, and explain the degree to which these objectives can operate independently from passage objectives to motivate initiative actors. Ballot initiative politics is a dynamic and under-investigated institution of policymaking. Going forward, explanations of ballot initiative contests must acknowledge the range of passage and nonpassage motivations which combine at the site of initiative politics to affect changes in the processes, products, and politics of democratic government. 


\section{References}

Allen, Ronald J. "The National Initiative Proposal: A Preliminary Analysis," Nebraska Law Review, Vol. 58, (1979) pgs. 1034-1036.

Ansolabehere, Stephen, John de Figueiredo, and James Snyder. "Why is There so Little Money in U.S. Politics?" The Journal of Economic Perspectives, Vol. 17, No.1, (Winter 2003) pgs. 105-130.

Bawn, Kathleen, Martin Cohen, David Karol, Seth Masket, Hans Noel, and John Zaller. "A Theory of Political Parties: Groups, Policy Demands and Nominations in American Politics." Perspectives on Politics, Vol. 10, No.3, (2012) pgs. 571-597.

Besley, Timothy, and Stephen Coate. "Issue Unbundling via Citizens' Initiatives." Quarterly Journal of Political Science, Vol. 3, No. 4, (December 2008) pgs. 379-397.

Bowler, Shaun, and Todd Donovan. Demanding Choices: Opinion, Voting, and Direct Democracy. Ann Arbor: University of Michigan Press, 1998.

Bowler, Shaun, and Todd Donovan, "Economic Conditions and Voting on Ballot Propositions." American Politics Quarterly, Vol 22, No.1, (January 1994) pgs. 27-40.

Braunstein, Richard. "The Impact of Campaign Finance on Ballot Issue Outcomes." In Initiative-Centered Politics: The New Politics of Direct Democracy," edited by David McCuan and Steve Stambough. Durham: Carolina Academic Press, 2005.

California Business Roundtable website. "Studies and Resources." California Business Roundtable and Pepperdine University School of Public Policy. Accessed online on August $15^{\text {th }}, 2013$. < http://www.cbrt.org/studies-resources/>

California Secretary of State website. "Cal-Access Database.” California Secretary of State. Accessed online on August 20 ${ }^{\text {th }}, 2013$. <http://calaccess.ss.ca.gov/Campaign/>

California Secretary of State website. "Statewide Elections: 2012-1990." California Secretary of State. Accessed online on August 25 th 2013. <http://www.sos.ca.gov/elections/statewide-elections/>

Campbell, Anne G. Setting the Initiative Agenda: The Not-So-Silent Majority. Phd dissertation, University of Colorado Department of Political Science. Ann Arbor: UMI Company, 1998. 
Campbell, Anne G., "The Citizen's Initiative and Entrepreneurial Politics: Direct Democracy in Colorado, 1966-1994." Paper presented at the Annual Meeting of the Western Political Science Association, Tucson, AZ (March 1997).

Carmines, Edward G. and James A. Stimson. Issue Evolution: Race and the Transformation of American Politics. Princeton NJ: Princeton University Press, 1989.

Coate, Stephen. "Pareto improving campaign finance policy," American Economic Review, Vol. 94, No. 3, (2004) pgs. 628-655.

Cobb, Roger W., and Charles D. Elder. Participation in American Politics: The Dynamics of Agenda-Building. Boston: Allyn and Bacon, 1972, 1983.

Coleman, James. Foundations of Social Control, Cambridge: Belknap Press of Harvard University, 1998.

Cook, Timothy E. Making Laws and Making News. Washington DC: The Brookings Institution, 1989.

Cronin, Thomas E. Direct Democracy: The Politics of Initiative, Referendum, and Recall. Cambridge: Harvard University Press, 1989.

de Figueiredo, John, Chi Ho Ji, and Thad Kousser, "Financing Direct Democracy: Revisiting the Research on Campaign Spending and Citizen Initiatives," The Journal of Law, Economics, \& Organization, Vol. 37, No. 3 (2011).

Donovan, Todd, Shaun Bowler, David McCuan, and Ken Hernandez, "Contending Players and Strategies: Opposition Advantages in Initiative Campaigns," In Citizens as Legislators: Direct Democracy in the United States, Eds. Todd Donovan, Shaun Bowler, and Caroline Tolbert, Columbus: Ohio State University Press, (1998) pgs. 80-104.

Dunn, William. Public Policy Analysis, Fifth Edition. Pearson Press, 2011.

Elway Research website. “The Elway Poll.” Elway Research, Inc. Accessed online on August $15^{\text {th }}, 2013$. <http://www.elwayresearch.com/elwaypoll.html $>$

Field Poll website. "Poll Archive." Filed Poll. Accessed online on August 15 ${ }^{\text {th }}, 2013$. $<$ http://www.field.com/fieldpollonline/subscribers/>

Garrett, Elizabeth, and Elisabeth Gerber. "Money in the Initiative and Referendum Process: Evidence of its effects and prospects for reform." In The Battle Over 
Citizen Lawmaking, edited by M. Dane Waters. Durham: Carolina Academic Press, 2001.

Gerber, Elizabeth. "Direct Democracy." In Elgar Handbook on Public Law and Public Choice, edited by D.A. Farber and A.J. O'Connell, Massachusetts: Edward Publishing Group, 2010.

Hacker, Jacob S., and Paul Pierson. Winner-Take-All Politics: How Washington Made the Rich Richer - and Turned Its Back on the Middle Class. Boston: Simon \& Schuster, 2011.

Heiser, P.F., and M.E. Begay. "The Campaign to Raise the Tobacco Tax in Massachusetts.” American Journal of Public Health, Vol. 87, No. 6, (June 1997) pgs. 968-973.

Hero, Rodney, Faces of Inequality: Social Diversity in American Politics. Oxford University Press, 2000.

Jacobson, Gary. "Money and Votes Reconsidered: Congressional Elections 1972-1982." Public Choice, Vol. 47, (1985) pgs. 7-62.

Jacobson, Gary C. Money in Congressional Elections. Cumberland: Yale University Press, 1980.

Ipsos website. "Reuters Polls." Ipsos/Reuters Poll. Accessed online on August 15 ${ }^{\text {th }}, 2013$. <http://www.ipsos-na.com/news-polls/reuters-polls/>

Ji, Chang Ho. “California's Direct Democracy 1976-1998: Predictors, Outcome, and Issues." Paper presented at the Annual Meeting of the Western Political Science Association, Seattle, 1998.

Kau, James B. Donald Keenan, and Paul H. Rubin. "A General Equilibrium Model of Congressional Voting." The Quarterly Journal of Economics, Vol. 2, (1982) pgs. 271-293.

Kingdon, John W. Agendas, Alternatives, and Public Policies. Harper Collins Publishers, 1984.

Lascher Jr., Edward L., Michael G. Hagen, and Steven A. Rochlin. "Gun Behind the Door? Ballot Initiatives, State Policies and Public Opinion." The Journal of Politics, Vol. 58, No. 3, (August 1996) pgs. 760-775.

Lee, Eugene C. "California." In Referendums: A Comparative Study of Practice and Theory, edited by David Butler and Austin Ranney. Washington D.C.: AEI, 1978. 
Little, Daniel. "Causing public opinion," Understanding Society. Accessed online on September $16^{\text {th }}$, 2013. (Published Nov. 7, 2008) <http://understandingsociety. blogspot.com/2008/11/causing-public-opinion.html>

Little, Daniel. "Explanatory Autonomy and Coleman's Boat.” Theoria, (2012) pgs. 137-151.

Little Daniel, "Microfoundationalism," Understanding Society, accessed online on September $2^{\text {nd }}, 2013$, (June 28, 2011) <http://understandingsocietyglobaledition. wordpress.com/2011/06/28/microfoundationalism/>

Little, Daniel. Varieties of Social Explanation. Boulder: Westview Press, 1991.

Lowenstein, David. "Campaign Spending and Ballot Propositions: Recent Experience, Public Choice Theory, and the First Amendment." UCLA Law Review, Vol. 86 (1982)

Lowi, Theodore J. "Four Systems of Policy, Politics, and Choice." Public Administration Review, Vol. 32, No. 4, (1972) pgs. 298-310.

Lupia, Arthur, and John Matsusaka. "Direct Democracy: New Approaches to Old Questions, Annual Review of Political Science, Vol. 7, (2004) pgs. 463-482.

Lydenberg, Steven. Bankrolling Ballots: The Role of Business in Financing State Ballot Question Campaigns. Council on Economic Priorities, 1979.

Oregon Secretary of State website. "ORESTAR Database." Oregon Secretary of State. Accessed online on August $20^{\text {th }}, 2013$. 〈http://oregonvotes.org/index.html>

Magelby, David. "Direct Elections in the United States." In Referendums Around the World, edited by David Butler and Austin Ranney. Washington, DC: The AEI Press, 1994.

Magelby, David. Direct Legislation: Voting on Ballot Propositions in the United States. Baltimore: John Hopkins University Press, 1984.

Mastro, Randy M., Deborah C. Costlow, and Heidi P. Sanchez. "Taking the Initiative: Corporate Control of the Referendum Process Through Media Spending and What to Do About It." Federal Communications Law Journal, Vol. 32, (1980) pgs. 315-269.

Mastsusaka, John G. For the Many or the Few? The Initiative Public Policy, and American Democracy. Chicago: University of Chicago Press, 2004. 
McConnell, Allan. "Policy Success, Policy Failure and Grey Areas In-Between." Journal of Public Policy, Vol. 30, No. 3, (2010) pgs. 245-262.

McCuan, David, and Steve Stambough. Initiative-Centered Politics: The New Politics of Direct Democracy. Durham: Carolina Academic Press, 2005.

McCuan, David. "Can't Buy Me Love: Interest Group Status and the Role of Political Professionals in Direct Democracy." In Initiative-Centered Politics: The New Politics of Direct Democracy," edited by David McCuan and Steve Stambough. Durham: Carolina Academic Press, 2005.

National Institute on Money in State Politics. "State Overview: California 2012." Follow the Money database. Follow the Money website. Accessed online on November $18^{\text {th }}, 2013$.

<www.followthemoney.org/database/state_overview.phtml?s=CA\&y=2012>

Olson, Mancur. The Logic of Collective Action. Cambridge: Harvard University Press, 1965.

Oregon Secretary of State website. "Election History Archive." Oregon Secretary of State. Accessed online on August $20^{\text {th }}, 2013$.

<http://oregonvotes.org/pages/history/archive/index.html >

Owens, John R., and Larry L. Wade. "Campaign Spending on California Ballot Propositions, 1924-1984: Trends and Voting Effects." The Western Political Quarterly, Vol. 39, No. 4, (1986) pgs. 675-689.

Poole, Keith T., and Thomas Romer. "Patterns of Political Action Committee Contributions to the 1980 Campaigns for the U.S. House of Representatives." Public Choice, Vol. 37 (1985).

PPIC website. "Statewide Surveys." Public Policy Institute of California. Accessed online on August 15 ${ }^{\text {th }}, 2013$. < http://www.ppic.org/main/series.asp?i=12>

PPP website. "Polls." Public Policy Polling. Accessed online on August 15 ${ }^{\text {th }}, 2013$. <http://www.publicpolicypolling.com/main/polls/>

Reason-Rupe website. "Reason-Rupe Data Archive." Reason-Rupe. Accessed online on August $15^{\text {th }}, 2013$. 〈http://reason.com/poll/data-archive $>$

Rogers, Todd T., and Joel A. Middleton, "Are Ballot Initiatives Influenced by the Campaigns of Independent Groups? A Precinct-Randomized Field Experiment," HKS Faculty Research Working Paper Series, RWP12-049, (November 2012) . 
Schmidt, David D. Citizen Lawmakers: The Ballot Initiative Revolution. Philadelphia: Temple University Press, 1989.

Shockley, John S. "Direct Democracy, Campaign Finance, and the Courts." University of Miami Law Review, Vol. 39, (1985) pgs. 377-428.

Shockley, John S. The Initiative Process in Colorado Politics: An Assessment. Boulder Bureau of Governmental Research and Services, University of Colorado, 1980.

Sinclair, Barbara. The Transformation of the U.S. Senate. Baltimore: John Hopkins University Press, 1989.

Smith, Daniel A., and Caroline J. Tolbert. "The Initiative to Party: Partisanship and Ballot Initiatives in California." Party Politics, Vol. 7, No. 6, (2001) pgs. 739-757.

Stinchombe, Arthur L. "The Conditions of Fruitfulness of Theorizing About Mechanisms in Social Science." Philosophy of Social Sciences. Vol. 21, No. 3, (Sept. 1991).

Stratmann, Thomas. "Are Contributors Rational? Untangling Strategies of Political Action Committees." Journal of Political Economy, Vol. 100, No. 3, (July 1992) pgs. 647-664.

Stratmann, Thomas. "Some talk: Money in politics. A (partial) review of the literature." Public Choice, Vol. 124, (2005).

Stratmann, Thomas. "The Effectiveness of Money in Ballot Measure Campaigns." Southern California Law Review. Vol. 78 (2005).

Sundquist, James L. Dynamics of the Party System, Revised Edition. Brookings Institution Press, 1983.

Survey USA website. "Election Polls." Survey USA. Accessed online on August 15 , 2013. < http://www.surveyusa.com/electionpolls.aspx >

USC Dornsife website. "PACE/USC Rossier School of Education Poll." University of California Dornsife Rossier School of Education. Accessed online on August $15^{\text {th }}$, 2013. <http://dornsife.usc.edu/unruh/poll/>

USC Dornsife website.’USC Dornsife/Los Angeles Times Poll." University of California Dornsife and Los Angeles Times. Accessed online on August 15 ${ }^{\text {th }}, 2013$. <http://dornsife.usc.edu/usc-dornsife-los-angeles-times-poll/> 
Washington Poll website. "Poll Archives." Accessed online on August 15 $5^{\text {th }}, 2013$. The Washington Poll. 〈http://www.washingtonpoll.org/archives.html>

Washington State Public Disclosure Commission website. "Search the Database." Washington State Public Disclosure Commission. Accessed online on August $20^{\text {th }}$, 2013. <http://www.pdc.wa.gov/MvcQuerySystem/ Committee/ continuing_committees $>$

Washington State Secretary of State website. "Elections \& Voting: Research \& Past Results." Washington State Secretary of State. Accessed online on August 25 ${ }^{\text {th }}$, 2013. 〈http://www.sos.wa.gov/elections/press.aspx >

Weaver, R. Kent, and Bert A. Rockman. "Do Institutions Matter? Government Capabilities in the United States and Abroad." Washington DC: The Brookings Institution, 1993.

Wilson, James Q. The Politics of Regulation. New York: Basic Books, 1980.

Wilson, Reid. "Initiative spending booms past \$1B as corporations sponsor their own proposals." GovBeat. Washington Post website. Published November $8^{\text {th }}, 2013$. Accessed online.

<http://www.washingtonpost.com/blogs/govbeat/wp/2013/11/08/initiativespending-booms-past-1-billion-as-corporations-sponsor-their-own-proposals/>

Zaller, John. The Nature and Origins of Mass Opinion. Cambridge: Cambridge University Press. 1992.

Zisk, Betty. Money, Media, and the Grass Roots. Newbury Park: Sage, 1987. 


\section{- Appendix A - Design \#1 Data}

Below, in Table A.1, the data is presented for every poll under Design \#1. Columns are provided corresponding to initiative number, state, and year, the name of the surveyor who conducted the poll, the date and size of the sample, the percentage who responded Yes, No, and "Don't Know," and the competitive dynamic type number assigned to the poll. For a small portion of the polls, data on sample size were not available. 


\begin{tabular}{|c|c|c|c|c|c|c|c|}
\hline INITIATIVE & SURVEY & DATES & $\begin{array}{c}\text { SAMPLE } \\
\text { SIZE }\end{array}$ & $\begin{array}{c}\text { YES } \\
\% \\
\end{array}$ & $\begin{array}{l}\text { NO } \\
\% \\
\end{array}$ & $\begin{array}{c}\text { DON'T } \\
\text { KNOW } \\
\% \\
\end{array}$ & TYPE \\
\hline 30/CA/2012 & $\begin{array}{l}\text { GQR for USC Dornsife and } \\
\text { LA Times }\end{array}$ & $\begin{array}{l}\text { March 13-19, } \\
\text { '12 }\end{array}$ & 1500 & 64 & 33 & 3 & 1 \\
\hline $30 / C A / 2012$ & PPIC & April 3-10, '12 & 823 & 54 & 39 & 7 & 1 \\
\hline $30 / C A / 2012$ & PPIC & May $14-20$, ' 12 & 2002 & 56 & 38 & 7 & 1 \\
\hline $30 / C A / 2012$ & Field Poll & May 21-29, '12 & 710 & 52 & 35 & 13 & 1 \\
\hline 30/CA/2012 & Field Poll & $\begin{array}{l}\text { June 21-July 2, } \\
\text { '12 }\end{array}$ & 997 & 54 & 38 & 12 & 1 \\
\hline $30 / C A / 2012$ & $\begin{array}{l}\text { PACE/USC for Rossier } \\
\text { School of Edu. }\end{array}$ & Aug. 3-7, '12 & 1041 & 55 & 36 & 9 & 1 \\
\hline $30 / C A / 2012$ & PPIC & Sept. 9-16, '12 & 2003 & 52 & 40 & 8 & 1 \\
\hline $30 / C A / 2012$ & Field Poll & Sept 17-23, '12 & 902 & 51 & 36 & 13 & 1 \\
\hline $30 / C A / 2012$ & USC Dornsife / LA Times & Sept, ' '12 & 1504 & 54 & 37 & 9 & 1 \\
\hline $30 / C A / 2012$ & Survey USA & Oct. 7-9, '12 & 700 & 33 & 38 & 29 & 3 \\
\hline $30 / C A / 2012$ & CA Business Roundtable & Oct. $7-10$, '12 & 830 & 49.5 & 41.7 & 8.8 & 3 \\
\hline $30 / C A / 2012$ & Reason-Rupe & Oct. $11-15,{ }^{\prime} 12$ & 696 & 50 & 46 & 4 & 3 \\
\hline $30 / C A / 2012$ & PPIC & Oct. $14-21,{ }^{\prime} 12$ & 2006 & 48 & 44 & 8 & 3 \\
\hline $30 / C A / 2012$ & CA Business Roundtable & Oct. $21-28,{ }^{\prime} 12$ & 2115 & 49.2 & 42.9 & 7.8 & 3 \\
\hline $30 / C A / 2012$ & Field Poll & Oct. $17-30$, ' 12 & 1912 & 48 & 38 & 14 & 2 \\
\hline $31 / C A / 2012$ & PPIC & Sept. 9-16, '12 & 2003 & 25 & 42 & 32 & 5 \\
\hline $31 / C A / 2012$ & CA Business Roundtable & Oct. $7-10,{ }^{\prime} 12$ & 830 & 57.6 & 35.5 & 26.9 & 1 \\
\hline $31 / C A / 2012$ & PPIC & Oct. $14-21,{ }^{\prime} 12$ & 2006 & 24 & 48 & 28 & 5 \\
\hline $31 / C A / 2012$ & CA Business Roundtable & Oct. $21-28$, '12 & 2115 & 37.8 & 36.8 & 25.5 & 3 \\
\hline $32 / C A / 2012$ & PPIC & Sept. 9-16, '12 & 2003 & 42 & 49 & 9 & 3 \\
\hline $32 / C A / 2012$ & Field Poll & Sept. 6-18, '12 & 1183 & 38 & 44 & 18 & 3 \\
\hline $32 / C A / 2012$ & USC Dornsife / LA Times & Sept 17-23, '12 & 1504 & 36 & 44 & 20 & 3 \\
\hline $32 / \mathrm{CA} / 2012$ & CA Business Roundtable & Oct. 7-10, '12 & 830 & 51.4 & 38.3 & 10.3 & 1 \\
\hline $32 / C A / 2012$ & Reason-Rupe & Oct. $11-15,{ }^{\prime} 12$ & 696 & 45 & 48 & 7 & 3 \\
\hline $32 / C A / 2012$ & PPIC & Oct. $14-21,{ }^{\prime} 12$ & 2006 & 39 & 53 & 7 & 4 \\
\hline $32 / C A / 2012$ & CA Business Roundtable & Oct. $21-28, ' 12$ & 2115 & 44.7 & 44.8 & 10.5 & 3 \\
\hline $32 / C A / 2012$ & Field Poll & Oct. $17-30$, ' 12 & 1912 & 34 & 50 & 16 & 5 \\
\hline $33 / C A / 2012$ & PPIC & Sept. 9-16, '12 & 2003 & 25 & 42 & 32 & 5 \\
\hline $33 / C A / 2012$ & CA Business Roundtable & Oct. $7-10,{ }^{\prime} 12$ & 830 & 37.6 & 35.5 & 26.9 & 3 \\
\hline $33 / C A / 2012$ & PPIC & Oct. $14-21$, '12 & 2006 & 24 & 48 & 28 & 5 \\
\hline $33 / C A / 2012$ & CA Business Roundtable & Oct. $21-28, ' 12$ & 2115 & 37.8 & 36.8 & 25.5 & 3 \\
\hline $34 / C A / 2012$ & USC Dornsife / LA Times & Sept. 17-23, '12 & 1503 & 38 & 51 & 11 & 4 \\
\hline $34 / C A / 2012$ & Survey USA & Oct. 7-9, '12 & 700 & 32 & 48 & 20 & 5 \\
\hline $34 / C A / 2012$ & CA Business Roundtable & Oct. $7-10,{ }^{\prime} 12$ & 830 & 42.9 & 48.1 & 9 & 3 \\
\hline $34 / C A / 2012$ & USC Dornsife / LA Times & Oct. $15-21$, '12 & 1504 & 42 & 45 & 13 & 3 \\
\hline $34 / C A / 2012$ & CA Business Roundtable & Oct. $21-28, ' 12$ & 2115 & 41.3 & 47.9 & 10.8 & 3 \\
\hline 34/CA/2012 & Field Poll & Oct. 17-30, '12 & 1912 & 45 & 38 & 17 & 3 \\
\hline
\end{tabular}

Table A.1: Raw opinion poll data with competitive dynamic typing 
Table A.1: Raw opinion poll data with competitive dynamic typing (continued)

\begin{tabular}{|c|c|c|c|c|c|c|c|}
\hline INITIATIVE & SURVEY & DATES & $\begin{array}{c}\text { SAMPLE } \\
\text { SIZE }\end{array}$ & $\begin{array}{c}\text { YES } \\
\% \\
\end{array}$ & $\begin{array}{l}\text { NO } \\
\% \\
\end{array}$ & $\begin{array}{c}\text { DON'T } \\
\text { KNOW } \\
\%\end{array}$ & TYPE \\
\hline $35 / C A / 2012$ & CA Business Roundtable & Oct. 7-10, '12 & 830 & 77.8 & 13.6 & 8.6 & 1 \\
\hline $35 / C A / 2012$ & CA Business Roundtable & Oct. $21-28$, '12 & 2115 & 76.5 & 13.7 & 9.8 & 1 \\
\hline $36 / C A / 2012$ & USC Dornsife / LA Times & Sept. 17-23, '12 & 1504 & 66 & 20 & 14 & 1 \\
\hline $36 / C A / 2012$ & Survey USA & Oct. 7-9, '12 & 700 & 44 & 22 & 34 & 1 \\
\hline $36 / C A / 2012$ & CA Business Roundtable & Oct. 7-10, '12 & 830 & 72 & 17.1 & 10.9 & 1 \\
\hline $36 / C A / 2012$ & USC Dornsife / LA Times & Oct. $15-21$, '12 & 1504 & 63 & 22 & 15 & 1 \\
\hline $36 / C A / 2012$ & CA Business Roundtable & Oct. $21-28,{ }^{\prime} 12$ & 2115 & 67.4 & 22 & 10.6 & 1 \\
\hline $37 / C A / 2012$ & USC Dornsife / LA Times & Sept. 17-23, '12 & 1504 & 61 & 25 & 14 & 1 \\
\hline $37 / C A / 2012$ & Survey USA & Oct. 7-9, '12 & 700 & 39 & 30 & 31 & 3 \\
\hline $37 / C A / 2012$ & CA Business Roundtable & Oct. 7-10, '12 & 830 & 48.3 & 40.2 & 11.5 & 3 \\
\hline $37 / C A / 2012$ & CA Business Roundtable & Oct. $21-28$, '12 & 2115 & 39.1 & 50.5 & 10.5 & 5 \\
\hline $38 / C A / 2012$ & Field Poll & Feb. 14-28, '12 & 344 & 45 & 48 & 7 & 3 \\
\hline $38 / C A / 2012$ & $\begin{array}{l}\text { GQR for USC Dornsife } \\
\text { and LA Times }\end{array}$ & Mar. 14-19, '12 & 1500 & 32 & 64 & 4 & 5 \\
\hline $38 / \mathrm{CA} / 2012$ & Field Poll & May $21-29$, '12 & 710 & 42 & 43 & 15 & 3 \\
\hline $38 / \mathrm{CA} / 2012$ & Field Poll & $6 / 21-7 / 2, ' 12$ & 997 & 46 & 46 & 8 & 3 \\
\hline $38 / C A / 2012$ & $\begin{array}{l}\text { PACE/USC for Rossier } \\
\text { School of Edu. }\end{array}$ & Aug. 3-7, '12 & 1041 & 40 & 49 & 11 & 4 \\
\hline $38 / C A / 2012$ & PPIC & Sept. 9-16, '12 & 2003 & 45 & 45 & 11 & 3 \\
\hline $38 / \mathrm{CA} / 2012$ & Field Poll & Sept. 6-18, '12 & 902 & 41 & 44 & 15 & 3 \\
\hline $38 / C A / 2012$ & USC Dornsife / LA Times & Sept. 17-23, '12 & 1504 & 34 & 52 & 14 & 5 \\
\hline $38 / C A / 2012$ & CA Business Roundtable & Oct. 7-10, '12 & 830 & 41.9 & 45.9 & 12.2 & 3 \\
\hline $38 / C A / 2012$ & Reason-Rupe & Oct. $11-15$, ' 12 & 696 & 42 & 52 & 6 & 5 \\
\hline $38 / \mathrm{CA} / 2012$ & PPIC & Oct. $14-21$, '12 & 2006 & 39 & 53 & 8 & 5 \\
\hline $38 / C A / 2012$ & CA Business Roundtable & Oct. $17-30$, '12 & 2115 & 33 & 54.1 & 12.8 & 5 \\
\hline $38 / C A / 2012$ & Field Poll & $6 / 21-7 / 2, ' 12$ & 1912 & 34 & 49 & 17 & 5 \\
\hline $39 / C A / 2012$ & Field Poll & $6 / 21-7 / 2,{ }^{\prime} 12$ & 997 & 44 & 43 & 13 & 3 \\
\hline $39 / \mathrm{CA} / 2012$ & Field Poll & Sept. 6-18, '12 & 902 & 45 & 39 & 16 & 3 \\
\hline $39 / C A / 2012$ & USC Dornsife / LA Times & Sept. 17-23, '12 & 1504 & 51 & 29 & 20 & 1 \\
\hline $39 / C A / 2012$ & CA Business Roundtable & Oct. 7-10, '12 & 830 & 60.6 & 25.1 & 14.3 & 1 \\
\hline $39 / C A / 2012$ & CA Business Roundtable & Oct. $21-28$, '12 & 2115 & 54.5 & 28.5 & 17 & 1 \\
\hline $80 / O R / 2012$ & Survey USA & Sept. 10-13, '12 & 700 & 37 & 41 & 22 & 3 \\
\hline $80 / O R / 2012$ & Survey USA & Oct. $16-18$, '12 & 700 & 36 & 43 & 21 & 3 \\
\hline $80 / O R / 2012$ & Elway & Oct. $25-28, ' 12$ & 405 & 42 & 49 & 9 & 4 \\
\hline $82 / O R / 2012$ & Survey USA & Sept. 10-13, '12 & 700 & 27 & 43 & 31 & 5 \\
\hline $82 / O R / 2012$ & Survey USA & Oct. $16-18$, '12 & 700 & 28 & 53 & 19 & 5 \\
\hline $82 / O R / 2012$ & $\begin{array}{l}\text { Elway Research for The } \\
\text { Oregonian }\end{array}$ & Oct. $25-28, ' 12$ & 405 & 28 & 66 & 6 & 5 \\
\hline $83 / O R / 2012$ & Survey USA & Sept. 10-13, '12 & 700 & 28 & 39 & 33 & 4 \\
\hline $83 / O R / 2012$ & Survey USA & Oct. $16-18$, '12 & 700 & 26 & 54 & 20 & 5 \\
\hline
\end{tabular}


Table A.1: Raw opinion poll data with competitive dynamic typing (continued)

\begin{tabular}{|c|c|c|c|c|c|c|c|}
\hline INITIATIVE & SURVEY & DATES & $\begin{array}{c}\text { SAMPLE } \\
\text { SIZE }\end{array}$ & $\begin{array}{c}\text { YES } \\
\% \\
\end{array}$ & $\begin{array}{l}\text { NO } \\
\% \\
\end{array}$ & $\begin{array}{c}\text { DON'T } \\
\text { KNOW } \\
\% \\
\end{array}$ & TYPE \\
\hline $83 / O R / 2012$ & Elway & Oct. $25-28, ' 12$ & 405 & 26 & 66 & 8 & 5 \\
\hline $85 / O R / 2012$ & Survey USA & Sept. 10-13, '12 & 700 & 14 & 21 & 65 & 3 \\
\hline 85/OR/2012 & Survey USA & Oct. $16-18$, ' $^{12}$ & 700 & 53 & 26 & 21 & 1 \\
\hline $85 / O R / 2012$ & Elway & Oct. $25-28, ' 12$ & 405 & 52 & 33 & 14 & 1 \\
\hline 502/WA/2012 & Elway Research & July ' 11 & 408 & 54 & 43 & 3 & 1 \\
\hline 502/WA/2012 & Elway Research & Jan. '12 & 411 & 48 & 45 & 7 & 3 \\
\hline 502/WA/2012 & Survey USA & July $16-17$, '12 & 630 & 55 & 32 & 13 & 1 \\
\hline 502/WA/2012 & PPP & Nov. 1-3, '12 & 932 & 53 & 44 & 3 & 1 \\
\hline 19/CA/2010 & Survey USA & April 20, '10 & 500 & 56 & 42 & 3 & 1 \\
\hline 19/CA/2010 & PPIC & May 9-16, '10 & 2003 & 49 & 48 & 3 & 3 \\
\hline 19/CA/2010 & Field Poll & $6 / 22-7 / 5, ' 10$ & 1005 & 44 & 48 & 8 & 3 \\
\hline 19/CA/2010 & PPP & July $23-25$, '10 & 614 & 52 & 36 & 12 & 1 \\
\hline 19/CA/2010 & Survey USA & July 8-11, '10 & 614 & 50 & 40 & 11 & 1 \\
\hline 19/CA/2010 & Survey USA & 8/21-9/1, '10 & 569 & 47 & 43 & 10 & 3 \\
\hline 19/CA/2010 & Field Poll & Sept. $14-21,{ }^{\prime} 10$ & 599 & 49 & 42 & 9 & 2 \\
\hline 19/CA/2010 & Survey USA & Sept 19-21, '10 & 610 & 47 & 42 & 11 & 3 \\
\hline 19/CA/2010 & PPIC & Sept 19-26, '10 & 2004 & 52 & 41 & 7 & 1 \\
\hline 19/CA/2010 & Reuters/Ipsos & Oct. 2-4, '10 & 448 & 43 & 53 & 3 & 5 \\
\hline 19/CA/2010 & PPIC & Oct. $10-17,{ }^{\prime} 10$ & 2002 & 44 & 49 & 7 & 3 \\
\hline 19/CA/2010 & $\begin{array}{l}\text { GQR for USC Dornsife } \\
\text { and LA Times }\end{array}$ & Oct. $13-20,{ }^{\prime} 10$ & 922 & 39 & 51 & 10 & 5 \\
\hline 19/CA/2010 & Field for Sac. Bee & Oct. $14-26$, '10 & 1501 & 42 & 49 & 9 & 3 \\
\hline 23/CA/2010 & Field Poll & $6 / 22-7 / 5, ' 10$ & 1005 & 36 & 48 & 16 & 4 \\
\hline 23/CA/2010 & GQR for AV & Sept. $15-22,{ }^{\prime} 10$ & 1511 & 40 & 38 & 22 & 3 \\
\hline 23/CA/2010 & Field Poll & Sept. 14-21, '10 & 599 & 34 & 45 & 11 & 4 \\
\hline 23/CA/2010 & PPIC & Sept. 19-26, '10 & 2004 & 43 & 42 & 15 & 3 \\
\hline $23 / C A / 2010$ & Reuters/Ipsos & Oct. $2-4$, '10 & 600 & 37 & 49 & 14 & 4 \\
\hline 23/CA/2010 & PPIC & Oct. $10-17,{ }^{\prime} 10$ & 2002 & 37 & 48 & 15 & 4 \\
\hline 23/CA/2010 & Field for Sac. Bee & Oct. $14-26, ' 10$ & 1501 & 33 & 48 & 19 & 5 \\
\hline 24/CA/2010 & PPIP & Sept. 19-26, '10 & 2004 & 35 & 35 & 30 & 3 \\
\hline $24 / C A / 2010$ & PPIP & Oct. $10-17,{ }^{\prime} 10$ & 2002 & 31 & 38 & 31 & 3 \\
\hline 25/CA/2010 & Field Poll & $6 / 22-7 / 5, ' 10$ & 1005 & 65 & 20 & 15 & 1 \\
\hline 25/CA/2010 & Field Poll & Sept. 14-21, '10 & 599 & 46 & 30 & 24 & 1 \\
\hline 25/CA/2010 & PPIC & Sept. 19-26, '10 & 2004 & 48 & 35 & 17 & 2 \\
\hline 25/CA/2010 & Reuters/Ipsos & Oct. 2-4, '10 & 600 & 58 & 29 & 13 & 1 \\
\hline 25/CA/2010 & PPIC & Oct. $10-17,{ }^{\prime} 10$ & 2002 & 49 & 34 & 17 & 1 \\
\hline $25 / C A / 2010$ & Field for Sac. Bee & Oct. $14-26$, '10 & 1501 & 48 & 31 & 21 & 1 \\
\hline 73/OR/2010 & Grove Insight & Aug. 18-21, '10 & 600 & 62 & 21 & 16 & 1 \\
\hline
\end{tabular}


Table A.1: Raw opinion poll data with competitive dynamic typing (continued)

\begin{tabular}{|c|c|c|c|c|c|c|c|}
\hline INITIATIVE & SURVEY & DATES & $\begin{array}{c}\text { SAMPLE } \\
\text { SIZE }\end{array}$ & $\begin{array}{c}\text { YES } \\
\%\end{array}$ & $\begin{array}{l}\text { NO } \\
\%\end{array}$ & $\begin{array}{c}\text { DON'T } \\
\text { KNOW } \\
\%\end{array}$ & TYPE \\
\hline $73 / O R / 2010$ & Elway & Oct. 18-19, '10 & 500 & 60 & I & l & 1 \\
\hline $74 / O R / 2010$ & Grove Insight & Aug. 18-21, '10 & 600 & 41 & 46 & 13 & 3 \\
\hline $74 / O R / 2010$ & Elway & Oct. $18-19$, '10 & 500 & 40 & I & I & 5 \\
\hline $75 / O R / 2010$ & Grove Insight & Aug. 18-21, '10 & 600 & 35 & 51 & 14 & 5 \\
\hline $75 / O R / 2010$ & Elway Research & Oct. $18-19$, '10 & 500 & 33 & 54 & 13 & 5 \\
\hline 76/OR/2010 & $\begin{array}{l}\text { Elway Research for } \\
\text { The Oregonian }\end{array}$ & Oct. $18-19$, '10 & 500 & 60 & 23 & 17 & 1 \\
\hline 1053/WA/2010 & Washington Poll & May $23-30,{ }^{\prime} 10$ & 1252 & 60 & 24 & 16 & 1 \\
\hline 1053/WA/2010 & Survey USA & Aug. 26-29, '10 & 650 & 55 & 18 & 26 & 1 \\
\hline 1053/WA/2010 & Survey USA & 9/30-10/3, '10 & 639 & 56 & 19 & 25 & 1 \\
\hline 1053/WA/2010 & Elway Research & Oct. 7-10, '10 & 400 & 49 & 34 & 17 & 1 \\
\hline 1053/WA/2010 & Elway Research & Sept. 9-12, '10 & 500 & 48 & 27 & 25 & 1 \\
\hline 1082/WA/2010 & Survey USA & Sept. 9-12, '10 & 500 & 31 & 31 & 38 & 3 \\
\hline 1082/WA/2010 & Elway Research & Oct. $7-10$, '10 & 400 & 31 & 40 & 29 & 3 \\
\hline 1098/WA/2010 & Survey USA & April 21, '10 & 500 & 66 & 27 & 6 & 1 \\
\hline 1098/WA/2010 & Washington Poll & May 3-23, '10 & 1252 & 58 & 30 & 10 & 1 \\
\hline 1098/WA/2010 & Elway Research & June 9-13, '10 & 405 & 46 & 46 & 8 & 3 \\
\hline 1098/WA/2010 & PPP & $7 / 27-8 / 1, ' 10$ & 1204 & 41 & 41 & 18 & 3 \\
\hline 1098/WA/2010 & Survey USA & Aug. 26-29, '10 & 650 & 41 & 33 & 26 & 3 \\
\hline 1098/WA/2010 & Elway Research & Sept. 9-12, '10 & 500 & 44 & 42 & 14 & 3 \\
\hline 1098/WA/2010 & Survey USA & 9/30-10/3, '10 & 639 & 41 & 39 & 20 & 3 \\
\hline 1098/WA/2010 & Elway & Oct. 7-10, '10 & 400 & 41 & 48 & 11 & 3 \\
\hline 1098/WA/2010 & Washington Poll & $10 / 5-14+18-28$ & 695 & 43 & 54 & 3 & 5 \\
\hline 1098/WA/2010 & Survey USA & Oct. $24-27$, '10 & 504 & 34 & 56 & 10 & 5 \\
\hline 1100/WA/2010 & Washington Poll & May 3-23, '10 & 1252 & 52 & 37 & 8 & 1 \\
\hline 1100/WA/2010 & Elway Research & Sept. 9-12, '10 & 500 & 45 & 34 & 21 & 2 \\
\hline 1100/WA/2010 & Elway Research & Oct. 7-10, '10 & 400 & 42 & 44 & 14 & 3 \\
\hline 1100/WA/2010 & Washington Poll & Oct. $4-14$, '10 & 500 & 47 & 49 & 1 & 3 \\
\hline 1100/WA/2010 & Survey USA & Oct. $24-27, ' 10$ & 504 & 48 & 40 & 12 & 3 \\
\hline 1105/WA/2010 & Elway Research & Sept. 9-12, '10 & 500 & 41 & 33 & 26 & 3 \\
\hline 1105/WA/2010 & Elway Research & Oct. 7-10, '10 & 400 & 36 & 45 & 18 & 3 \\
\hline 1107/WA/2010 & Survey USA & Aug. 26-29, '10 & 650 & 42 & 34 & 24 & 3 \\
\hline 1107/WA/2010 & Elway Research & Sept. 9-12, '10 & 500 & 47 & 38 & 15 & 3 \\
\hline $1107 / W A / 2010$ & Survey USA & 9/30-10/3, '10 & 639 & 52 & 29 & 19 & 1 \\
\hline 1107/WA/2010 & Elway Research & Oct. $7-10,{ }^{\prime} 10$ & 400 & 54 & 33 & 13 & 1 \\
\hline 1107/WA/2010 & Washington Poll & Oct. $4-14,{ }^{\prime} 10$ & 500 & 56 & 36 & 7 & 1 \\
\hline 1107/WA/2010 & Survey USA & Oct. $24-27, ' 10$ & 504 & 56 & 36 & 9 & 1 \\
\hline $2 / C A / 2008$ & Field Poll & July 22, '08 & I & 63 & 24 & 13 & 1 \\
\hline
\end{tabular}


Table A.1: Raw opinion poll data with competitive dynamic typing (continued)

\begin{tabular}{|c|c|c|c|c|c|c|c|}
\hline INITIATIVE & SURVEY & DATES & $\begin{array}{c}\text { SAMPLE } \\
\text { SIZE }\end{array}$ & $\begin{array}{c}\text { YES } \\
\% \\
\end{array}$ & $\begin{array}{c}\text { NO } \\
\% \\
\end{array}$ & $\begin{array}{c}\text { DON'T } \\
\text { KNOW } \\
\% \\
\end{array}$ & TYPE \\
\hline $2 / \mathrm{CA} / 2008$ & Field Poll & Oct. $18-28$, '08 & 966 & 60 & 27 & 13 & 1 \\
\hline $3 / \mathrm{CA} / 2008$ & Field Poll & Sept. '08 & / & 47 & 35 & 18 & 2 \\
\hline $4 / C A / 2008$ & Field Poll & July 22, '08 & I & 48 & 39 & 13 & 3 \\
\hline $4 / C A / 2008$ & PPIC & Aug. 8, '08 & 2004 & 47 & 44 & 9 & 3 \\
\hline 4/CA/2008 & PPIC & Sept. 8, '08 & 2004 & 48 & 45 & 7 & 3 \\
\hline $4 / C A / 2008$ & PPIC & Oct. 8, '08 & 2004 & 45 & 45 & 10 & 3 \\
\hline $4 / C A / 2008$ & Survey USA & Oct. $15-16$, '08 & 800 & 43 & 35 & 22 & 3 \\
\hline 4/CA/2008 & PPIC & Oct. $12-19$, '08 & I & 46 & 44 & 10 & 3 \\
\hline $7 / C A / 2008$ & Field Poll & July 22, '08 & I & 63 & 24 & 13 & 1 \\
\hline $7 / C A / 2008$ & Field Poll & Oct. $18-28$, '08 & 966 & 39 & 43 & 18 & 3 \\
\hline $8 / C A / 2008$ & PPIC & Aug. 8, '08 & 2004 & 40 & 52 & 8 & 5 \\
\hline $8 / C A / 2008$ & PPIC & Sept. 8, '08 & 2004 & 41 & 51 & 8 & 5 \\
\hline $8 / C A / 2008$ & PPIC & Oct. 8, '08 & 2004 & 44 & 48 & 12 & 3 \\
\hline $8 / C A / 2008$ & Field Poll & Oct. $18-28,{ }^{\prime} 08$ & 966 & 44 & 49 & 7 & 3 \\
\hline $10 / \mathrm{CA} / 2008$ & Field Poll & Oct. '08 & I & 49 & 39 & 12 & 2 \\
\hline 11/CA/2008 & Field Poll & July 22, '08 & l & 42 & 30 & 28 & 2 \\
\hline $11 / \mathrm{CA} / 2008$ & Field Poll & Oct. $18-28$, '08 & 966 & 45 & 30 & 25 & 1 \\
\hline 985/WA/2008 & Survey USA & Sept. 5-7, '08 & 900 & 16 & 14 & 70 & 3 \\
\hline 985/WA/2008 & Survey USA & Sept. 21-22, '08 & 900 & 20 & 13 & 67 & 3 \\
\hline 985/WA/2008 & Washington Poll & Oct. '08 & / & 45 & 43 & 12 & 3 \\
\hline 985/WA/2008 & Survey USA & $10 / 30-11 / 2,{ }^{\prime} 08$ & 800 & 33 & 45 & 23 & 4 \\
\hline 1000/WA/2008 & Survey USA & Sept. 5-7, '08 & 900 & 52 & 25 & 23 & 1 \\
\hline 1000/WA/2008 & Survey USA & Sept. 21-22, '08 & 900 & 54 & 26 & 20 & 1 \\
\hline 1000/WA/2008 & Survey USA & Oct. $12-13$, '08 & 1000 & 49 & 32 & 19 & 1 \\
\hline 1000/WA/2008 & Survey USA & $10 / 30-11 / 2,{ }^{\prime} 08$ & 800 & 55 & 40 & 5 & 1 \\
\hline 1029/WA/2008 & Washington Poll & Oct. '08 & I & 65 & 20 & 15 & 1 \\
\hline $85 / C A / 2006$ & Field Poll & Late Oct. '06 & I & 46 & 43 & 11 & 3 \\
\hline $85 / C A / 2006$ & Field Poll & July '06 & I & 44 & 45 & 11 & 3 \\
\hline $86 / \mathrm{CA} / 2006$ & Field Poll & Late Oct. '06 & I & 45 & 45 & 10 & 3 \\
\hline $86 / C A / 2006$ & Field Poll & Late Sept. '06 & I & 53 & 40 & 7 & 1 \\
\hline $86 / C A / 2006$ & Field Poll & July '06 & I & 63 & 32 & 5 & 1 \\
\hline $87 / C A / 2006$ & Field Poll & Late Oct. '06 & I & 40 & 44 & 16 & 3 \\
\hline $87 / C A / 2006$ & Field Poll & Late Sept. '06 & I & 44 & 41 & 15 & 3 \\
\hline $87 / C A / 2006$ & Field Poll & July '06 & I & 52 & 31 & 17 & 1 \\
\hline $90 / C A / 2006$ & Field Poll & Late Oct. '06 & I & 35 & 42 & 23 & 3 \\
\hline $90 / C A / 2006$ & Field Poll & July '06 & I & 46 & 31 & 23 & 1 \\
\hline $61 / \mathrm{CA} / 2004$ & Field Poll & Late Oct. '04 & l & 54 & 29 & 17 & 1 \\
\hline $61 / \mathrm{CA} / 2004$ & Field Poll & Sept. '04 & I & 47 & 31 & 22 & 1 \\
\hline $61 / \mathrm{CA} / 2004$ & Field Poll & Late Sept. '04 & I & 46 & 35 & 19 & 2 \\
\hline $62 / C A / 2004$ & Field Poll & May'04 & I & 50 & 37 & 13 & 1 \\
\hline
\end{tabular}


Table A.1: Raw opinion poll data with competitive dynamic typing (continued)

\begin{tabular}{|c|c|c|c|c|c|c|c|}
\hline INITIATIVE & SURVEY & DATES & $\begin{array}{c}\text { SAMPLE } \\
\text { SIZE }\end{array}$ & $\begin{array}{c}\text { YES } \\
\% \\
\end{array}$ & $\begin{array}{l}\text { NO } \\
\% \\
\end{array}$ & $\begin{array}{c}\text { DON'T } \\
\text { KNOW } \\
\% \\
\end{array}$ & TYPE \\
\hline $62 / C A / 2004$ & Field Poll & Late Oct. '04 & I & 40 & 38 & 22 & 3 \\
\hline 64/CA/2004 & Field Poll & Aug. '04 & / & 21 & 41 & 38 & 5 \\
\hline 64/CA/2004 & Field Poll & Late Sept. '04 & / & 26 & 38 & 36 & 4 \\
\hline 64/CA/2004 & Field Poll & Late Oct. '04 & I & 32 & 37 & 31 & 3 \\
\hline $66 / C A / 2004$ & Field Poll & May '04 & I & 76 & 14 & 10 & 1 \\
\hline $66 / C A / 2004$ & Field Poll & Aug. '04 & I & 69 & 19 & 12 & 1 \\
\hline $66 / C A / 2004$ & Field Poll & Early Oct. '04 & I & 65 & 18 & 17 & 1 \\
\hline $66 / C A / 2004$ & Field Poll & Oct. 21-24, '04 & I & 58 & 34 & 8 & 1 \\
\hline $66 / C A / 2004$ & Field Poll & Oct. 25-27, '04 & 1 & 46 & 47 & 7 & 3 \\
\hline $67 / C A / 2004$ & Field Poll & Aug. '04 & 1 & 37 & 47 & 16 & 4 \\
\hline 67/CA/2004 & Field Poll & Late Sept. '04 & I & 37 & 46 & 17 & 3 \\
\hline $67 / C A / 2004$ & Field Poll & Late Oct. '04 & I & 37 & 50 & 13 & 5 \\
\hline 71/CA/2004 & Field Poll & July '04 & I & 45 & 42 & 13 & 3 \\
\hline 71/CA/2004 & Field Poll & Late Sept. '04 & 1 & 46 & 39 & 15 & 3 \\
\hline 71/CA/2004 & Field Poll & Late Oct. '04 & I & 54 & 37 & 9 & 1 \\
\hline $62 / C A / 2004$ & Field Poll & Aug. '04 & I & 44 & 31 & 25 & 2 \\
\hline 62/CA/2004 & Field Poll & Early Oct. '04 & / & 44 & 31 & 25 & 2 \\
\hline
\end{tabular}

Below, in Table A.2, the initiative contests in the sample are shown alongside their median polling type, Yes and No spending strength and aggregate spending (in thousands of dollars), and Yes vote share values. 


\begin{tabular}{|c|c|c|c|c|c|c|}
\hline INITIATIVE & $\begin{array}{c}\text { MEDIAN } \\
\text { POLL } \\
\text { TYPE } \\
\end{array}$ & $\begin{array}{l}\text { YES SPENDING } \\
\text { (\$ thousands) }\end{array}$ & $\begin{array}{l}\text { NO SPENDING } \\
\text { (\$ thousands) }\end{array}$ & $\begin{array}{c}\text { YES } \\
\text { SPENDING } \\
\text { STRENGTH }\end{array}$ & $\begin{array}{c}\text { NO } \\
\text { SPENDING } \\
\text { STRENGTH }\end{array}$ & $\begin{array}{c}\text { YES } \\
\text { VOTE } \\
\%\end{array}$ \\
\hline $30 / C A / 2012$ & 1 & 53561 & 49280 & 3.27 & 2.94 & 55.4 \\
\hline $31 / C A / 2012$ & 4 & 5868 & 331 & 0.36 & 0.02 & 39.5 \\
\hline $32 / \mathrm{CA} / 2012$ & 3 & 3 & 45568 & 72121 & 2.78 & 43.4 \\
\hline $33 / \mathrm{CA} / 2012$ & 4 & 14900 & 269 & 0.91 & 0.01 & 45 \\
\hline $34 / C A / 2012$ & 3 & 393 & 6934 & 0.02 & 0.41 & 48 \\
\hline $35 / C A / 2012$ & 1 & 2969 & 0 & 0.18 & 0 & 81.3 \\
\hline $36 / C A / 2012$ & 1 & 2397 & 120 & 0.15 & 0 & 69.3 \\
\hline $37 / C A / 2012$ & 3 & 9477 & 44109 & 0.58 & 2.63 & 48.6 \\
\hline $38 / C A / 2012$ & 3 & 14558 & 40 & 0.89 & 0 & 28.7 \\
\hline 39/CA/2012 & 1 & 32126 & 44 & 1.96 & 0 & 61.1 \\
\hline $80 / O R / 2012$ & 3 & 50 & 4 & 0 & 0.4 & 46.6 \\
\hline $82 / O R / 2012$ & 5 & 2878 & 1354 & 2.91 & 2.43 & 28.3 \\
\hline $83 / O R / 2012$ & 5 & 2878 & 1354 & 2.91 & 2.43 & 29.2 \\
\hline $85 / O R / 2012$ & 1 & 1235 & 70 & 0.15 & 1.05 & 59.9 \\
\hline 502/WA/2012 & 1 & 6171 & 16 & 1.24 & 0.01 & 55.7 \\
\hline 19/CA/2010 & 3 & 3398 & 423 & 0.21 & 0.03 & 46.5 \\
\hline 23/CA/2010 & 4 & 10467 & 35251 & 0.63 & 2.1 & 38.4 \\
\hline $24 / C A / 2010$ & 3 & 14583 & 15488 & 0.89 & 0.92 & 41.9 \\
\hline 25/CA/2010 & 1 & 17908 & 9635 & 1.09 & 0.57 & 55.1 \\
\hline 73/OR/2010 & 1 & 7 & 368 & 0.79 & 0 & 56.9 \\
\hline 74/OR/2010 & 4 & 144 & 3 & 0 & 0.12 & 44.2 \\
\hline 75/OR/2010 & 5 & 674 & 564 & 1.21 & 0.57 & 31.8 \\
\hline 76/OR/2010 & 1 & 1581 & 3 & 0 & 1.34 & 69.2 \\
\hline 1053/WA/2010 & 1 & 1505 & 1639 & 0.3 & 0.64 & 63.8 \\
\hline 1082/WA/2010 & 3 & 3431 & 6019 & 0.69 & 2.37 & 40.9 \\
\hline 1098/WA/2010 & 3 & 6423 & 6370 & 1.29 & 2.47 & 35.9 \\
\hline $1100 / \mathrm{WA} / 2010$ & 3 & 6063 & 9170 & 1.22 & 3.56 & 46.6 \\
\hline $1105 / \mathrm{WA} / 2010$ & 3 & 2744 & 0 & 0.55 & 0 & 35 \\
\hline $1107 / \mathrm{WA} / 2010$ & 1 & 16043 & 427 & 3.22 & 0.17 & 39.6 \\
\hline
\end{tabular}

Table A.2: Initiative contest Yes and No campaign spending strength and vote share 
Table A.2: Initiative contest Yes and No campaign spending strength and vote share (continued)

\begin{tabular}{|c|c|c|c|c|c|c|}
\hline INITIATIVE & $\begin{array}{c}\text { MEDIAN } \\
\text { POLL } \\
\text { TYPE } \\
\end{array}$ & $\begin{array}{l}\text { YES SPENDING } \\
\text { (\$ thousands) }\end{array}$ & $\begin{array}{l}\text { NO SPENDING } \\
\text { (\$ thousands) }\end{array}$ & $\begin{array}{c}\text { YES } \\
\text { SPENDING } \\
\text { STRENGTH }\end{array}$ & $\begin{array}{c}\text { NO } \\
\text { SPENDING } \\
\text { STRENGTH }\end{array}$ & $\begin{array}{c}\text { YES } \\
\text { VOTE } \\
\%\end{array}$ \\
\hline $2 / C A / 2008$ & 1 & 10314 & 8796 & 0.63 & 0.52 & 63.5 \\
\hline $3 / C A / 2008$ & 2 & 6893 & 0 & 0.42 & 0 & 55.4 \\
\hline $4 / C A / 2008$ & 3 & 2527 & 10325 & 0.15 & 0.62 & 48 \\
\hline $7 / \mathrm{CA} / 2008$ & 2 & 29787 & 9286 & 1.82 & 0.55 & 35.5 \\
\hline $8 / C A / 2008$ & 4 & 41707 & 63494 & 2.55 & 3.79 & 52.2 \\
\hline 10/CA/2008 & 2 & 22859 & 182 & 1.4 & 0.01 & 40.5 \\
\hline 11/CA/2008 & 2 & 16742 & 1632 & 1.02 & 0.1 & 50.9 \\
\hline 985/WA/2008 & 3 & 899 & 249 & 0.15 & 0.1 & 40 \\
\hline 1000/WA/2008 & 1 & 5538 & 1695 & 1.11 & 0.66 & 57.8 \\
\hline 1029/WA/2008 & 1 & 995 & 178 & 0.2 & 0.07 & 72.5 \\
\hline $85 / C A / 2006$ & 3 & 3797 & 6896 & 0.23 & 0.41 & 45.8 \\
\hline $86 / C A / 2006$ & 1 & 16446 & 66340 & 1.01 & 3.96 & 48.3 \\
\hline 87/CA/2006 & 3 & 61342 & 92948 & 3.75 & 5.54 & 45.5 \\
\hline $90 / C A / 2006$ & 2 & 4029 & 14345 & 0.25 & 0.86 & 47.6 \\
\hline $61 / C A / 2004$ & 1 & 4521 & 0 & 0.27 & 0 & 41.7 \\
\hline $62 / C A / 2004$ & 2 & 2464 & 499 & 0.15 & 0.03 & 46.1 \\
\hline $64 / C A / 2004$ & 4 & 19479 & 3129 & 1.19 & 0.19 & 59 \\
\hline $66 / C A / 2004$ & 1 & 5037 & 71 & 0.28 & 0.3 & 47.3 \\
\hline $67 / C A / 2004$ & 4 & 6144 & 7288 & 0.38 & 0.37 & 28.4 \\
\hline 71/CA/2004 & 3 & 25000 & 400 & 1.53 & 0.02 & 59.1 \\
\hline
\end{tabular}




\section{- Appendix B - Design \#2 Data}

Below, Table B.1 displays the data collected under Design \# 2 for the state of California. So that the Wilson typing can be evaluated by the reader, a brief description of the initiative's substance is provided. Also presented alongside each initiative contest is Yes and No spending in thousands of dollars and Yes vote share. Following Table B.1, the same sort of display is presented of the data for California initiatives in Table B.2. 


\begin{tabular}{|c|c|c|c|c|c|}
\hline INITIATIVE & $\begin{array}{l}\text { WILSON } \\
\text { TYPE }\end{array}$ & $\begin{array}{l}\text { INITIATIVE } \\
\text { SUBSTANCE }\end{array}$ & $\begin{array}{c}\text { YES } \\
\text { SPEND }\end{array}$ & $\begin{array}{c}\text { NO } \\
\text { SPEND }\end{array}$ & $\begin{array}{c}\text { YES VOTE } \\
\% \\
\end{array}$ \\
\hline $30 / C A / 2012$ & 2 & $\begin{array}{l}\text { Jerry Brown's tax increase for general fund and } \\
\text { edu. }\end{array}$ & 53561 & 49280 & 55.4 \\
\hline $31 / \mathrm{CA} / 2012$ & 4 & Two-year budget cycle & 5868 & 331 & 39.5 \\
\hline $32 / C A / 2012$ & 4 & $\begin{array}{l}\text { Ban on corporate/union contributions to } \\
\text { candidates }\end{array}$ & 3 & 45568 & 43.4 \\
\hline $33 / C A / 2012$ & 1 & Car insurance regulatory changes & 14900 & 269 & 45 \\
\hline $34 / C A / 2012$ & 4 & Ends the death penalty & 393 & 6934 & 48 \\
\hline $35 / C A / 2012$ & 4 & $\begin{array}{l}\text { Increases penalties for human trafficking/ sex } \\
\text { slavery }\end{array}$ & 2969 & 0 & 81.3 \\
\hline $36 / C A / 2012$ & 4 & Softens"Three Strikes" law & 2397 & 120 & 69.3 \\
\hline $37 / C A / 2012$ & 2 & Mandatory labelling of GMOs & 9477 & 44109 & 48.6 \\
\hline $38 / C A / 2012$ & 3 & Molly Munger's state income tax increase for edu. & 14558 & 40 & 28.7 \\
\hline $39 / C A / 2012$ & 2 & Income tax increase for multistate businesses & 32126 & 44 & 61.1 \\
\hline 19/CA/2010 & 4 & Legalizes and taxes marijuana & 3398 & 423 & 55.7 \\
\hline 23/CA/2010 & 3 & Suspends the "Global Warming Solutions Act" & 10467 & 35251 & 46.5 \\
\hline 24/CA/2010 & 2 & Eliminates three business tax breaks & 14583 & 15488 & 38.4 \\
\hline $25 / C A / 2010$ & 4 & Budget can be passed by simple majority & 17908 & 9635 & 41.9 \\
\hline $2 / \mathrm{CA} / 2008$ & 3 & Regulations on animal confinement practices & 10314 & 8796 & 63.5 \\
\hline $3 / \mathrm{CA} / 2008$ & 4 & $\$ 980$ million in bonds for children's hospitals & 6893 & 0 & 55.4 \\
\hline 4/CA/2008 & 4 & Abortion waiting period + minor parent notify & 2527 & 10325 & 48 \\
\hline $7 / C A / 2008$ & 4 & Promotes use of alternative fules & 29787 & 9286 & 35.5 \\
\hline 8/CA/2008 & 4 & Bans same-sex marriages & 41707 & 63494 & 52.2 \\
\hline $10 / C A / 2008$ & 2 & $\$ 5$ billion in bonds for renewable fuels & 22859 & 182 & 40.5 \\
\hline $11 / C A / 2008$ & 4 & $\begin{array}{l}\text { Independent commission to handle leg. } \\
\text { redistricting }\end{array}$ & 16742 & 1632 & 50.9 \\
\hline $85 / C A / 2006$ & 4 & $\begin{array}{l}\text { Require parental notification of a minor's } \\
\text { abortion }\end{array}$ & 3797 & 6896 & 50.9 \\
\hline $86 / C A / 2006$ & 2 & Tax on cigarettes & 16446 & 66340 & 48.3 \\
\hline $87 / C A / 2006$ & 2 & New tax on gas, oil & 61342 & 92948 & 45.5 \\
\hline $90 / C A / 2006$ & 3 & $\begin{array}{l}\text { Limits state's eminent domain proprty-taking } \\
\text { abilites }\end{array}$ & 4029 & 14345 & 47.6 \\
\hline $61 / \mathrm{CA} / 2004$ & 4 & $\begin{array}{l}\text { \$750 million in bonds for children's hospital } \\
\text { projects }\end{array}$ & 4521 & 0 & 41.7 \\
\hline $62 / C A / 2004$ & 4 & Elections, primaries & 2464 & 499 & 46.1 \\
\hline $64 / C A / 2004$ & 2 & $\begin{array}{l}\text { Limits on enforcement of unfair business } \\
\text { competition }\end{array}$ & 19479 & 3129 & 59 \\
\hline $66 / C A / 2004$ & 4 & "Three strikes" laws and sex crimes & 5037 & 71 & 47.3 \\
\hline $67 / C A / 2004$ & 3 & Funds emergency medical services with tax hikes & 6144 & 7288 & 28.4 \\
\hline $71 / C A / 2004$ & 2 & Spend $\$ 2$ billion on stem cell research & 25000 & 400 & 59.1 \\
\hline
\end{tabular}

Table B.1: Initiative substance, Yes and No spending strength, and Yes voting percentage of 31 California initiative contests from $2012-2000$ 


\begin{tabular}{|c|c|c|c|c|c|}
\hline INITIATIVE & $\begin{array}{c}\text { WILSON } \\
\text { TYPE }\end{array}$ & $\begin{array}{l}\text { INITIATIVE } \\
\text { SUBSTANCE }\end{array}$ & $\begin{array}{c}\text { YES } \\
\text { SPEND }\end{array}$ & $\begin{array}{c}\text { NO } \\
\text { SPEND } \\
\end{array}$ & $\begin{array}{c}\text { YES } \\
\text { VOTE } \\
\% \\
\end{array}$ \\
\hline 79/OR/2012 & 3 & bans real estate taxes & 5069.1 & 614.2 & 58.9 \\
\hline $80 / O R / 2012$ & 4 & legalize and regulate marijuana & 50.7 & 4.6 & 46.6 \\
\hline $81 / O R / 2012$ & 1 & ban gill net salmon fishing & 181.1 & 839.1 & 34.5 \\
\hline $82 / O R / 2012$ & 3 & authorizes private casinos & 2878.3 & 1354.4 & 28.3 \\
\hline $83 / O R / 2012$ & 3 & $\begin{array}{l}\text { authorizes construction of Grange } \\
\text { casino }\end{array}$ & 2878.3 & 1354.4 & 29.2 \\
\hline $84 / O R / 2012$ & 3 & phases out estate tax & 129.4 & 619.9 & 45.9 \\
\hline $85 / O R / 2012$ & 2 & creates corporate tax to fund K-12 & 1235 & 70 & 59.9 \\
\hline 73/OR/2010 & 4 & increases minimum sentences & 7.5 & 368.2 & 56.9 \\
\hline 74/OR/2010 & 4 & medical marijuana licenses & 144.4 & 3.4 & 44.2 \\
\hline 75/OR/2010 & 2 & $25 \%$ gaming tax, funds police, edu. & 674.7 & 564.3 & 31.8 \\
\hline $76 / O R / 2010$ & 4 & $\begin{array}{l}\text { \% lottery proceeds goes to } \\
\text { conservation }\end{array}$ & 1581.6 & 3.4 & 69.2 \\
\hline $58 / O R / 2008$ & 4 & requires immersion for ESL students & 180.7 & 1252.4 & 43.7 \\
\hline 59/OR/2008 & 3 & $\begin{array}{l}\text { fed. Income tax deductible on OR } \\
\text { returns }\end{array}$ & 157.9 & 1293.7 & 36.2 \\
\hline $60 / \mathrm{OR} / 2008$ & 4 & $\begin{array}{l}\text { teacher pay based on student test } \\
\text { results }\end{array}$ & 157.9 & 1258.5 & 38.6 \\
\hline $61 / \mathrm{OR} / 2008$ & 4 & establishes mandatory sentences & 572.2 & 1185.8 & 48.9 \\
\hline $62 / O R / 2008$ & 4 & $\%$ lottery proceeds goest to police & 344.1 & 1233.7 & 39.4 \\
\hline 63/OR/2008 & 3 & $\begin{array}{l}\text { less permits for property } \\
\text { improvements }\end{array}$ & 54.3 & 1708.3 & 45.8 \\
\hline $64 / O R / 2008$ & 1 & $\begin{array}{l}\text { no taxpayer funded collection of pol. } \\
\text { funds }\end{array}$ & 147.3 & 2394.8 & 49.4 \\
\hline $65 / O R / 2008$ & 4 & changes nomination process & 748 & 401.3 & 34.1 \\
\hline $33 / O R / 2004$ & 4 & allows for use of medical marijuana & 530.9 & 0 & 42.8 \\
\hline $34 / O R / 2004$ & 2 & increases state forest conservation & 1610.6 & 2825 & 29.1 \\
\hline $35 / O R / 2004$ & 1 & limits medical lawsuit liability & 11311.6 & 2692.2 & 49.2 \\
\hline $36 / O R / 2004$ & 4 & same-sex marriage ban & 2250.1 & 2954.1 & 56.6 \\
\hline $37 / O R / 2004$ & 4 & $\begin{array}{l}\text { restricts regulatory taking (see } \\
2000 \text { 's Measure } 7 \text { ) }\end{array}$ & 1084.6 & 2734.1 & 60.6 \\
\hline $38 / O R / 2004$ & 1 & $\begin{array}{l}\text { abolishes State Accident Insurance } \\
\text { Fund }\end{array}$ & 5608.3 & 4618 & 39.3 \\
\hline 21/OR/2002 & 4 & $\begin{array}{l}\text { "none of the above" judicial election } \\
\text { option }\end{array}$ & 816.3 & 141.5 & 44.1 \\
\hline
\end{tabular}

Table B.2: Initiative substance, Yes and No spending strength, and Yes voting percentage of 49 Oregon initiative contests from 2012-2000 
Table B.2: Initiative substance, Yes and No spending strength, and Yes voting percentage of 49 Oregon initiative contests from $2012-2000$

\begin{tabular}{|c|c|c|c|c|c|}
\hline INITIATIVE & $\begin{array}{l}\text { WILSON } \\
\text { TYPE }\end{array}$ & $\begin{array}{l}\text { INITIATIVE } \\
\text { SUBSTANCE }\end{array}$ & $\begin{array}{c}\text { YES } \\
\text { SPEND }\end{array}$ & $\begin{array}{c}\text { NO } \\
\text { SPEND }\end{array}$ & $\begin{array}{c}\text { YES VOTE } \\
\%\end{array}$ \\
\hline 22/OR/2002 & 4 & divides state into 7 electoral districts & 653.2 & 136.2 & 49.4 \\
\hline 23/OR/2002 & 2 & $\begin{array}{l}\text { creates universal state healthcare } \\
\text { program }\end{array}$ & 103.5 & 1305.6 & 21.5 \\
\hline 24/OR/2002 & 3 & $\begin{array}{l}\text { allows denturists to install partial } \\
\text { dentures }\end{array}$ & 40.5 & 0 & 76 \\
\hline 25/OR/2002 & 4 & increases minimum wage & 578.3 & 546.8 & 51.3 \\
\hline 26/OR/2002 & 4 & $\begin{array}{l}\text { no paying petition circulators per } \\
\text { signature }\end{array}$ & 1144.8 & 0 & 75.4 \\
\hline 27/OR/2002 & 2 & requires GMO labels on food & 1718.2 & 5396.6 & 29.5 \\
\hline 91/OR/2000 & 3 & $\begin{array}{l}\text { fed. income tax deductible on OR } \\
\text { returns }\end{array}$ & 246.1 & 1084 & 44.8 \\
\hline $92 / O R / 2000$ & 1 & $\begin{array}{l}\text { no payroll deductions for political } \\
\text { purposes }\end{array}$ & 2.9 & 2733.6 & 44.6 \\
\hline $93 / O R / 2000$ & 4 & $\begin{array}{l}\text { raising taxes, fees requires voter } \\
\text { approval }\end{array}$ & 48.9 & 995.9 & 40.2 \\
\hline $94 / O R / 2000$ & 4 & repeals mandatory minimum sentences & 163 & 170.7 & 26.5 \\
\hline 95/OR/2000 & 2 & $\begin{array}{l}\text { teacher pay based on student } \\
\text { performance }\end{array}$ & 567.8 & 1309.4 & 34.9 \\
\hline $96 / O R / 2000$ & 4 & $\begin{array}{l}\text { only direct leg. can regulate initiative } \\
\text { process }\end{array}$ & 2.2 & 34.2 & 37.8 \\
\hline $97 / O R / 2000$ & 2 & $\begin{array}{l}\text { bans certain ways of trapping, killing } \\
\text { animals }\end{array}$ & 735.4 & 796.8 & 41.2 \\
\hline $98 / O R / 2000$ & 1 & $\begin{array}{l}\text { no using public resources for political } \\
\text { causes }\end{array}$ & 3.2 & 2743.1 & 46.6 \\
\hline 99/OR/2000 & 4 & $\begin{array}{l}\text { monitors public funded homecare for } \\
\text { elderly }\end{array}$ & 142.7 & 1.4 & 62.8 \\
\hline $1 / \mathrm{OR} / 2000$ & 4 & leg. must fully fund school quality goals & 33.7 & 1.4 & 66.3 \\
\hline $2 / O R / 2000$ & 4 & process for leg. to review admin. rules & 450.9 & 960 & 43.7 \\
\hline $3 / O R / 2000$ & 4 & conviction required before forfeiture & 448.4 & 5.7 & 67.2 \\
\hline $4 / O R / 2000$ & 4 & $\begin{array}{l}\text { tobacco-settlement \$ goes to } \\
\text { healthcare }\end{array}$ & 454.6 & 156.6 & 45.2 \\
\hline $5 / O R / 2000$ & 4 & $\begin{array}{l}\text { background check before buying } \\
\text { firearm }\end{array}$ & 2028.7 & 928.6 & 61.8 \\
\hline $6 / O R / 2000$ & 4 & public funding for certain candidates & 879.9 & 287 & 41.2 \\
\hline $7 / O R / 2000$ & 4 & $\begin{array}{l}\text { gov't pays owner if regulation lowers } \\
\text { prop. value }\end{array}$ & 368.5 & 937.9 & 53 \\
\hline $8 / O R / 2000$ & 4 & $\begin{array}{l}\text { limits state spending to fixed } \\
\text { percentage }\end{array}$ & 387.5 & 995.1 & 43.5 \\
\hline 9/OR/2000 & 4 & $\begin{array}{l}\text { public schools cannot encourage } \\
\text { homosexuality }\end{array}$ & 238.3 & 1472.5 & 47.1 \\
\hline
\end{tabular}




\section{- Appendix C - Design \#3 Data}

On the following page, in Table C.1, the county-level data from Design \#3 is displayed. Each county is presented in a separate row alongside its level of Democratic

Party attachment. Columns are presented for each initiative number, state, and year. Then rows show each counties' percentage of Yes vote for a given initiative. 


\begin{tabular}{|c|c|c|c|c|c|c|}
\hline COUNTY & $\begin{array}{l}\text { DEMOCRATIC } \\
\text { AFFILIATION }\end{array}$ & $\begin{array}{l}36 / O R / 20 \\
04\end{array}$ & $\begin{array}{l}37 / \mathrm{OR} / \\
2004\end{array}$ & $\begin{array}{l}35 / \mathrm{OR} / \\
2004\end{array}$ & $\begin{array}{l}\text { 14/OR/ } \\
2004\end{array}$ & $\begin{array}{l}\text { 43/OR/ } \\
2006\end{array}$ \\
\hline BAKER & 29 & 61.3 & 50.7 & 44.9 & 32.6 & 42.7 \\
\hline BENTON & 58 & 36.6 & 38.5 & 25.4 & 69 & 52.1 \\
\hline CLACKAMAS & 48.8 & 49.2 & 51.7 & 35.6 & 64.1 & 46.8 \\
\hline CLATSOP & 54.2 & 44.4 & 41.3 & 35 & 60.6 & 62.6 \\
\hline COLUMBIA & 50.4 & 53.8 & 47.8 & 38.4 & 49.8 & 57.5 \\
\hline coos & 43.1 & 54.3 & 48.4 & 41.2 & 45.1 & 52.1 \\
\hline CROOK & 30.1 & 65.1 & 51 & 46.5 & 42.2 & 52 \\
\hline CURRY & 40.8 & 58 & 47.9 & 45.3 & 46.2 & 53.6 \\
\hline DESCHUTES & 42.1 & 52.4 & 48.5 & 40.1 & 58.4 & 49.1 \\
\hline DOUGLAS & 32.5 & 63.9 & 50.5 & 43.7 & 39.9 & 41.1 \\
\hline GILLIAM & 32.5 & 52.6 & 44.3 & 36.7 & 45.9 & 50.7 \\
\hline GRANT & 19.2 & 64.7 & 53.6 & 43.9 & 22.8 & 49.2 \\
\hline HARNEY & 22.7 & 65.3 & 49.2 & 46.2 & 31 & 44.7 \\
\hline HOOD RIVER & 56.7 & 46.4 & 46.5 & 36.4 & 61.5 & 52.8 \\
\hline JACKSON & 43.4 & 52.4 & 52.5 & 35.5 & 58.2 & 54.7 \\
\hline JEFFERSON & 40 & 55.9 & 48.7 & 41.9 & 51.6 & 50.4 \\
\hline JOSEPHINE & 36 & 62.1 & 49.9 & 43.4 & 49.6 & 46.2 \\
\hline KLAMATH & 26.2 & 62.7 & 48.9 & 46 & 39.6 & 39 \\
\hline LAKE & 20.5 & 66.6 & 51.9 & 45.7 & 29.9 & 41.1 \\
\hline LANE & 58 & 42.4 & 40.8 & 31 & 65.5 & 53.2 \\
\hline LINCOLN & 56.5 & 42.9 & 43.2 & 39.1 & 62.6 & 60.4 \\
\hline LINN & 38.3 & 59 & 50.3 & 38.8 & 47.4 & 46.5 \\
\hline MALHEUR & 23.8 & 67.7 & 59.2 & 50.2 & 31.4 & 39.4 \\
\hline MARION & 44.5 & 51.8 & 51 & 34.3 & 62.5 & 44.2 \\
\hline MORROW & 32.8 & 58.2 & 46.5 & 42.4 & 39.3 & 54.2 \\
\hline MULTNOMAH & 71.6 & 32.8 & 41.6 & 28.5 & 75.5 & 62.3 \\
\hline POLK & 43.6 & 52.2 & 51.7 & 31.5 & 59.9 & 42.9 \\
\hline SHERMAN & 35.3 & 53.5 & 49.7 & 43.2 & 40.8 & 45.2 \\
\hline TILLAMOOK & 48.4 & 49.6 & 45.3 & 39.1 & 56.9 & 53.9 \\
\hline UMATILLA & 33.8 & 58.6 & 44.8 & 39.6 & 44.9 & 50.1 \\
\hline UNION & 32.8 & 55.5 & 46.8 & 38 & 39.7 & 49.7 \\
\hline WALLOWA & 28.1 & 61.9 & 51.9 & 46.5 & 29.2 & 48.5 \\
\hline WASCO & 47.4 & 51.3 & 49.4 & 37.8 & 55.2 & 54.2 \\
\hline WASHINGTON & 52.4 & 44 & 50.9 & 34.1 & 69.1 & 46.9 \\
\hline WHEELER & 27.8 & 64.7 & 46.3 & 42.5 & 30.7 & 49.9 \\
\hline YAMHILL & 40 & 53.9 & 52.3 & 38.4 & 55.9 & 46.3 \\
\hline
\end{tabular}

Figure C.1: County-level Yes voting percentage on initiative and county-level Democratic Party attachmen 
Figure C.1: County-level Yes voting percentage on initiative and county-level Democratic Party affiliation (continued)

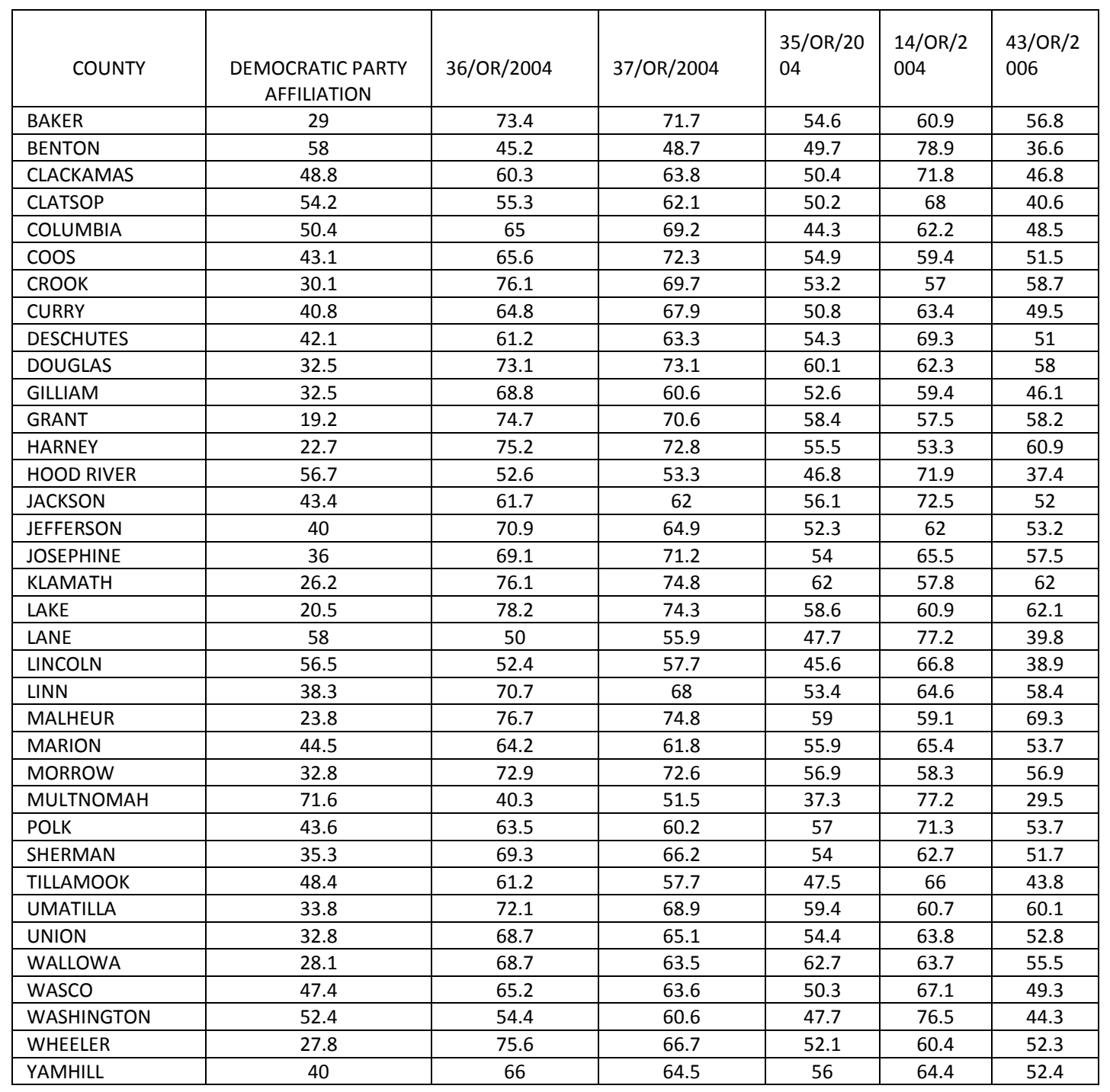


Figure C.1: County-level Yes voting percentage on initiative and county-level Democratic Party affiliation (continued)

\begin{tabular}{|c|c|c|c|c|c|}
\hline COUNTY & $\begin{array}{c}\text { DEMOCRATIC PARTY } \\
\text { AFFILIATION }\end{array}$ & $40 / O R / 2006$ & $48 / O R / 2006$ & $42 / O R / 2006$ & $47 / O R / 2006$ \\
\hline BAKER & 29 & 59.6 & 31.4 & 35.1 & 57.7 \\
\hline BENTON & 58 & 35.1 & 21.8 & 28.7 & 41.6 \\
\hline CLACKAMAS & 48.8 & 43.1 & 33.3 & 35 & 53.2 \\
\hline CLATSOP & 54.2 & 42 & 27.8 & 34.2 & 52.6 \\
\hline COLUMBIA & 50.4 & 51.6 & 32.9 & 38.8 & 57.9 \\
\hline coos & 43.1 & 53.7 & 30.9 & 34.5 & 53.9 \\
\hline CROOK & 30.1 & 59.2 & 37.1 & 36.8 & 61.3 \\
\hline CURRY & 40.8 & 53.4 & 29.9 & 36.2 & 59.8 \\
\hline DESCHUTES & 42.1 & 47.8 & 29.5 & 32.4 & 55.4 \\
\hline DOUGLAS & 32.5 & 57.9 & 35.3 & 37.6 & 55.9 \\
\hline GILLIAM & 32.5 & 59.8 & 23.3 & 43.6 & 54.6 \\
\hline GRANT & 19.2 & 63.5 & 32.9 & 37.9 & 57.5 \\
\hline HARNEY & 22.7 & 64.3 & 34.7 & 43.8 & 57.2 \\
\hline HOOD RIVER & 56.7 & 44.5 & 26.3 & 35 & 54.6 \\
\hline JACKSON & 43.4 & 49.6 & 29.9 & 31.9 & 53.9 \\
\hline JEFFERSON & 40 & 53.8 & 32 & 35.1 & 57.9 \\
\hline JOSEPHINE & 36 & 56.9 & 32.4 & 34.6 & 58.2 \\
\hline KLAMATH & 26.2 & 67.5 & 37.5 & 40.9 & 59 \\
\hline LAKE & 20.5 & 68.6 & 33.3 & 41.9 & 56.9 \\
\hline LANE & 58 & 38 & 23.9 & 34.8 & 51.2 \\
\hline LINCOLN & 56.5 & 45.7 & 28.8 & 38.4 & 59.8 \\
\hline LINN & 38.3 & 53.9 & 34.9 & 37.1 & 55.9 \\
\hline MALHEUR & 23.8 & 66 & 33.7 & 42 & 55.6 \\
\hline MARION & 44.5 & 46.2 & 33.5 & 34.4 & 53.5 \\
\hline MORROW & 32.8 & 62.8 & 30.7 & 41.5 & 59.2 \\
\hline MULTNOMAH & 71.6 & 30 & 22.9 & 37.3 & 50 \\
\hline POLK & 43.6 & 47.6 & 32.8 & 31.9 & 54.1 \\
\hline SHERMAN & 35.3 & 66 & 32.5 & 43.7 & 61.2 \\
\hline TILLAMOOK & 48.4 & 49.1 & 29.7 & 38.9 & 57.3 \\
\hline UMATILLA & 33.8 & 58.4 & 31.1 & 42.5 & 56.6 \\
\hline UNION & 32.8 & 57.1 & 27 & 30.4 & 54 \\
\hline WALLOWA & 28.1 & 59.8 & 30.7 & 34.8 & 52.7 \\
\hline WASCO & 47.4 & 54.8 & 29.9 & 39.8 & 58.4 \\
\hline WASHINGTON & 52.4 & 38.9 & 30 & 34.4 & 52.2 \\
\hline WHEELER & 27.8 & 63.2 & 28.6 & 41.2 & 56.6 \\
\hline YAMHILL & 40 & 48.3 & 33.8 & 35.4 & 54.5 \\
\hline
\end{tabular}

